\title{
From Paradox to Subsidiarity: The United States and Human Rights Treaty Bodies
}

\author{
Tara J. Melish ${ }^{\dagger}$
}

I. INTRODUCTION 390

II. Legal Context: The Human Rights Framework Applicable to the United States ....... 395

III. SUPERVISORY TREATY BODY SYSTEM AND THE SCOPE OF U.S. ENGAGEMENT ........................... 404

A. Periodic Reporting Process .......................................................................................405

B. Individual and Collective Complaint Procedures and Precautionary Measures .............410

C. Other Promotional Mechanisms ..............................................................................415

IV. INTEREST Management: The PUSh-PULl of Domestic ANd Foreign Policy Agendas ....... 416

A. Foreign Policy Interests: Net Push Toward Greater Treaty Body Engagement ..............417

B. Domestic Policy Interests: From Net Pull to Push, the Evolution of Domestic

Social Struggles ............................................................................................................421

1. Diminishing U.S. Receptivity to Insulationism .............................................424

2. Creeping Incorporation, Despite Insulationist Obstruction .................................427

3. Responding to Incorporation's Advances: Reappropriating Rights.....................431

V. Mediating Techniques for Promoting U.S. Engagement: Asserting Clear

JURISDICTIONAL LINES AND RECURRING (SELECTIVELY) TO SUBSIDIARITY DOCTRINE.

A. Sovereignty-Based Mediating Techniques: Carving Out "No Go" Zones in Treaty

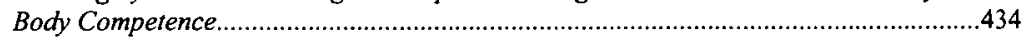

B. Subsidiarity-Based Mediating Techniques: Emphasizing Doctrines of Deference to Domestic Political Process ............................................................................................438 1. Preferring "Political" to "Judicial" Controls in Human Rights Supervision and Interpretation ...................................................................440

2. Retaining Full Remedial and Policymaking Discretion ..................................443

C. Mediation Through Jurisdictional Aggressiveness.........................................................444

VI. WheRE FROM HERE?: STRATEGIC INSIGHTS FROM AN INTEREST-MEDIATION PERSPECTIVE ON U.S.

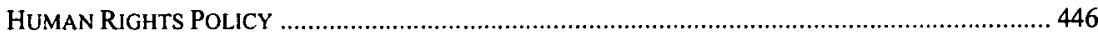

A. The Shape of U.S. Engagement Policy Toward the Future .........................................446

B. The Democratic Dangers of Exceptionalist Narrative ..................................................449

C. Rethinking Incorporationist Strategy ........................................................................450

VII. HONORING SUBSIDIARITY DOCTRINE IN FULL: FROM INTERNATIONAL DEFENSE TO DOMESTIC

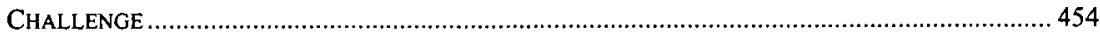

A. National Office on Human Rights Implementation and Interagency Coordination

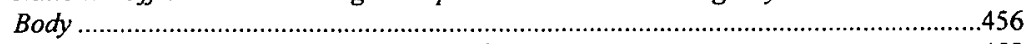

B. United States Commission on Human Rights ..............................................................458

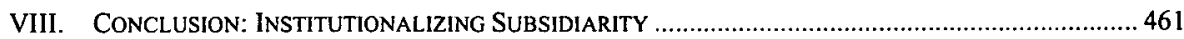

$\dagger \quad$ Visiting Professor, University of Notre Dame School of Law, Spring 2009. Associate Professor of Law, University at Buffalo School of Law, SUNY. Yale Law School, J.D. 2000; Brown University, B.A. 1996. Special thanks are owed to Robert K. Harris, Steven R. Hill, and Mark P. Lagon of the U.S. Department of State for their helpful conversations on issues discussed herein; to Professors Sean Murphy, Susan Benesch, Rick Wilson, and Cesare Romano for their valuable comments on an earlier draft; and to $Y J I L$ for excellent editorial suggestions. All views and errors remain exclusively my own. 


\section{In the battle for democracy and human rights, words matter, but what we do matters much more. \\ -Warren Christopher ${ }^{1}$}

\section{INTRODUCTION}

It is frequently said that the United States has a paradoxical human rights policy. ${ }^{2}$ On the one hand, the United States embraces human rights principles as a founding national ideology, ${ }^{3}$ and has supported the enhancement of human rights and democracy as a core premise of its foreign policy since the end of the Second World War, when it played a leading role in birthing the international human rights regime. ${ }^{4}$ Indeed, the promotion of human rights and democracy abroad is a central motivating tenet of U.S. foreign policy, manifested in the nation's extensive foreign assistance commitments, political and financial support of international human rights bodies, linking of bilateral aid to human rights improvements, and annual reporting on the human rights situation of 194 nations of the world. ${ }^{5}$ National public opinion polls, moreover, suggest that roughly eighty percent of Americans believe that human rights inhere in every human being. ${ }^{6}$ Equal numbers express not only their support for U.S. ratification of human rights treaties, but also their belief that international supervision over those treaty commitments, by a court or other independent body, is necessary. ${ }^{7}$

1. Warren Christopher, U.S. Sec'y of State, Democracy and Human Rights: Where America Stands, Address to 1993 World Conference on Human Rights (June 14, 1993), in 4 U.S. STATE DEP'T DiSPATCH No. 25 (June 23, 1993).

2. See, e.g., Andrew Moravcsik, The Paradox of U.S. Human Rights Policy, in AMERICAN EXCEPTIONALISM AND HUMAN RighTS 147 (Michael Ignatieff ed., 2005).

3. See, e.g., U.S. DeP'T OF STATE, Fundamentals OF U.S. Foreign Policy 24 (1988) ("The cause of human rights forms the core of American foreign policy [as] it is central to America's conception of itself."); Christopher, supra note 1 ("America's identity as a nation derives from our dedication to the proposition 'that all Men are created equal and endowed by their Creator with certain unalienable Rights."' (quoting THE DECLARATION OF INDEPENDENCE para. 2 (U.S. 1776)).

4. See mary ann Glendon, a World Made New: Eleanor Roosevelt and the UniVersal Declaration of Human Rights (2001).

5. The U.S. Department of State, under congressional mandate, has been reporting annually on human rights conditions in countries around the world since 1976. Since 2002, these Country Reports on Human Rights Practices have been supplemented by an annual report to Congress on the specific actions taken by the U.S. government to encourage respect for human rights around the world, in compliance with section 665 of the Foreign Relations Authorization Act, Fiscal Year 2003, Pub. L. No. 107-228, 116 Stat. 1350 (codified as amended at 22 U.S.C. $\S \S 215 \ln , 2304$ (2000 \& Supp. VII 2007)). See, e.g., U.S. DEP'T OF STATE, SUPPORTING HUMAN RIGHTS AND DEMOCRACY: THE U.S. RECORD 2006 (2006), available at http://www.state.gov/documents/organization/80699.pdf. Of course, U.S. foreign policy has also served over the years to consolidate the power of many dictators and repressive governments responsible for systematic human rights abuse.

6. See Belden RuSSONello \& STEWART, Human Rights IN THE United States: Findings FROM A NATIONAL SURVEY 12 (2007) (noting that such belief obtains whether or not the government ratifies human rights treaties).

7. See, e.g., Steven Kull et al., americans on International Courts and Their JURISDICTION OVER THE U.S. 3 (2006), available at http://www.worldpublicopinion.org/pipa/pdf/may06/ Tribunals_May06_rpt.pdf. The poll finds that seventy-nine percent of Americans believe that there should be an independent international body, such as a court, to judge whether the United States and other states parties are abiding by the international human rights treaties they ratify. Indeed, of all subject matters commonly governed by treaty (e.g., border disputes, fishing rights, environment, human 
Yet, despite strong external and internal human rights commitments, the United States has appeared to flinch, even recoil, when it comes to direct domestic application of human rights treaty norms, especially as those norms are interpreted by international supervisory bodies. Whether through the executive, legislature, or the courts, the nation has insisted that human rights treaties are non-self-executing domestically and has remained ambivalent toward international adjudicatory fora that may judge it on its own human rights treaty commitments. ${ }^{8}$ The United States has renounced international bodies that have issued judgments against it on human rights matters, ${ }^{9}$ declined to affirmatively accept the contentious jurisdiction of human rights bodies, ${ }^{10}$ and even fought the creation of new international bodies with adjudicatory competence over its citizens. ${ }^{11}$ It is this apparent paradox of U.S. human rights policy-outwardly prodigious, inwardly niggardly-and its underlying set of "antinomies" 12 that a growing literature has sought to document and explain, often through the lens of U.S. exceptionalism. ${ }^{13}$

This Article offers a new narrative based in interest-group management. It does so by taking a closer look at the U.S. human rights paradox from the perspective of U.S. engagement with international human rights treaty bodies. ${ }^{14}$ This engagement, once negligible, has expanded quite significantly over the last decade, a byproduct of the United States's careful navigation through a diverse set of political pressures. It is thus useful to view the distinct ways and degrees in which this engagement manifests itself, especially with respect to the varied competences treaty bodies exercise along the supervisory spectrum. Doing so allows us to take a closer look at the actual reasons why the United States may shrink from full engagement with certain international processes, while accepting others fully. Such a frame can, in turn, reveal important insights for predicting what the United States can and will do in the future, why, and under what preconditions or constraining guidelines. Importantly, it also allows us to begin to imagine a set of institutional arrangements and coordinating mechanisms that can help to address the dominant underlying concerns, particularly as they relate to recurrently raised federalism, separation of powers, and countermajoritarian objections.

rights, trade, labor, investments, and protection of aliens), human rights received the highest percentage of support for the proposition that independent international tribunal supervision over corresponding treaty compliance was necessary. Id.

8. See, e.g., Medellín v. Texas, 128 S. Ct. 1346 (2008).

9. See, e.g., infra note 213 .

10. See infra Section III.B.

11. See, e.g., infra note 212 .

12. See Sean D. Murphy, The United States and the International Court of Justice: Coping with Antinomies, in THE SwORD AND the SCALES: THE UNITED STATES AND INTERNATIONAL COURTS AND TRIBUNALS (Cesare Romano ed., forthcoming 2009), available at http://ssm.com/abstract=100039 (defining antinomies as "equally rational but conflicting principles" and discussing three that underlie U.S. foreign policy: realism vs. institutionalism; exceptionalism vs. sovereign equality; and autonomous national law vs. internationally embedded domestic law).

13. See, in particular, contributions in AMERICAN EXCEPTIONALISM AND HUMAN RIGHTS, supra note 2 .

14. Human rights treaty bodies refer to the committees or commissions of independent experts set up under key human rights treaties to supervise, through quasi-adjudicatory and promotional powers, state-party compliance with treaty undertakings. 
My central claim is that a closer, more searching look at the nature and scope of U.S. treaty body engagement policy-especially at the plurality of disaggregated policy interests that determine its evolving and often asymmetric contours-reveals that the U.S. human rights paradox may not in fact be so paradoxical. To the contrary, given U.S. engagement policy's modern doctrinal anchoring in one of international human rights law's most foundational principles - the principle of subsidiarity ${ }^{15}$ - it may be precisely the foundation necessary to build a strong and sustainable domestic human rights policy over the long term. Achieving this, however, will require a fundamental shift in thinking and strategy among many domestic advocates. That shift is one which draws from the insights of an interest-mediation perspective to transform the current U.S. engagement emphasis on the negative dimension of the subsidiarity principle from a shield into a sword. That is, the tools of the subsidiarity principle must not be permitted to be used only defensively by U.S. actors to shield domestic legislative and judicial processes from international intervention. They must also be used offensively to routinize, within the bounds of U.S. federalism, an internal process of domestic self-reflection and localized democratic deliberation on how we, in our own local communities, wish to protect internationally recognized human rights to best ensure the dignity of the human person.

The challenge for domestic human rights advocates, I argue, is not to reject the negative dimensions of subsidiarity (as is the tendency today), dimensions which are core to U.S. interest-management techniques, but rather to firmly embrace them, while likewise finding new ways of working flexibly and effectively within the subsidiarity paradigm to institutionalize a framework for respecting the positive half. In this way, advocates may ensure that U.S. engagement policy is directed not only outward, toward an international audience, but, just as critically, inward to our own domestic constituencies. It is this vital shift in U.S. human rights policy-from partial subsidiarity (paradox) to genuine subsidiarity-that is the focus of this Article.

Yet a doctrinally anchored, interest-mediation perspective on U.S. human rights policy does not only help to chart a path toward the future. It also helps to explain the present and past. It offers, in this regard, a fuller, more empirically plausible and realistic account of U.S. human rights policy than can parallel accounts sounding in "U.S. exceptionalism," whether of a "rights cultural" or "structural" variety. ${ }^{16}$ Indeed, a closer look at the actual ways in which the United States engages with human rights treaty bodies-

15. The principle of subsidiarity, discussed more fully in Parts V and VI below, governs the appropriate relationship between international, national, and subnational supervision in the shared project of ensuring human rights protection for all individuals. Foundational to international human rights law, it has been broadly defined as "the principle that each social and political group should help smaller or more local ones accomplish their respective ends without, however, arrogating those tasks to itself." Paolo G. Carozza, Subsidiarity as a Structural Principle of International Human Rights Law, 97 AM. J. INT'L L. 38, $38 \mathrm{n} .1$ (2003) (providing a "simplified working definition").

16. See Moravcsik, supra note 2 (discussing "rights cultural" and "structural" narratives of U.S. exceptionalism, while defending the latter). 
and, specifically, at the varying mediating techniques ${ }^{17}$ it employs to ensure its engagement comports with evolving U.S. domestic and foreign policy interests-suggests that academic prognostications that the United States will resist further engagement with human rights bodies are shortsighted. While prominent observers of the "U.S. human rights paradox" have suggested that we should not be optimistic about further U.S. engagement in the international human rights regime, given certain structural conditions that set the United States apart from other nations, ${ }^{18} \mathrm{I}$ argue that this view may be overly static in its portrayal of the predicted behavior of relevant social actors, even under unreservedly correct "thicker" explanations of U.S. ambivalence to human rights law. ${ }^{19}$ Specifically, while correctly focusing on domestic special interest politics and the unique ability of veto players in the nation's highly decentralized and fragmented political structure to block treaty ratification notwithstanding supportive domestic majorities (especially under Republican Senate majorities), such a view fails to take account of the diverse and dynamic ways that civil society advocates - of both liberal and conservative persuasions - take advantage of changing positions and new strategic openings for advancing their substantive policy preferences.

In particular, by focusing too narrowly on conservative politics, veto players, and formal treaty ratification procedures at the domestic level, the view fails to take account of the equally relevant strategies and campaigns of liberal politics, including their regular employ of the many "deblocking" opportunities presented by the fragmented U.S. political structure. Likewise, it insufficiently addresses the critical ways that the U.S. government acts in a mediating role between each of these countervailing persuasions, including those operating at the foreign policy level: bowing more or less to one or the

17. The term "mediating techniques" is used here in relation to the tactics, methods, and postures employed by the U.S. government in modulating its human rights engagement policy to take into account the countervailing pressures faced from a diversity of interest groups, at both domestic and foreign policy levels, each urging greater or lesser levels of U.S. engagement. This usage differs slightly from the term's primary use in the scholarly literature to describe the justiciability doctrines and other techniques of judicial restraint used by courts and tribunals, at both national and international levels, to accommodate separation of powers, federalism, subsidiarity, and sovereignty concerns. See, e.g., Alexander M. Bickel, The Least Dangerous Branch 111-12 (Yale Univ. Press 1982) (1962) (discussing domestic judiciary's "passive virtues" and quoting Justice Brandeis's assertion that the "mediating techniques of "not doing"" were the most important thing the U.S. Supreme Court did); Murphy, supra note 12 (discussing and citing other scholarly discussions of "mediating techniques" used by international tribunals to promote engagement by States).

18. See Moravcsik, supra note 2. Moravcsik identifies four such structural conditions (external power, democratic stability, conservative minorities, and fragmented political institutions that empower small veto groups), concluding that "the United States is exceptional primarily because it occupies an extreme position in [these] four structural dimensions of human rights politics, from which we would expect extreme behavior on the part of any government." Id. at 150-51. He nonetheless draws a surprising, seemingly unwarranted conclusion from this: "U.S. ambivalence toward international human rights commitments" is so "woven into the deep structural reality of American political life" that absent "an epochal constitutional rupture ... it is unlikely to change anytime soon." Id. at 197 (emphasis added).

19. See id. at 152-92 (arguing convincingly that a "thicker," "pluralist" explanation that focuses on the instrumentality of partisan politics and conservative policy agendas in explaining U.S. human rights behavior is more plausible empirically than "thinner" accounts that attribute U.S. ambivalence to a unique American "rights culture," one predisposing Americans to oppose human rights treaty commitments). 
other with evolving policy priorities, yet always within the bounds of a principled, rule-bound policy position. Under this light, any prediction that the United States will not further engage with human rights treaty bodies may be missing critical domestic movements and changing visions of political agency that suggest the contrary.

This is particularly true as advocates and interest groups adapt their strategies to the hard reality of U.S. ratification of an increasing number of human rights treaties and persistent engagement with international supervisory procedures. The fundamental domestic debate has in many ways thus changed. It is no longer whether the United States will ratify human rights treaties, but rather how domestic advocates will use U.S. ratification and international engagement to achieve their distinct policy agendas and what measures or methodologies the U.S. government will adopt to mediate these countervailing pressures.

To address these important issues, this Article proceeds in eight parts. Part II provides an overview of the legal framework that structures current U.S. human rights treaty body engagements at the national and international levels. Part III supplements this review by examining the specific ways that the United States ${ }^{20}$ in fact engages with the three principal competences exercised by the United Nations, Organization of American States (OAS), and International Labour Organization (ILO) supervisory treaty body systems: periodic reporting, quasi-adjudication, and promotional activities. It concludes that U.S. engagement with these competences is in fact far more robust than popular notions of the "U.S. human rights paradox" would suggest.

Part IV seeks then to explain this discrepancy. It suggests that U.S. engagement policy is best viewed not as a static or structural given, but rather as a complex mediation between a variety of pressures exerted on policymakers by powerful actors at both the foreign and domestic policy levels. Disaggregating those pressures, the analysis emphasizes the role of four distinct groups that contribute to the pragmatic calculus undertaken in shaping U.S. human rights policy. These include "realists" and "institutionalists" at the foreign policy level, and groups I call "insulationists" and "incorporationists" at the domestic policy level, each seeking alternately greater or lesser substantive and procedural engagement with human rights bodies, in accordance with their group-specific policy interests. While scholars in the various camps of international relations theory tend to explain U.S. engagement policy with primary emphasis on one of these four groups, ${ }^{21}$

20. Throughout this Article, "United States" is used to refer to the state agents that express the policy position of the state before international treaty bodies. While frequently represented by the U.S. State Department, positions asserted by the "United States" are often informed by many complex processes.

21. These camps include those dedicated to realism, institutionalism, liberalism, and constructivism. For a general descriptive overview, see Oona A. Hathaway, Do Human Rights Treaties Make a Difference?, 111 YALE L.J. 1935 (2002). Though neither liberalism nor constructivism refers in name to "insulationists" or "incorporationists," liberalism's emphasis on domestic political structures and processes focuses it on the veto-player politics of the former, just as constructivism's privileging of the role of nonstate actors and their persuasive discourses focuses it on the tactics and strategies of the latter. 
it is the complex interaction and competing interests of each of them, I argue, that determines the precise coordinates at which U.S. policy can most accurately be mapped.

To explain how this complex management process is effectuated, Part V identifies the five principal mediating techniques employed by the United States in its current treaty body engagements, each designed to accommodate distinct sets of competing interest-group pressures. While each of these mediating techniques is solidly anchored in foundational international law doctrines of sovereignty and subsidiarity, each nonetheless draws on only the negative dimensions of those doctrines. Corresponding to doctrines of noninterference and deference to domestic political processes, this selective posture allows the United States to effectively manage competing interestgroup pressures, pursuing an engagement policy that at once bows to foreign policy interests to engage (within certain jurisdictional limits), attends to domestic democracy-based oppositional concerns, and opens a space in which domestic human rights advocates can pursue a politically based incorporationist agenda. How domestic incorporationists use this space, I argue, will determine the future shape of U.S. human rights policy.

In this regard, Part VI turns to a set of strategic insights that an interestmediation perspective on U.S. human rights policy provides for thinking about the nature and scope of U.S. human rights policy toward the future and, most importantly, the agency and opportunities of distinct actors in affecting it. Specifically, it suggests a concrete set of postures for advocates of greater domestic human rights attention to adopt toward the future, postures which draw directly on the positive dimensions of the subsidiarity project. Indeed, whether human rights treaty law becomes a more permanent fixture in U.S. law and policymaking in the coming years will depend in large measure on the extent to which this positive dimension of the subsidiarity principle is constructively embraced by U.S. policymakers and, most importantly, by domestic human rights advocates-actively employed to formalize and institutionalize domestic supervisory and monitoring processes, at local, state, and federal levels, as a national project (rather than international one). ${ }^{22}$ An outline of how this might be institutionally pursued and structured in the United States is discussed in Part VII. Part VIII concludes.

\section{LEGAL CONTEXT: THE HUMAN RIGHTS FRAMEWORK APPLICABLE TO THE UNITED STATES}

It is frequently contended that the United States ratifies few international human rights treaties. While this may be true in relative terms, it does not fairly represent the scope of commitments the United States has in fact undertaken under international human rights law, particularly over the last two decades. Under growing pressure from domestic and international constituents

22. It has been observed, for example, that "from a Liberal perspective, $a$-if not the-primary function of public international law is . . . to influence and improve the functioning of domestic institutions" and that, accordingly, "human rights law is the core of international law." Anne-Marie Slaughter, A Liberal Theory of International Law, 94 AM. SOC'Y INT'L L. PROC. 240, 246 (2000). 
and with strong bipartisan support, the United States has ratified an increasingly broad spectrum of human rights treaties, under Republican and Democratic administrations alike. Thus, under the administrations of George H.W. Bush, William J. Clinton, and George W. Bush, the United States has ratified the International Covenant on Civil and Political Rights (ICCPR), ${ }^{23}$ the Convention Against Torture and Other Cruel, Inhuman or Degrading Treatment or Punishment (CAT) ${ }^{24}$ the International Convention on the Elimination of All Forms of Racial Discrimination (CERD),${ }^{25}$ the Convention on the Prevention and Punishment of the Crime of Genocide, ${ }^{26}$ a series of ILO treaties on labor rights, ${ }^{27}$ and the Optional Protocols to the Convention on the Rights of the Child on the Involvement of Children in Armed Conflict and on the Sale of Children, Child Prostitution, and Child Pornography. ${ }^{28}$ The United States has also ratified human rights treaties relating to slavery, ${ }^{29}$ refugees, ${ }^{30}$ and the political rights of women, ${ }^{31}$ among others, ${ }^{32}$ and has ratified the OAS Charter, which subjects it to the quasi-judicial jurisdiction of the Inter-

23. International Covenant on Civil and Political Rights, Dec. 16, 1966, S. ExEc. Doc. E, $95-$ 2 (1978), 999 U.N.T.S. 171 [hereinafter ICCPR]. The ICCPR was ratified by the United States on June $8,1992$.

24. Convention Against Torture and Other Cruel, Inhuman or Degrading Treatment or Punishment, Dec. 10, 1984, S. TREATY DoC. No. 100-20 (1988), 1465 U.N.T.S. 85 [hereinafter CAT]. The CAT was ratified by the United States on October 21, 1994.

25. International Convention on the Elimination of All Forms of Racial Discrimination, Dec. 21, 1965, S. EXEC. Doc. C, 95-2 (1978), 660 U.N.T.S. 195, 212 [hereinafter CERD]. The CERD was ratified by the United States on October 21, 1994.

26. Convention on the Prevention and Punishment of the Crime of Genocide, Dec. 9, 1948, 102 Stat. 3045, 78 U.N.T.S. 277. The Convention was ratified by the United States on November 25, 1988.

27. See, e.g., Convention Concerning the Abolition of Forced Labour, June 25, 1957, S. TREATY DOC. 88-11, 320 U.N.T.S. 291 (ratified by the United States on September 25, 1991); Convention Concerning the Prohibition and Immediate Action for the Elimination of the Worst Forms of Child Labour, June 17, 1999, 2133 U.N.T.S. 161 (ratified by the United States on December 2, 1999). As of 2008, the United States has ratified a total of fourteen ILO treaties.

28. Optional Protocol to the Convention on the Rights of the Child on the Involvement of Children in Armed Conflict, May 25, 2000, 2173 U.N.T.S. 222 (ratified by the United States on December 23, 2002); Optional Protocol to the Convention on the Rights of the Child on the Sale of Children, Child Prostitution and Child Pornography, G.A. Res. 54/263, Annex II, at 6, 54 U.N. GAOR, Supp. No. 49, U.N. Doc. A/54/49 (2000) (ratified by the United States on December 23, 2002).

29. See, e.g., Slavery, Servitude, Forced Labour and Similar Institutions and Practices Convention of 1926, Sept. 25, 1926, 46 Stat. 2183, 60 L.N.T.S. 253; Protocol Amending the Slavery Convention, Dec. 7, 1953, 7 U.S.T. 479, 182 U.N.T.S. 51; Supplementary Convention on the Abolition of Slavery, the Slave Trade and Institutions and Practices Similar to Slavery, Sept. 7, 1956, 226 U.N.T.S. 3.

267.

30. Protocol Relating to the Status of Refugees, Oct. 4, 1967, 19 U.S.T. 6223, 606 U.N.T.S.

31. Convention on the Political Rights of Women, July 7, 1954, 27 U.S.T. 1909, 193 U.N.T.S. 135; Inter-American Convention on the Granting of Political Rights to Women, May 2, 1948, O.A.S. T.S. No. 3 (ratified by the United States on March 22, 1976).

32. The United States has ratified all four Geneva Conventions. It has also "entered into many bilateral treaties (including consular treaties and treaties of friendship, commerce and navigation) that contain provisions guaranteeing rights to nationals of foreign countries on a reciprocal basis," some of which may be invoked directly in U.S. courts. Office of the U.N. High Comm'r for Human Rights, Core Document Forming Part of the Reports of States Parties: United States, I 151, U.N. Doc. HRI/CORE/USA/2005 (Jan. 16, 2006). 
American Commission on Human Rights with respect to the rights enshrined in the American Declaration on the Rights and Duties of Man. ${ }^{33}$

Taken together, these treaties cover a vast spectrum of rights-of a civil, cultural, economic, political, and social nature - and extend horizontally under three distinct supranational supervisory systems, each with its own set of promotional and quasi-adjudicatory powers. In this sense, while critical attention is often focused on the U.S. failure to ratify certain internationally popular treaties, including the Convention on the Rights of the Child (CRC), the Convention on the Elimination of All Forms of Discrimination Against Women (CEDAW), the American Convention on Human Rights, and the International Covenant on Economic, Social and Cultural Rights (ICESCR), it must be recognized that the scope of international commitments implicated by these treaties has already, in large measure, been undertaken by the United States pursuant to the treaties that it has ratified. ${ }^{34}$ This reality complicates the utility for partisan actors of wholesale opposition to currently nonratified treaties. It also undermines claims that the United States fails to ratify human rights treaties out of a cultural commitment to "negative" or libertarian conceptions of rights or a cultural aversion to economic, social, and cultural rights, two frequently raised but factually uncompelling explanations. ${ }^{35}$ These are pretexts for other interests at play. ${ }^{36}$ Indeed, in its interactions with international treaty bodies, the United States regularly addresses the "positive" dimensions of its human rights obligations as well as a wide spectrum of economic, social, and, cultural rights, ${ }^{37}$ as it does in its own domestic legislation.

33. See infra notes 108-109.

34. There is indeed wide overlap in the rights protected in distinct human rights treaties. CEDAW, CRC, and ICESCR subject matters are thus regularly taken up through ICCPR, CERD, CAT, and ILO convention supervisory procedures.

35. See Moravcsik, supra note 2, at 163 . While Moravcsik rejects cultural aversion to social rights as a credible reason for U.S. ambivalence to human rights, he nonetheless does so on the questionable ground that the United States could simply choose to ratify civil and political rights treaties while ignoring socioeconomic ones. Id. This view not only ignores the substantial overlap of subject matters in human rights treaties, see Airey v. Ireland, 32 Eur. Ct. H.R. (ser. A) at 12 (1979) (noting "no water-tight division" separating social rights and guaranteed civil and political rights), but also the significant embrace of social rights as human rights by U.S. majorities and legislatures. A 2007 national survey found that strong majorities of Americans not only believe but "strongly believe" that a core set of social rights are human rights. These include equal access to quality public education ( $82 \%)$; access to healthcare $(72 \%)$; living in a clean environment $(68 \%)$; fair pay for workers to meet the basic needs for food and housing $(68 \%)$; freedom from extreme poverty $(52 \%)$; and adequate housing $(51 \%)$. See Belden Russonello \& STEWART, supra note 6, at 3-4; see also CASS R. SUNSTEIN, THE SECOND BILL OF RighTS: FDR'S UNFINISHED REVOLUTION AND WHY WE NEED IT MORE THAN EVER 62-63 (2004) (mentioning similar surveys from the 1990s).

36. This is not to say that those who perpetuate these claims as part of a cultural myth of America are using them as pretext, but rather that their underlying motivations rest on politicalideological foundations of a more partisan nature. See infra Section IV.B.

37. See, e.g., U.S. STATE DEP'T, PERIODIC REPORT OF THE UNITED STATES OF AMERICA TO THE U.N. COMMITTEE ON THE ElIMINATION OF RACIAL DISCRIMINATION CONCERNING THE INTERNATIONAL CONVENTION ON the Elimination of All Forms of RACIAL Discrimination paras. 219-78 (2007), available at $\mathrm{http}: / / \mathrm{www} . s t a t e . g o v / g / d r l / r l s / c e r d \_r e p o r t / 83404 . h t m$ [hereinafter U.S. CERD Report 2007] (addressing the right to work; the right to form and join trade unions; the right to housing; the right to public health, medical care, social security and social services; the right to education and training; and the right to equal participation in cultural activities). 
In this regard, it is also useful to note that while the United States has been slow to ratify many treaties-due primarily to the blocking opportunities presented by the fragmentation of the U.S. political structure-virtually all core human rights treaties have, since the late 1970 s, been signed by the U.S. executive, indicating at least a political commitment to the rights and obligations enshrined therein and a present, if revocable, intent to be bound in the future. ${ }^{38}$ President Carter signed the ICESCR, ICCPR, CERD, and the American Convention in 1977 and CEDAW in 1980. President Reagan signed the Genocide Convention in 1986, and President Clinton signed the CRC and its two Optional Protocols in 1995 and 2000, respectively.

Likewise, the administration of George H.W. Bush presided over U.S. ratification of the ICCPR in 1992, having urged Senate consent in 1991, while President Clinton, who presided over U.S. ratification of the CERD and CAT in 1994 and the ILO Convention 182 in 1999, strongly promoted U.S. ratification of the ICESCR, CEDAW, and CRC from the beginning of his administration in $1993 .{ }^{39}$ The administration of George W. Bush, moreover, not only presided over the ratification of the two optional protocols to the CRC in 2002, but, after an initial decision to step back from the negotiation process, reinitiated active engagement in the final stages of the substantive drafting of the newly adopted U.N. Convention on the Rights of Persons with Disabilities. ${ }^{40}$ It did so under active pressure from both domestic constituencies $^{41}$ and members of the U.S. House of Representatives. ${ }^{42}$

38. Vienna Convention on the Law of Treaties art. 18, opened for signature May 23, 1969, 1155 U.N.T.S. 331, 8 I.L.M. 679 (1969) (stating that a signature obliges certain conduct until a State's intention not to ratify is made clear). In 2002 the Bush administration "unsigned" a treaty to indicate its lack of both obligations thereunder and intent to ratify. See Edward Swaine, Unsigning, 55 STAN. L. REV. 2061 (2003).

39. See, e.g., Christopher, supra note 1 , at 1 . There is wide recognition that Senate consent failed due to the Republican takeover of Congress in 1994.

40. Convention on the Rights of Persons with Disabilities art. 5, opened for signature Mar. 30, 2007, G.A. Res. 61/106, U.N. Doc. A/RES/61/106 (Dec. 6, 2006) [hereinafter Disability Convention]. The Disability Convention received eighty-four signatures on the opening day, more than any human rights treaty in history. Although the United States formally participated in all eight negotiating sessions, it announced its intention not to ratify at the second session in June 2003. See Ralph F. Boyd, U.S. Assistant Att'y Gen. for Civil Rights, Statement to the Second Session of the U.N. Ad Hoc Committee on a Comprehensive and Integral International Convention on Protection and Promotion of the Rights of Persons with Disabilities (June 18, 2003), available at http://www.un.org/esa/socdev/ enable/rights/contrib-us.htm [hereinafter Boyd Statement]. The U.S. delegation thereafter ceased to make substantive proposals, reinitiating its active engagement in the drafting process only at the seventh session in January 2006.

41. See infra Subsection IV.B.3.

42. See H.R. Con. Res. 134, 109th Cong. (2005) (expressing the sense of Congress that the United States should support a U.N. convention on disability rights and thereby urging both "(1) the United States [to] play a leading role in the drafting and adoption of a thematic United Nations convention that affirms the human rights and dignity of persons with disabilities [and] (2) the ... President [to] instruct the Secretary of State to send to the United Nations Ad Hoc Committee meetings a United States delegation that includes individuals with disabilities who are recognized leaders in the U.S. disability rights movement" (emphasis added)). The Resolution was unanimously adopted by the House Committee on International Relations in 2004, but failed to be scheduled for a vote on the House floor by Majority Leader Tom DeLay. Members of the House Committee, together with the Congressional Human Rights Caucus, met directly with members of the U.S. State Department to express their sense of urgency that the United States reinitiate a leadership role in the Disability Convention drafting process, given the United States's historic role in advancing disability rights. 
CEDAW, for its part, has consistently garnered strong, even bipartisan, support in Congress, with Senate Democratic leaders committing in 2008 to bring it to a full Senate vote as soon as politically opportune. Although likely to face intense targeted opposition from anti-abortion lobbies, which by continuing to politicize it in absolutist terms may succeed in blocking it still, it is expected to receive supermajority support.

This treaty-related behavior, from Republican and Democratic administrations alike, suggests two important conclusions. First, it suggests that, despite popular rhetoric to the contrary, the United States does not in principle perceive inherent contradictions between such regimes and U.S. domestic law, policy, or interests. If it did, such treaties would neither be signed by the President nor ratified by Senate supermajorities. Second, given the established track record of speedy human rights treaty ratification with Democratic control of the Senate and Executive, it can be concluded that the nation's political branches reasonably anticipate being subject to human rights treaty regimes as an inevitable outcome of swings in the political process. ${ }^{43}$ Within this context, any view that says that the United States institutionally or "culturally" resists human rights commitments appears incomplete.

The better explanation, as advanced by Professor Moravcsik, rests in the distinct ways that conservative special interest groups exert their influence over veto players in the ratification process, particularly within the U.S. Senate. ${ }^{44}$ Through rhetorical resort to stereotypes and "rights absolutism" 45 that portray international procedures as undemocratic, authoritarian, communistic, and hence "anti-American," these interest groups have historically succeeded in turning the rhetorical debate into one related to American rights culture and states' rights, rather than simply as a rough-andtumble domestic wrestling match over the shape of distinct social policy outcomes, within the methodological framework of human rights commitments and supervisory monitoring procedures. This "thicker" explanation should not, however, lead to dire predictions that the status quo will persist, ${ }^{46}$ but rather to a more searching look at what special interest

43. Strong Democratic control of the Senate has historically been an important facilitating condition for the ratification of human rights treaties. Moravscik calls it a "necessary condition" based on a review of a set of core treaties ratified from 1945 to 2000. See Moravcsik, supra note 2, at 184 ("TThe Senate has never ratified an international human rights treaty (even with reservations) when Democrats held fewer than 55 seats."). It is important to recall, however, that ILO Convention 182 and the two CRC optional protocols were ratified under Republican Senate majorities in 1999 and 2002, respectively.

44. Id. at 186-87 (noting that "[a]11 other things equal, the greater the number of 'veto players,' as political scientists refer to those who can impede or block a particular government action, the more difficult it is for a national government to accept international obligations," and highlighting three characteristics of the U.S. political system that engender veto players: "supermajoritarian voting rules and the committee structure of the Senate, federalism, and the salient role of the judiciary in adjudicating questions of human rights").

45. Rights absolutism can be defined as a failure or unwillingness, often strategic, to recognize that human rights law permits reasonable restrictions on all individual rights and that nationstates are granted a variable, but generally quite wide margin of discretion in determining their nature and scope in accordance with national and/or local particularities.

46. Moravcsik, supra note 2, at 197 (predicting no change absent some unexpected "epochal constitutional rupture-an Ackermanian "constitutional moment" (citing BRUCE A. ACKERMAN, WE THE PEOPLE: FOUNDATIONS (1991))). 
groups are doing and how their interests intersect or fail to intersect with promotion of international human rights law.

Special interest groups traditionally at the forefront of the fight against U.S. adherence to international human rights treaties over the last two decades appear in fact to have begun to reassess their strategies, finding ways that recurrence to such treaties may advance their domestic and international agendas. They have increasingly demanded greater U.S. participation in drafting the terms of international human rights agreements and even sought U.S. ratification of certain human rights treaties. ${ }^{47}$ This activity, taken together with the renewed mobilization of groups traditionally in favor of human rights treaty compliance - particularly through the coordination of the U.S. Human Rights Network ${ }^{48}$-is leading to a distinctly new situation for U.S. engagement with international human rights supervisory bodies and will lead to growing opportunities and challenges for all parties involved.

Increased civil society engagement (from both sides of the political spectrum) is being met, moreover, by growing institutionalization of human rights coordination within the U.S. government, particularly from the U.S. State Department, which is increasingly broadening its oversight from an exclusive focus on the human rights situation in other countries to domestic human rights achievement. In this regard, it is useful to recall that it was not until 1976-the year the ICCPR and ICESCR entered into force-that the U.S. government began to systematically monitor human rights achievement at all, in any country. ${ }^{49}$ In that year, Congress amended the Foreign Assistance Act to require the Secretary of State to transmit to it "a full and complete report" every year concerning "respect for internationally recognized human rights in each country proposed as a recipient of security assistance." $" 50$ The next year, the first forebear to the current position of Assistant Secretary of State for Democracy, Human Rights, and Labor was appointed, ${ }^{51}$ and an Interagency Group on Human Rights and Foreign Assistance was established. ${ }^{52}$ Yet, these focal points were mandated exclusively to report on

\section{See infra Section IV.B.}

48. Founded in 2003 , the U.S. Human Rights Network is a loosely coordinated community of over 250 human rights organizations and 1000 individuals committed to ensuring that U.S. human rights treaty commitments have effect for domestic communities. See The United States Human Rights Network, http://www.ushmetwork.org (last visited Apr. 20, 2009).

49. See supra note 5 .

50. This limited reporting requirement was authorized in the International Security Assistance and Arms Export Control Act, Pub. L. No. 94-329, 90 Stat. 729 (1976), which included an amendment to $\S 502 \mathrm{~B}$ of the Foreign Assistance Act of 1961, Pub. L. No. 87-195, 75 Stat. 424 (codified as amended in scattered sections of 22 U.S.C.). The requirement was expanded in the International Development and Food Assistance Act, Pub. L. No. 95-424, 92 Stat. 937 (1978), to include each member of the United Nations. The report was to be based on the internationally recognized human rights ideals detailed in the 1948 Universal Declaration of Human Rights, G.A. Res. 217A, U.N. GAOR, 3d Sess., 1st plen. mtg., U.N. Doc. A/810 (Dec. 12, 1948). In 1998, the mandate was extended to religious freedom. See International Religious Freedom Act, Pub. L. No. 105-292, § 102(b)(1), 112 Stat. 2787 (codified as amended at 22 U.S.C. $\$ 6401$ (2000 \& Supp. IV 2004)).

51. It was at the time called Coordinator (and then Assistant Secretary) of Human Rights and Humanitarian Affairs. The latter named bureau was renamed the Bureau for Democracy, Human Rights, and Labor under the Clinton administration.

52. See Hauke Hartmann, U.S. Human Rights Policy Under Carter and Reagan, 1977-1981, 23 HuM. RTS. Q. 402, 417 (2001). 
the human rights situation of other countries, particularly those receiving U.S. foreign assistance. ${ }^{53}$ They had no mandate to report on the human rights situation within the United States itself. It was not until two decades later-on the fiftieth anniversary of the Universal Declaration of Human Rights-that an interagency group was specifically mandated to coordinate executive agency response to domestic human rights concerns. ${ }^{54}$

Although that body, the Interagency Working Group on Human Rights Treaties (IAWG), functioned in that form for only two brief years, it represented a fundamental turning point in the orientation of U.S. human rights policy. Created by Executive Order 13,107, issued by President Clinton on December 10,1998, it was mandated to promote coordination among U.S. executive agencies in ensuring compliance with the human rights treaties the United States has ratified and supporting the work of international human rights mechanisms, including the United Nations, ILO, and OAS. ${ }^{55}$ The Order states that "[i]t shall be the policy and practice of the Government of the United States, being committed to the protection and promotion of human rights and fundamental freedoms, fully to respect and implement its obligations under the international human rights treaties to which it is a party, including the ICCPR, the CAT, and the CERD." ${ }^{56}$ Critically, it further instrucis all executive departments and agencies to "maintain a current awareness of United States international human rights obligations" relevant to their functions and to ensure that such functions are performed "so as to respect and implement those obligations fully." 57 This duty includes "responding to inquiries, requests for information, and complaints about violations of human rights obligations that fall within [each agency's] areas of responsibility." 58

The IAWG, for its part, was given a series of concrete coordination and oversight functions. These included coordinating the preparation of both treaty compliance reports to the United Nations, OAS, and other international organizations and responses to contentious complaints lodged therewith, as well as overseeing a review of all proposed legislation to ensure its conformity with international human rights obligations. The IAWG was also mandated to ensure that plans for public outreach and education on human rights provisions in treaty-based and domestic law were broadly undertaken and, significantly, to ensure that all nontrivial allegations of inconsistency with or breach of international human rights obligations be reviewed to determine whether any modifications to U.S. practice or laws are in order. ${ }^{59}$

The change of administrations in January 2001 meant that the work of the IAWG was never fully institutionalized. On February 13, 2001, it was

53. See Foreign Assistance Act, Pub. L. No. 87-195, 75 Stat. 424, 434 (1961) (codified as amended in scattered sections of 22 U.S.C.); see also Hartmann, supra note 52, at 417 (describing the limited economic focus of Human Rights Bureau's Interagency Group).

54. Exec. Order No. 13,107, 63 Fed. Reg. 68,991 (Dec. 10, 1998).

55. Id. $\S 1$.

56. Id. $\S 1$ (a) (emphasis added).

57. Id. $\S 2$.

58. Id. $\S \S 2-3$.

59. Id. $\S 4$. 
superseded-in form, if not function-by President George W. Bush's National Security Presidential Directive, which reorganized the National Security Council system. ${ }^{60}$ Specifically, the Bush Directive transferred the duties of the IAWG to a newly established Policy Coordination Committee (PCC) on Democracy, Human Rights, and International Operations, to be directed by the Assistant to the President for National Security Affairs. ${ }^{61}$ With the national security structure thrown into disarray by the $9 / 11$ attacks later that year, the PCC was not, however, formally constituted. It was not until 2003 that the staffs of the State Department and National Security Council, aware of a growing number of overdue periodic reports, began to work again on an ad hoc basis in preparing the relevant reports. ${ }^{62}$

Since then, U.S. responses to international human rights treaty bodies have been coordinated by the Office of the Legal Adviser of the U.S. State Department, with the assistance, when necessary, of legal consultants with expertise in the area and other executive agencies and departments, particularly the National Security Council and the Departments of Justice, Homeland Security, the Interior, Defense, Health and Human Services, and Labor. ${ }^{63}$ This is true both for the preparation of U.S. periodic reports on domestic compliance with human rights treaties and of U.S. responses to individual complaints and precautionary measures. ${ }^{64}$ Although this work is done on an ad hoc basis, without dedicated staff and resources, the framework for a more structured response is at least technically in place. This framework requires formal reconstitution and the infusion of resources and staff that ideally, at least with respect to periodic reporting functions, are functionally independent of the Office of the Legal Adviser-more like the current structure for preparing the State Department's country reports on the human rights situation in other nations. ${ }^{65}$ It is important to note that while this latter mandate remains limited to non-U.S. jurisdictions, the introduction to the 2006 report recognized for the first time that the U.S. government, too, has fallen short of international standards in some areas. ${ }^{66}$

60. Memorandum from George W. Bush, President of the U.S., National Security Presidential Directive (Feb. 13, 2001), available at http://www.fas.org/irp/offdocs/nspd/nspd-1.htm (abolishing system of Interagency Working Groups established under Clinton administration).

61. See id.

62. Interview with Mark P. Lagon, Deputy Assistant Sec'y of State, Bureau of Int'l Affairs, U.S. Dep't of State, and Robert K. Harris, Assistant Legal Adviser, U.S. Dep't of State (Feb. 1, 2007) [hereinafter Lagon-Harris Interview].

63. Id.

64. For their part, responses to ILO complaints and periodic reports are prepared principally by the U.S. Department of Labor.

65. The State Department has a sizable staff of attorneys working exclusively on preparing Annual Country Human Rights Reports. This staff is assisted by diplomats in U.S. embassies and consulates around the world. Interview with Steven R. Hill, Att'y-Adviser, U.S. Dep't of State, in Washington, D.C. (Feb. 8, 2007) [hereinafter Hill interview]. A similar mechanism could be set up through which a permanent staff of attorneys within the State Department or other federal agency or entity, preferably with an autonomous monitoring mandate, is assisted by the staffs of federal offices in the fifty states, together with the voluntary inputs of state officials.

66. U.S. Dep't of State, 2006 Country Reports on Human Rights Practices, http://www.state.gov/g/drl/rls/hrrpt/2006 (last visited Apr. 20, 2009); see also Brian Knowlton, Report on Rights Abuses Singles Out Darfur Genocide, INT'L HeRALD TRIB., Mar. 7, 2007, at 4. 
This movement within the executive branch ${ }^{67}$ is being matched by movements within the legislative and judicial branches. The judicial branch is increasingly, if slowly and cautiously-and in the face of certain powerful resistance ${ }^{68}$-referring to comparative human rights jurisprudence in resolving domestic disputes and interpreting domestic statutory and constitutional law. ${ }^{69}$ The Senate Judiciary Committee, moreover, created a new Subcommittee on Human Rights and the Law in 2007, reauthorizing it in 2009. Such Senate bodies, together with the bipartisan Congressional Human Rights Caucus, could play a critical role in coordinating with a new National Human Rights Commission, National Human Rights Office, and reconstituted IAWG or PCC, particularly if the latter entities were given a specific legislative reporting mandate on human rights concerns arising within government departments and agencies. ${ }^{70}$ At a minimum, the playing field for domestic advocates in pushing their respective policy agendas has been materially altered in recent years, changing the opportunity structure for using human rights language to achieve distinct policy ends. Opponents and proponents have taken note, adjusting their strategies accordingly. ${ }^{71}$

67. Although President Obama has taken no action yet on a proposed Executive Order to revitalize and strengthen the Clinton-era IAWG, he has issued an Executive Order establishing a more limited-mandate White House Council on Women and Girls that would function under a similar interagency structure. See Executive Order No. 13,506, 74 Fed. Reg. 11,271 (Mar. 16, 2009).

68. Justice Antonin Scalia has been the most vocal judicial opponent of referring to foreign law in domestic jurispnudence. See, e.g., Atkins v. Virginia, 536 U.S. 304, 347-48 (2002) (Scalia, J., dissenting). A minority of representatives within the U.S. House of Representatives has likewise resisted this trend, introducing two House resolutions in 2004 and 2005, respectively, that sought to legislatively preclude domestic courts from referring to "judgments, laws, or pronouncements of foreign institutions" in determining the meaning of U.S. laws. See H.R. Res. 97, 109th Cong. (2005); H.R. Res. 568, 108th Cong. (2004). Though voted out of committee, the two proposals, which garnered seventy-four and eighty-four House cosponsors respectively, were never brought to a vote in the full House. A similar bill was introduced to the U.S. Senate in 2005 , but did not make it out of committee. See S. Res. 92, 109th Cong. (2005). Importantly, Supreme Court Justices, including Justice Scalia, have indicated constitutional objections to such legislative initiatives on separation-of-powers grounds. See Tony Mauro, Scalia Tells Congress To Stay Out of High Court Business, LEGAL TImES, May 19, 2006, available at http://www.law.com/jsp/article.jsp?id=1147943135671.

69. For recent Supreme Court examples, see, for instance, Roper v. Simmons, 543 U.S. 551 (2005); Lawrence v. Texas, 539 U.S. 558 (2003); Grutter v. Bollinger, 539 U.S. 306 (2003); and Atkins v. Virginia, 536 U.S. 304 (2002). The Court has, of course, long referred to international law in general, either as federal common law or in interpreting domestic statutes so as to avoid conflict with international treaty commitments. See, e.g., Banco Nacional de Cuba v. Sabbatino, 376 U.S. 398 (1964); The Paquete Habana, 175 U.S. 677 (1900); Murray v. Charming Betsy, 6 U.S. (2 Cranch) 64 (1804). For reviews and discussion of this jurisprudence, both as a contemporary and historical matter, see, for example, Steven G. Calabresi \& Stephanie Dotson Zimdahl, The Supreme Court and Foreign Sources of Law: Two Hundred Years of Practice and the Juvenile Death Penalty Decision, 47 WM. \& MARY L. REv. 743 (2005); Sarah H. Cleveland, Our International Constitution, 3I YALE J. INT'L L. 1 (2006); and Vicki C. Jackson, Constitutional Comparisons: Convergence, Resistance, Engagement, 119 HARV. L. REv. 109 (2005).

70. Such a reporting mandate might be similar to the one given to the State Department under the Foreign Assistance Act. The benefit of a legislative mandate is that it cannot be abolished through executive order with periodic changes in the White House.

71. See infra Section IV.B. 


\section{SUPERVISORY TREATY BODY SYSTEM AND THE SCOPE OF U.S. ENGAGEMENT}

Although scarcely covered by U.S. media sources and hence not well known outside narrow advocacy circles, ${ }^{72}$ the United States has remained actively engaged in the work of supranational human rights treaty bodies, consistent with its international treaty commitments. "Human rights treaty bodies" refer to the committees or commissions of independent experts ${ }^{73}$ set up under key human rights treaties to supervise, through quasi-adjudicatory and promotional powers, state-party compliance with treaty undertakings. There are currently eight U.N. human rights treaty bodies operating under the auspices of the U.N. Office of the High Commissioner on Human Rights, four of which exercise direct supervisory jurisdiction over the United States. ${ }^{74}$ These include the Human Rights Committee, the Committee Against Torture, the Committee on the Elimination of Racial Discrimination, and the Committee on the Rights of the Child. ${ }^{75}$ The United States is also subject to the supervisory jurisdiction of the Inter-American Commission on Human Rights, one of the two principal human rights organs of the OAS, ${ }^{76}$ as well as the ILO Committee of Experts and Committee on Freedom of Association. ${ }^{77}$

While not courts in the sense of having competence to issue legally binding rulings on the matters and parties before them, these treaty bodies often exercise quasi-adjudicatory functions that approximate that role. ${ }^{78}$ Most

72. For a discussion of the phenomenological biases of the media as a participant in the international legal process, see Monica Hakimi, The Media as Participant in the International Legal Process, 16 DUKE J. COMP. \& INT'L L. 1, 24 (2006).

73. Such experts are nominated and elected by the states parties to the treaty but serve in their personal capacities, generally for renewable four-year terms. Most treaties require them to be persons of high moral authority and recognized competence in the field of international human rights law; in practice, they are of various skill sets and backgrounds.

74. The United States is not presently subject to the jurisdiction of the other four: the Committee on Economic, Social, and Cultural Rights, the Committee on the Elimination of All Forms of Discrimination against Women, the Committee on Migrant Workers and Members of their Families, and the Committee on the Rights of Persons with Disabilities. See supra note 28 and accompanying text.

75. While the United States has not yet ratified the Convention on the Rights of the Child, it has ratified the two optional protocols thereto, each of which entails a periodic reporting obligation to the Committee on the Rights of the Child.

76. See infra note 108 and accompanying text. The other is the Inter-American Court of Human Rights, the contentious jurisdiction of which the United States has not recognized. For more on the Court, see Tara J. Melish, Inter-American Court of Human Rights: Beyond Progressivity, in Social RIGHTS JURISPRUDENCE: EMERGING TRENDS IN COMPARATIVE AND INTERNATIONAL LAW 372 (Malcolm Langford ed., 2008).

77. The former has mandatory supervisory jurisdiction over the ILO's core labor standards, two of which the United States has ratified: No. 105 on the Abolition of Forced Labor and No. 182 on the Elimination of the Worst Forms of Child Labor. See U.S. Dep't of Labor, Bureau of Int'I Labor Affairs, International Labor Organization, http://www.dol.gov/ilab/programs/oir/ILO.htm (last visited Apr. 2, 2009) (recognizing the requirement that the United States regularly submit reports to ILO supervisory bodies). The latter exercises contentious jurisdiction over collective complaints involving freedom of association regardless of whether the member state has ratified ILO treaties; as of 2008, it has considered forty-nine complaints against the United States. See Steve Charnovitz, The ILO Convention on Freedom of Association and lts Future in the United States, 102 AM. J. INT'L L. 90, 92 (2008).

78. See U.N. Human Rights Comm., General Comment 33, The Obligations of States Parties Under the Optional Protocol to the International Covenant on Civil and Political Rights, para. 11, U.N. Doc. CCPR/C/GC/33 (Nov. 5, 2008) ("While the function of the Human Rights Committee in 
are empowered to receive petitions of alleged human rights violations from either individual or collective complainants, ${ }^{79}$ review evidentiary or informational submissions, find facts, interpret legal rules, and issue nonbinding decisions or recommendations. Such recommendations are increasingly accompanied by follow-up and compliance reporting requirements, designed to ensure that appropriate measures are taken by states to give domestic legal effect to treaty body pronouncements. These quasijudicial jurisdictional functions are supplemented by functions of a more overtly promotional nature, such as periodic reporting procedures and their accompanying committee conclusions and recommendations, the issuance of general comments or observations, onsite visits, thematic hearings, advisory services, and general reports on distinct human rights matters or issues.

U.S. engagement with these bodies extends across the full range of treaty body activities, including each of the three principal types of supervisory mechanisms: periodic reporting processes; individual and collective complaints procedures; and special mandate or promotional mechanisms. Because the scope of engagement with each of these mechanisms speaks so powerfully to the parameters of U.S. human rights policy, each merits slightly closer attention here.

\section{A. Periodic Reporting Process}

The quintessential function of human rights treaty bodies is a periodic reporting process. ${ }^{80}$ Periodic reporting reflects the subsidiary nature of human rights law vis-à-vis domestic law and is designed to assist states in their central obligation under human rights treaty law: to ensure that protected rights have domestic legal effect through the adoption of "appropriate" or "necessary" measures, determined in context. ${ }^{81}$ States parties are thus required to submit reports about the measures they have adopted to give effect to the rights recognized in the treaty and about progress and setbacks in the enjoyment of those rights.

considering individual communications is not, as such, that of a judicial body, the views issued by the Committee under the Optional Protocol exhibit some important characteristics of a judicial decision. They are arrived at in a judicial spirit, including the impartiality and independence of Committee members, the considered interpretation of the language of the Covenant, and the determinative character of the decisions.").

79. The U.N. and OAS mechanisms have individual standing rules, while the ILO has jurisdiction over collective complaints lodged by, and on behalf of, workers' or employers' organizations.

80. An exception is the Inter-American Commission on Human Rights, which, despite an explicit competence to supervise a periodic reporting process, see American Convention on Human Rights art. 42, Nov. 22, 1969, 1144 U.N.T.S. 123 (1969) [hereinafter American Convention], has declined to formally pursue it over the years. A periodic reporting function has been set up under the Additional Protocol to the American Convention in the Area of Economic, Social, and Cultural Rights and guidelines are currently being drawn up by the Inter-American Commission for the preparation of reports by states parties. See, e.g., Org. of American States, Gen. Assembly Res. 2074, AG/RES. 2074 (XXXV-O/05) (June 7, 2005).

81. See, e.g., Comm. on Econ., Soc., and Cultural Rights [CESCR], Reporting by States Parties, General Comment No. 1, Annex III, at 87, U.N. Doc. E/1989/22 (1989) (defining objectives of periodic reporting). 
Each of the core U.N. human rights treaties envisions a mandatory periodic reporting process under the supervision of the relevant treaty body. An initial report must generally be provided within one year of ratification or accession, followed by a periodic report every two to five years or as the committee so requests. ${ }^{82}$ By becoming party, the United States has undertaken periodic reporting requirements under the CERD, the CAT, the ICCPR, and the two optional protocols to the CRC. Although the United States-not unlike many other nations-has frequently been late in submitting its reports, ${ }^{83}$ it has actively engaged with the supervisory treaty bodies in the periodic reporting process, particularly as nongovernmental organizations (NGOs) have become increasingly savvy in using international procedures and pressure points to ensure timely, substantive, and participatory reporting.

In this regard, the United States submitted its first report under the ICCPR to the Human Rights Committee in $1994,{ }^{84}$ defending it in 1995. This was followed by its first CAT report in 1999 and its first CERD report in $2000 .^{85}$ These reports were defended before the U.N. Committee on Torture and the U.N. Committee on the Elimination of Racial Discrimination, respectively, in 2000 and 2001. In 2005, the United States submitted its second CAT report and its combined second and third ICCPR reports, ${ }^{86}$ defending each in Geneva in 2005 and 2006 , respectively. ${ }^{87}$ It presented its combined fourth, fifth, and sixth report to the CERD Committee in 2007, which it defended in $2008 .{ }^{88}$ It has regularly submitted reports as well-on a two-year periodic basis - to the ILO Committee of Experts. ${ }^{89}$

82. See, e.g., ICCPR, supra note 23 , art. 40(1); CAT, supra note 24, art. 19; CERD, supra note 25 , art. 9.

83. This delay stems from several mostly institutional factors. First, until early 1999, the United States lacked any dedicated body with explicit competence to prepare and supervise such reports, causing many deadlines to be missed. While a coordinating mechanism exists today, it continues to lack dedicated staff and resources, thus constraining its capacity to produce reports on time, especially given the significant institutional coordination and commitment needed for their production. It is for this reason that the institutional mechanisms proposed in Part VII are so crucial.

84. Human Rights Comm., Consideration of Reports Submitted by States Parties Under Article 40 of the Covenant: Initial Reports of States Parties Due in 1993, Addendum: United States of America, U.N. Doc. CCPR/C/81/Add.4 (Aug. 24, 1994).

85. U.N. Comm. Against Torture, Consideration of Reports Submitted by States Parties Under Article 19 of the Convention: Initial Reports of States Parties Due in 1995, Addendum: United States of America, U.N. Doc. CAT/C/28/Add.5 (Oct. 15, 1999). The United States missed its CERD report due dates in 1995, 1997 and 1999, and thus submitted its combined first, second, and third reports as a single document in 2000. Comm. on the Elimination of Racial Discrimination, Reports Submitted by States Parties Under Article 9 of the Convention: Third Periodic Reports of States Parties Due in 1999, Addendum: United States of America, U.N. Doc. CERD/C/351/Add. 1 (Sept. 21, 2000).

86. These were submitted one and seven years late, respectively. See U.N. Comm. Against Torture, Consideration of Reports Submitted by States Parties Under Article 19 of the Convention: Second Periodic Reports of States Parties Due in 1999, Addendum: United States of America, U.N. Doc. CAT/C/48/Add.3 (May 6, 2005); Human Rights Comm., Consideration of Reports Submitted by States Parties Under Article 40 of the Covenant: Third Periodic Reports of States Parties Due in 2003, Addendum: United States of America, U.N. Doc. CCPR/C/USA/3 (Nov. 28, 2005) [hereinafter Third Periodic Report].

87. For an account of the U.S. defense in 2006, see Colette Connor, Recent Development, The United States' Second and Third Periodic Report to the United Nations Human Rights Committee, 49 HARV. INT'L L.J. 509 (2008).

88. See U.S. CERD Report 2007, supra note 37.

89. See U.S. Dep't of Labor, supra note 77. 
The supervisory procedures associated with periodic reporting tend formally to be characterized as a process of "constructive dialogue" between treaty bodies and states parties. ${ }^{90}$ After a state party submits its written report, the treaty body prepares a list of priority issues that the state party should be prepared to discuss at a scheduled hearing in Geneva. ${ }^{91}$ On the basis of the state party's written report, its oral presentations, and any additional information made available to the committee, the supervising committee prepares a public report in which it identifies areas of progress and areas of concern with respect to the state's human rights achievement. It then draws conclusions and sets forth recommendations for how the state party might take further measures in areas where deficiencies or weaknesses were identified. Though technically a friendly process, treaty-based reporting has become increasingly adversarial over the years as treaty bodies have gained prominence and international authority. ${ }^{92}$ As a result, their recommendations are often interpreted by domestic and international advocacy groups as a binding "legal decision" requiring immediate domestic execution by national authorities. ${ }^{93}$ This view is often reinforced by committee requests that the state party submit additional information if committee questions were not answered fully in oral proceedings, a request sometimes construed by advocates as a requirement to report on follow-up measures.

U.S. participation in this process is marked by five major characteristics, each determinative in appreciating the mediated nature of U.S. engagement policy. First, the United States prepares extensive and detailed reports to the committee. In contrast to many states, which often submit incomplete or insufficiently inclusive reports, ${ }^{94}$ the United States closely hews to the committee-issued guidelines in preparing its consistently lengthy and comprehensive submissions. ${ }^{95}$

90. See, e.g., Philip Alston, U.S. Ratification of the Covenant on Economic, Social and Cultural Rights: The Need for an Entirely New Strategy, 84 AM. J. INT'L L. 365, 370 (1990) (noting that periodic reporting function is "based on the assumption that a constructive dialogue between the Committee and the state party, in a non-adversarial, cooperative spirit, is the most productive means of prompting the government concerned to take the requisite action").

91. These questions are often based on the information provided to treaty bodies in civilsociety-prepared "shadow reports," prepared to highlight and correct misstatements or generalizations in official state reports, fill in overlooked areas with accurate facts, details, and statistics, and generally present an alternative view for the expert U.N. committee to consider in assessing state progress and setbacks and in making recommendations for domestic improvements.

92. This growing prominence and global authority has in many ways emboldened treaty bodies to be more confrontational with U.S. delegations. See Murphy, supra note 12, at 57 ("For the [ICJ], the lesson [of increasing global authority unbeholden to major powers] may be not to tread lightly with respect to the United States but, rather, to tread heavily unless doing so would be viewed generally as bias.").

93. See infra note 260 and accompanying text.

94. The U.N. Human Rights Committee, for example, regularly laments the lack of comprehensiveness in state party reports. See, e.g., U.N. Human Rights Comm., General Comment 2: Reporting Guidelines (Thirteenth Session, 1981), at 3, I 1, U.N. Doc. HRIGENIIRev.1 (July 29, 1994) [hereinafter General Comment 2]. The Committee has correspondingly issued guidelines to assist states in preparing reports under the respective treaties. U.N. Human Rights Comm., Consolidated Guidelines for State Reports Under the International Covenant on Civil and Political Rights, U.N. Doc. CCPR/C/66/GUL/Rev.2 (Feb. 2, 2001).

95. The United States's third periodic report to the Human Rights Committee, for example, was 120 single-spaced pages, covering U.S. achievements with respect to each of the twenty-seven 
Second, the United States participates in Geneva-based meetings-and increasingly in contentious OAS proceedings-with large, high-level interagency delegations. Indeed, the United States sends not only a high-level official spokesperson to present and defend its reports, but also a full delegation of high-level officials from each of the major executive agencies and departments to present and answer committee questions in their respective areas of competence. ${ }^{96}$ This level of engagement reflects the high standards requested of governments by the Geneva-based committees to ensure the effectiveness of the process. ${ }^{97}$

Third, the United States consistently affirms, particularly in its oral presentations to treaty bodies, that it recognizes it is not perfect and has definite gaps to fill. ${ }^{98}$ The central message of the treaty-mandated reports is thus that the United States "is trying in good faith to bring its domestic practices into compliance with international standards." ${ }^{.99}$ Within this context, it formally welcomes the views of the treaty body as part of a constructive dialogue aimed at assisting it in identifying areas of weakness in its own

substantive rights guaranteed in the ICCPR. See Third Periodic Report, supra note 86. The United States's 2007 CERD Report is over 170 pages, and includes coverage with respect to each provision of the CERD, as well as separate annexes on examples of state-level civil rights programs, the U.S. legal position on the Western Shoshone case, and new domestic laws adopted since 2000, when the United States submitted its first CERD report. See U.S. CERD Report 2007, supra note 37.

96. At its most recent appearances before the U.N. Human Rights Committee and Committee Against Torture, for example, the U.S. delegation was comprised of over thirty government officials from at least six executive agencies or departments.

97. See, e.g., General Comment 2, supra note 94, I 4 ("The Committee wishes to state that, if it is to be able to perform its functions under article 40 as effectively as possible and if the reporting State is to obtain the maximum benefit from the dialogue, it is desirable that the States representatives should have such status and experience (and preferably be in such number) as to respond to questions put, and the comments made, in the Committee over the whole range of matters covered by the Covenant.").

While the U.N. treaty bodies tended to acknowledge this effort in its initial reports, they have declined to do so in later reports, as the relationship with the United States has grown more contentious on matters relating to the Iraq war and counterterrorism measures. Compare U.N. Human Rights Comm., Concluding Observations of the Human Rights Committee: United States of America, शा 26768, U.N. Doc. CCPR/C/79/Add.50 (Oct. 3, 1995) (expressing appreciation of the high quality of report, "participation of high-level delegation which included a substantial number of experts in various fields relating to the protection of human rights in the country," and well-structured replies), with U.N. Human Rights Comm., Concluding Observations of the Human Rights Committee: United States of America, U.N. Doc. CCPR/C/USA/CO/3/Rev.1 (Dec. 18, 2006) (not mentioning high-level delegation or quality of process)

98. See, e.g., Robert Harris, Assistant Legal Adviser, U.S. Dep't of State, Remarks to the U.N. Human Rights Comm. in Geneva, Switzerland (July 17, 2006) (noting that the United States recognizes that it has gaps to fill in its human rights record under ICCPR); Harold Hongju Koh, U.S. Assistant Sec'y of State for Democracy, Human Rights, and Labor, Remarks to the U.N. Committee Against Torture in Geneva, Switzerland (May 10, 2000), available at http://www.state.gov/documents/ organization/6589.doc ("Although we are very proud of our record in eliminating torture, we acknowledge continuing areas of concern within the United States. Although our commitment is unambiguous, our record is not perfect."); see also Condoleezza Rice, U.S. Sec'y of State, Briefing on the State Department's 2006 Country Reports on Human Rights Practices in Washington, D.C. (Mar. 6, 2007) ("We do not issue these reports because we think ourselves perfect, but rather because we know ourselves to be deeply imperfect, like all human beings and the endeavors that they make. Our democratic system of governance is accountable, but it is not infallible.").

99. See, e.g., Harold Hongju Koh, A United States Human Rights Policy for the 21st Century, 46 ST. LOUIS U. L.J. 293, 308 (2002). 
internal process, affirming that committee suggestions are duly and appropriately taken into consideration. ${ }^{100}$

Fourth, and relatedly, members of official delegations and those who prepare reports tend to recognize the genuine utility of the reporting process for gaining a better understanding of the precise ways in which the United States is and is not in compliance with international standards, even as the process is affirmed to be nonbinding and exclusively promotional. ${ }^{101}$ In this sense, the engagement process itself is considered useful and beneficial to internal processes of self-reflection and broad political debate, even as it carries no independent binding force.

Finally, while the United States manifests a high degree of openness and willingness to answer treaty body questions in virtually all areas of domestic human rights policy, there are certain policy issues that it declines to address other than "as a matter of courtesy." 102 These predominate in two areas: one, the territorial scope of treaty body competence and, two, the intersection of human rights and humanitarian law. ${ }^{103}$ The United States insists that U.N. and OAS treaty bodies lack jurisdiction to consider U.S. human rights policy as it affects persons outside its territorial boundaries and as it intersects with the law of armed conflict, which, it asserts, prevails as lex specialis at points of intersection and hence falls outside treaty body jurisdiction. ${ }^{104}$

100. See, e.g., Harris, supra note 98 (noting that the United States welcomes the Committee's views, and that such views are appropriately taken into consideration by agencies of the U.S. government). According to U.S. representatives, what grates U.S. officials is not the process itselfwhich, they affirm, is genuinely appreciated, particularly for the opportunity to orally defend U.S. policy positions on human rights internationally - but when Committee members appear unopen to dialogue on debatable issues and insensitive to areas of simple disagreement, particularly as they relate to U.S. jurisdictional concerns on the substantive limits of treaty body competence. Lagon-Harris Interview, supra note 62

101. This appreciation, often acknowledged to be unexpected, has been consistently expressed in multiple fora by government officials responsible for preparing treaty reports-equally in public meetings between U.S. departments and agencies, treaty bodies, and domestic advocacy groups and in private interviews or conversations in which this author has taken part. See, e.g., Hill Interview, supra note 65; Lagon-Harris Interview, supra note 62.

102. See, e.g., U.N. Human Rights Comm., Comments by the Government of the United States of America on the Concluding Observations of the Human Rights Committee, U.N. Doc. CCPR/C/USA/CO/3/REV.1/ADD.1 (Feb. 12, 2008).

103. Mark P. Lagon, Deputy Assistant Sec'y of State for Int'l Org. Affairs, Statement at Media Roundtable with Senior Government Officials (July 17, 2006), available at http://geneva.usmission.gov/ Press2006/0717PressBriefing.html ("There are some issues that will come up in this defense that have to do with the war on terrorism and the United States conduct of it. It is our firm belief that those issues in large part lie beyond the scope of the treaty, those things that have to do with conduct outside of the territory of the United States or those that belong to the questions of law of war rather than human rights law. Nonetheless, the United States will answer those controversial questions as a courtesy to the committee, and importantly, as a matter of openness in the international community.").

104. On the former point, see Third Periodic Report, supra note 86, Annex 1, at 109-11. This posture predates but supports the U.S. "war on terror" policy of holding suspected terrorists and "enemy combatants" outside of U.S. territory, such as in Guantanamo Bay, Cuba or on offshore vessels. Significantly, the extraterritoriality point is pressed as a matter of human rights treaty law, even while accepting the Supreme Court's decision in Rasul v. Bush, 542 U.S. 466 (2004), that the U.S. judiciary may exercise jurisdiction over extraterritorial abuses taking place in loci over which the United States exercises effective ("exclusive") authority and control. This constitutional exception to the extraterritoriality principle is effectively identical to that recognized in international human rights law generally. See, e.g., Coard v. United States, Case 10.951, Inter-Am. C.H.R., Report No. 109/99, OEA/Ser.L/V/II.106, doc. 6 rev., 37 (1999) ("In principle, the inquiry turns not on the presumed victim's nationality or presence within a particular geographic area, but on whether, under the specific 


\section{B. Individual and Collective Complaint Procedures and Precautionary Measures}

Just as the United States actively engages in periodic reporting processes under all relevant treaty regimes, it likewise engages in individual and collective communication procedures. The United States has not, however, optionally acceded to any such procedure. Thus, it has not recognized the right of individuals to initiate individual communications or claims procedures under the ICCPR, CAT, or CERD, nor has it recognized the contentious competence of the Inter-American Court of Human Rights, the properly judicial (as opposed to quasi-judicial) organ of the regional human rights system. ${ }^{105}$ These adjudicatory and quasi-adjudicatory procedures provide legal standing for individuals within a state party's jurisdiction to bring contentious claims alleging that the state is responsible, through its conduct, for violating the individual's treaty-protected rights.

There are, however, two mandatory mechanisms in international human rights law that allow individuals to bring human rights complaints against the United States, as well as one mechanism for collective complaints. The first is the case-based contentious jurisdiction of the Inter-American Commission on Human Rights (the Commission). The second is the precautionary measure or early warning/urgent action procedure recognized respectively by the Commission and the U.N. human rights treaty bodies. ${ }^{106}$ Finally, the United States is subject to a collective complaints procedure regarding compliance with ILO labor rights treaties, through which labor and employer organizations may bring complaints against the United States before the ILO Committee on Freedom of Association. ${ }^{107}$ The United States recognizes and engages with each of these three sets of procedures, appearing and presenting arguments at all procedural stages of litigation.

With regard to individual complaints procedures, the most significant and extensively used of the two applicable to the United States is the quasiadjudicatory petitions process of the Inter-American Commission. Formally established in 1959, the Commission is mandated under the OAS Charter to "promote the observance and protection of human rights and to serve as a

circumstances, the State observed the rights of a person subject to its authority and control." (emphasis added)).

105. Each of these nonmandatory procedures requires the deposit of an independent instrument of jurisdictional recognition for operativity. See, e.g., American Convention, supra note 80, art. 62.

106. The formal competence of treaty bodies to issue these measures is generally established in their respective rules of procedure. See, e.g., Rules of Procedure of the Inter-American Commission on Human Rights art. 25, OEA/Ser.L/V/II.111, at 171 (2001) [hereinafter Commission Rules] ("In serious and urgent cases, and whenever necessary according to the information available, the Commission may, on its own initiative or at the request of a party, request that the State concerned adopt precautionary measures to prevent irreparable harm to persons."). For information on the CERD's urgent action or early-warning procedure, see Office of the U.N. High Commissioner for Human Rights, Committee on the Elimination of Racial Discrimination: Monitoring Racial Equality and Non-Discrimination, http://www2.ohchr.org/english/bodies/cerd (last visited Apr. 4, 2009).

107. These will not be substantively addressed here. For an assessment, see Charnovitz, supra note 77. The full range of cases and complaints against the United States can be accessed at International Labour Organization, International Labour Standards, http://www.ilo.org/ilolex/english/caseframeE.htm (follow "United States" hyperlink) (last visited Apr. 4, 2009). 
consultative organ of the [OAS] in these matters." ${ }^{108}$ In this regard, the Commission has both quasi-adjudicative and promotional functions.

Persons within the jurisdictional boundaries of the United States at the time of an alleged violation can therefore bring human rights complaints through this supranational mechanism for violation, to their detriment, of any of the rights recognized in the American Declaration on the Rights and Duties of Man, including the rights to health, education, property, life, due process, judicial protection, and nondiscrimination. ${ }^{109}$ To date, the majority of cases lodged against the United States have involved persons on death row claiming due process denials with respect to the rights to life and judicial protection, including through failure to provide consular notification to nonnationals. ${ }^{110}$ Nevertheless, the Commission has considered a growing number of U.S. cases beyond the death penalty context, increasingly so in recent years. These have involved the rights of indigenous persons to ancestral territory, ${ }^{111}$ voting rights in the nation's capital, ${ }^{112}$ summary deportations, ${ }^{113}$ abortion, ${ }^{114}$ abuses committed during U.S. military action abroad where effective authority or control was maintained over the alleged victims, ${ }^{115}$ capital punishment of

108. Charter of the Organization of American States art. 106, Apr. 30, 1948, 2 U.S.T. 2394, 119 U.N.T.S. 3 (entered into force Dec. 13, 1951); see also id. arts. 3, 16, 51, 112, 150. The Commission has affirmed that, consistent with its Statute and Rules of Procedure, it has jurisdiction to consider individual petitions lodged against the United States, as with all thirty-five OAS member states, by virtue of the United States's 1951 ratification of the OAS Charter. See, e.g., Sánchez v. United States, Petition 65/99, Inter-Am. C.H.R., Report No. 104/05, OEA/Ser.L/V/II.124, doc. 5, I 50 (2006) ("United States of America deposited its instrument of ratification of the OAS Charter on June 19, 1951 and has been subject to the Commission's jurisdiction since 1959, the year in which the Commission was created."); see also Roach v. United States, Case 9647, Report No. 3/87, OEA/Ser. L./V/II.71. doc. 9 rev. 1 (1987).

109. American Declaration of the Rights and Duties of Man, OAS Res. XXX, International Conference of American States, 9th Conf., OAS Doc. OEA/Ser. L./V/II.23, doc. 21 rev. 6 (1948). Article 1 of the Commission's Statute defines the human rights the Commission is competent to apply as "[t]he rights set forth in the American Convention on Human Rights, in relation to the States Parties thereto" and "[t]he rights set forth in the American Declaration of the Rights and Duties of man, in relation to the other member states." Statute of the Inter-American Commission on Human Rights, O.A.S. Res. 447 (IX-0/79) (1979).

110. See, e.g., Workman v. United States, Case 12.261, Inter-Am. C.H.R., Report No. 33/06, OEA/Ser.L/V/II.127, doc. 4 rev. 1 (2007); Medina v. United States, Case 12.421, Inter-Am. C.H.R., Report No. 91/05, OEA/Ser.L/V/II.124, doc. 5 (2005). A great number of these cases have dealt with failures to provide consular notification under the Vienna Convention on Consular Relations.

111. Dann v. United States, Case 11.140, Inter-Am. C.H.R., Report No. 75/02, OEA/Ser. L./V/II.117. doc. 7 rev. 1 (2002); Cherokee Nation v. United States, Case 11.071, Inter-Am. C.H.R., Report No. 6/97, OEA/Ser.L/V/II.a5, doc. 7 (1997).

112. Statehood Solidarity Committee v. United States, Case 11.204, Inter-Am. C.H.R., Report No. 98/03, OEA/Ser. L/V/II.114, doc. 70 rev. 2 (2003).

113. See, e.g., Smith v. United States, Petition 8-03, Inter-Am. C.H.R., Report No. 56/06, OEA/Ser.L/VII.127, doc. 4 rev. 1 (2007); Armendariz v. United States, Petition 526-03, Inter-Am. C.H.R., Report No. 57/06, OEA/Ser.L/V/II.127, doc. 4 rev. 1 (2007).

114. "Baby Boy" v. United States, Case 2141, Inter-Am. C.H.R., Res. No. 23/81, OEA/Ser.L/V/II.54, doc. 9 rev. 4 (1981).

115. Coard v. United States, Case 10.951, Inter-Am. C.H.R., Report No. 109/99, OEA/Ser.L/V/II.106, doc. 6 rev., I 37 (1999) (U.S. attacks on Grenada); Hill v. United States, Case 9213, Inter-Am. C.H.R., Report No. 3/96, OEA/Ser.L/V/II.9I, doc. 7, at 201 (1996) (closing case after full reparation provided to alleged victims of U.S. attack on civilian hospital in Grenada); Salas v. United States, Case 10.573, Inter-Am. C.H.R., Report No. 31/93, OEA/Ser.L/V/I.85, doc. 9 rev. (1993) (U.S. invasion of Panama); Disabled Peoples' Int'l v. United States, Case 9213, Inter-Am. C.H.R. 198, OEA/Ser.L/V/II.71, doc. 9 rev. 1 (1987) (U.S. attacks on Grenada). 
minors, ${ }^{116}$ and the rights of interdicted refugees and detainees held in INS detention facilities and at Guantánamo Bay. ${ }^{17}$ They have likewise involved freedom from extraordinary rendition, the right not to be deported where HIV treatment is not available in the return country, ${ }^{118}$ border controls, ${ }^{119}$ the right to reparation for civil rights abuses, ${ }^{120}$ welfare reform, ${ }^{121}$ and the right to police enforcement of domestic violence restraining orders, ${ }^{122}$ among a growing variety of others.

While the Commission frequently finds the U.S. internationally responsible for rights violations, the majority of cases lodged against the United States are ruled inadmissible, either in pre-admissibility vetting procedures ${ }^{123}$ or, following admissibility hearings, in published admissibility reports. This is due principally to jurisdictional defects in petitioners' arguments, including failure to properly exhaust domestic remedies, lack of victim standing, failure to state a prima facie claim, or lack of ratione temporis, ratione personae, or ratione loci jurisdiction. ${ }^{124}$

Within this context, the United States participates reliably in individual petitions processes before the Commission, as it has since at least 1977, the year President Carter signed the American Convention on Human Rights. ${ }^{125}$ As the cases have become more varied and complex over the last decade, U.S. participation in hearings has likewise become more active, extensive, and substantive, with strong positive effects for the system as a whole. While the United States has frequently argued that the Declaration, as a non-treaty, creates no binding obligations upon the U.S. government, its submissions

116. See, e.g., Patterson v. United States, Case 12.439, Inter-Am. C.H.R., Report No. 25/05, OEA/Ser.L/V/II.124, doc. 5 (2005) (17 years old when committed crime); Thomas v. United States, Case 12.240, Inter-Am. C.H.R., Report No. 100/03, OEA/Ser.L/V/II.118 (2003) (17 years old when committed crime); Roach v. United States, Case 9467, Inter-Am. C.H.R., Report No. 3/87, OEA/Ser.L/V/II.71, doc. 9 rev. 1, \$17 46-49 (1987) (17 years old when committed crime).

117. Ferrer-Mazorra v. United States, Case 9903, Inter-Am. C.H.R., Report No. 51/01, OEA/L/V/II.111, doc. 20 rev., at 1188 (2000); Haitian Ctr. for Human Rights v. United States, Case 10.675, Inter-Am. C.H.R., Report No. 51/96, OEA/Ser.L/V/II.95, doc. 7 rev., at 550 (1997).

118. These two cases do not yet have formal admissibility reports.

119. Sánchez v. United States, Petition 65/99, Inter-Am. C.H.R., Report No. 104/05, OEA/Ser.L/V/II.124, doc. 5 (2005) (found inadmissible).

120. Shibayama v. United States, Petition 434-03, Inter-Am. C.H.R., Report No. 26/06, OEA/Ser.L/V/II.127, doc. 4 rev. 1 (2007).

121. Poor People's Econ. Human Rights Campaign v. United States (1999) (petition dismissed without prejudice for failure to identify individual victims).

122. Gonzales v. United States, Petition 1490-05, Inter-Am. C.H.R., Report No. 52/07, OEA/Ser L/V/II 128, doc. 19 (2007).

123. In this case, no public record of the filing is maintained.

124. These defects most frequently stem from petitioners' conflation of the case-based and promotional competences of the Commission, and an effort to extract strong, absolutist human rights statements from it without framing the controversy as a concrete justiciable case. See Tara J. Melish, Rethinking the "Less as More" Thesis: Supranational Litigation of Economic, Social, and Cultural Rights in the Americas, 39 N.Y.U. J. INT'L L. \& POL. 171, 207-74 (2006) (discussing common jurisdictional errors in framing contentious claims).

125. Although earlier cases had been lodged against the United States, it was in 1977 that the first case to proceed to a merits decision was submitted. See "Baby Boy" v. United States, Case 2141, Inter-Am. C.H.R., Res. No. 23/81, OEA/Ser.L/V/II.54, doc. 9 rev. 1, I 1 (1981). The United States extensively briefed this abortion-related case, using the regional instruments' travaux préparatoires to support its argument that regional norms protecting the right to life did not proscribe abortion absolutely, but rather allowed it to proceed under reasonable state regulation. 
nonetheless consistently address both the admissibility and merits of the underlying claim. The United States today substantively briefs and argues all questions posed by alleged victims and their representatives at each stage of case-based proceedings ${ }^{126}$ at the Commission's Washington, D.C. headquarters, at times arriving with full interagency delegations of experts in the distinct fields under consideration. ${ }^{127}$ It increasingly also invites local or state authorities in whose jurisdiction the alleged violation took place.

At the same time, while the United States hastens to emphasize that the final recommendations of the Commission are in fact just that--nonbinding recommendations-it likewise takes measures to consider the propriety of those recommendations and, to the extent state agency behavior is implicated, to give state agents the opportunity to independently consider and give effect to the Commission's conclusions and recommendations. Similar to the practice of other federal nations, decisions of the regional body are procedurally transmitted to the responsible federal department or agency and/or state attorneys general for follow-up, within the bounds of their responsibilities, competence, and discretion. ${ }^{28}$ In this sense, the U.S. State Department treats the Commission's recommendations in much the same way it treats ICJ decisions that affect state and local agents: it transmits the recommendations or decision to the competent authority, leaving it to themin function of federalism considerations-to determine the appropriate response under the circumstances. ${ }^{129}$ Speaking on the issue most recently in Medellin, the U.S. Supreme Court has appeared to endorse this approach. ${ }^{130}$

The United States responds in a similar way to requests for precautionary measures, whether by the Inter-American Commission or U.N. treaty bodies, such as the CERD Committee. ${ }^{131}$ Precautionary measures are urgent interim measures of protection designed to prevent the occurrence or continuance of alleged human rights abuses that threaten irreparable harm, particularly until the merits of the underlying claim is considered. They are

126. This includes pre-admissibility, admissibility, merits, and follow-up/compliance stages. With respect to the latter, the United States attended its first follow-up meeting in March 2007 to discuss compliance with the IACHR's recommendations. See Dann v. United States, Case 11.140, Inter-Am. C.H.R., Report No. 75/02, OEA/Ser.L/V/II.117, doc. 1 rev. (2002).

127. This is particularly true in cases dealing with national security issues.

128. Hill Interview, supra note 65 .

129. For a discussion of the U.S. response to ICJ provisional measures and merits decisions in the Breard, LaGrand, and Avena cases, see Murphy, supra note 12, at 50, which recalls that the "initial fall-out from the decisions on the merits in LaGrand and Avena is a story of the federal government encouraging the various states to take into account the decisions of the International Court, without actually telling the states that they must do so as a matter of federal law"; and id. at 49, which notes that the United States "sought to implement [provisional measures] . . . principally by encouraging the commutation of death sentences of the relevant convicts by governors or parole boards" and by "embark[ing] on an aggressive campaign to educate and train state law enforcement officers regarding obligations arising under the Vienna Convention, to the point of printing cards that officers were to carry with them and read out when arresting an alien."

130. Medellín v. Texas, 128 S. Ct. 1346 (2008).

131. The CERD Committee issued an "urgent action" request under its early-warning procedure to the United States in March 2006 with respect to the Western Shoshone Peoples of the Westem Shoshone Nation, giving the United States four months to respond on the measures it has taken in response. The United States has responded both in writing directly to the Committee and in Annex II of the U.S. CERD Report 2007, supra note 37, in which it provides background information on the case and a review of U.S. responses to the underlying claim over the years. 
issued based on a prima facie assessment, without prejudgment on the underlying merits, of written communications that suggest abuse may be occurring. ${ }^{132}$ While the United States regularly contests the competence of treaty bodies to issue such measures, the State Department nonetheless follows a policy of formally transmitting requests for precautionary measures as an informational notice to the appropriate attorney general or responsible federal agency. ${ }^{133}$ It also engages in associated hearings on the propriety of interim measures and on follow-up thereto, reporting on the measures it has taken to ensure precautionary measure requests are brought to the attention of the relevant body or bodies and, where compliance follows, on the steps taken by that body in response to the measures. Although far from the norm, federal and state agents have on occasion complied with precautionary measure requests issued by the Inter-American Commission. ${ }^{134}$

In sum, while the United States asserts that these contentious complaints procedures generate nothing more than recommendations for the United States to take under advisement-and participates in associated proceedings expressly on that basis-it nonetheless treats the process as a formal, adjudicatory one. ${ }^{135}$ It actively engages in all stages of proceedings, employing the full set of procedural rights available to it to defend U.S. policy interests within the jurisdictional constraints of the Commission's competence. Where defects are identified, processes are at times initiated to consider whether further measures are necessary to address the underlying concern. ${ }^{136}$ This is true of both individual complaints procedures under the

132. See, e.g., Commission Rules, supra note 106, art. 25 ("The granting of such measures and their adoption by the State shall not constitute a prejudgment on the merits of a case.").

133. Hill Interview, supra note 65. Such transmittals do not propose or encourage any particular action, but are sent to the relevant authority for that authority to respond to in its discretion.

134. See, e.g., Ramos v. United States, Case 12.430, Inter-Am. C.H.R., Report No. 1/05, OEA/Ser.L/V/II.124, doc. 7, I 89 (2005). The decision noted the U.S. indication that a federal district court judge in Texas had postponed setting an execution date in light of the petition before the Commission and its request for precautionary measures. "The Commission observes that this arrangement has given practical effect to the Commission's precautionary measures by preserving $\mathrm{Mr}$. Moreno Ramos' life and physical integrity pending the Commission's consideration of his complaint, and the Commission commends the efforts taken within the Texas judicial system to preserve $\mathrm{Mr}$. Moreno Ramos' right of effective access to the inter-American human rights system." Id.

135. Notably, upon submission of the Baby Boy case, "Baby Boy" v. United States, Case 2141 , Inter-Am. C.H.R., Res. No. 23/81, OEA/Ser.L/V/II.54, doc. 9 rev. 1 (1981), to the IACHR in 1977, four members of the U.S. House of Representatives sent a letter to the IACHR in 1979, "in a spirit of cooperation and with the intent of furthering the work of the Commission," requesting an opinion on "whether, if the United States loses, it would be subject to trade and diplomatic sanctions similar to those imposed upon Cuba by the O.A.S. following, and partially on account of, the human rights violations of the Castro regime?" It also requested suggestions on "how legislation might be shaped in order to eliminate any doubts as to U.S. compliance with IACHR standards in this regard." Id. I 19.

136. In other instances, the United States will indicate that it is taking measures to address the issue even while asserting that the Commission lacks competence to consider it. See, e.g., Medina v. United States, Case 12.421, Inter-Am. C.H.R., Report No. 91/05, OEA/Ser.L/N/II.124, doc. 5, 743 (2005) (asserting the Commission's lack of competence over the Vienna Convention on Consular Relations, but submitting nevertheless that the United States takes its obligations thereunder "very seriously and has since 1998 undertaken an intensive, on-going and now permanently institutionalized effort to improve compliance by federal, state and local government officials . . . includ[ing] the publication of a 72-page brochure on Vienna Convention requirements as well as a pocket reference card[] for arresting officials and a training video"). 
jurisdiction of the Inter-American Commission and the collective complaints mechanism of the ILO, in which U.S. engagement is equally extensive. ${ }^{137}$

\section{Other Promotional Mechanisms}

The United States also engages with U.N., OAS, and ILO treaty bodies in other noncontentious ways aimed at facilitating more robust human rights promotion at the domestic level. This may include coordinating with civil society on treaty-based requirements to prepare national programs of action to give treaty commitments domestic effect ${ }^{138}$ or issuing invitations to U.N. and OAS special rapporteurs and independent experts to come to the United States to undertake onsite visits or otherwise discuss issues under their special mandates. The United States has, for example, authorized and cooperated with the Inter-American Commission as it has undertaken onsite visits to Florida, Puerto Rico, New York, California, Kansas, Pennsylvania, Louisiana, and Texas to look into alleged abuses in state and federal detention facilities and with respect to migrant laborers and their families. ${ }^{139}$ U.S. cooperation is also expected should the Commission take up pending proposals to investigate other alleged abuses in the United States, such as housing discrimination and inappropriate use of electro-shock weapons by local police forces.

Similarly, the United States regularly accepts and facilitates country visits by U.N. special rapporteurs and independent experts who request invitations to visit the United States to engage in constructive dialogue with federal and state officials, NGOs, and civil society more broadly-most recently by the U.N. special rapporteurs on the subjects of protecting human rights while countering terrorism, ${ }^{140}$ human rights of migrants, ${ }^{141}$ and racial discrimination. Such U.N. experts are mandated to develop a regular dialogue with relevant governmental and nongovernmental actors, to exchange information, make recommendations, and identify and promote best practices on measures to respect and ensure fundamental human rights. Consistent with the U.S. approach to periodic reporting processes, U.S. officials have at times

137. As of January 2008, the ILO Committee on Freedom of Association has decided fortynine cases involving the United States, cases in which it frequently recognizes the United States's reliable and engaged participation in proceedings. For decisions, see supra note 107

138. ILO Convention 182, for example, requires ratifying states to develop a National Program of Action on ensuring child labor rights. ILO Convention 182 Conceming the Prohibition and Immediate Action for the Elimination of the Worst Forms of Child Labor art. 3, June 17, 1999, S. TREATY DoC. No. 106-5, 38 I.L.M. 1207 (1999), available at http://www.ilo.org/public/english/ standards/relm/ilc/ilc87/com-chic.htm. The U.S. government initiated a process of review with civil society organizations, but ultimately concluded that no additional measures were necessary.

139. For a list of all IACHR onsite visits, see Inter-American Commission on Human Rights, On-site Visits of the IACHR, http://www.iachr.org/visitas.eng.htm (last visited Apr. 21, 2009).

140. Press Release, Office of the High Comm'r for Human Rights, Special Rapporteur on the Rights of Migrants To Visit United States, U.N. Doc. HR/07/04 (Apr. 27, 2007) (announcing a U.S. invitation for a country visit in May 2007).

141. See Eliane Engeler, Associated Press, U.N. Rights Expert To Probe U.S. Treatment of Illegal Immigrants, DALLAS MORNING NEws, Apr. 27, 2007, available at http://www.dallasnews.com/sharedcontent/APStories/stories/D8OOU6501.html (reporting on U.S.facilitated visit in May 2007, with scheduled stops in California, Arizona, Texas, Florida, Georgia, New York, and Washington, D.C.). The U.N. expert was, however, denied access to certain facilities in Texas by local authorities. 
noted that special rapporteurs, through the noncontentious dialogue they engender with a diversity of domestic governmental and nongovernmental actors, represent one of the most promising ways of promoting change within the United States. ${ }^{142}$

\section{INTEREST MANAGEMENT: THE PUSH-PULl OF DOMESTIC AND FoREIGN POLICY AGENDAS}

As the above examination reveals, U.S. engagement with international human rights treaty bodies is quite robust. The operative question, then, is how this level of engagement can be reconciled with popular notions that the United States actively resists the domestic application of human rights norms and thumbs its nose at human rights treaty body regimes. The explanation, I argue, lies in interest management. Specifically, it resides at the intersection of domestic and foreign policy pressures, and the mediating postures the United States employs to steer a middle course through them. As with all international tribunals, engagement with human rights bodies involves important push-pull dynamics among a plurality of interest groups, with some urging greater engagement (the "push toward" factor) and others resisting engagement (the "pull away" factor). These push-pull vectors operate simultaneously at the foreign policy level and at the domestic policy level. The U.S. position has modulated within these countervailing tendencies over time, resting at momentary middle grounds within the four corners of the dynamic ${ }^{143}$ as interest politics change and distinct strategic opportunities evolve.

What appears clear, however, is that the United States is moving decisively toward greater engagement with international human rights treaty bodies. This shift is due both to growing pressures to engage at the foreign policy level and to a gradual diffusion of interests in domestic constituencies opposed to engagement. The net effect of the two dynamics, both accelerating since the 1990s, is an ever more robust engagement policy, albeit one that operates within clearly parametered constraints that represent the continuing power of "pull-back" interests.

While the motivations for each shift are independent of each other, their effects are mutually reinforcing and equally constitutive of the parameters of U.S. human rights policy. To demonstrate the various levers in this interestmanagement process, the following two sections look, respectively, at the push-pull dynamic as it plays out, first, at the foreign policy level between "realist" and "institutionalist" persuasions in the foreign policy establishment

142. Hill Interview, supra note 65 ; cf. Alston, supra note 90 (noting assumption that a constructive dialogue between treaty bodies and state parties may be the most productive means of prompting a government to take action).

143. Viewed diagramatically, this dynamic may be seen as operating on a plane with domestic and foreign policy interests along one axis and push-pull tendencies along another. The U.S. policy position locates itself within this four-comered plane at convergence points along the various and shifting vectors. 
and, second at the domestic policy level between groups I call "insulationists" and "incorporationists."

Because these labels are so important to the analysis, it should be emphasized that the four corresponding groups are neither ideologically based nor exclusive in their membership. Rather, each bundles adherents to one of four distinct instrumental approaches to interest achievement, each directed to fostering a political environment most conducive to a given foreign or domestic policy agenda. Their memberships are thus variable and politically contingent, with adherents straddling or moving into or out of groupings depending on the precise issue at stake and shifting appreciations of policy opportunities.

\section{A. Foreign Policy Interests: Net Push Toward Greater Treaty Body Engagement}

Foreign policy pressures have long been determinative in influencing the shape and scope of United States human rights policy. Evident since at least the $1950 \mathrm{~s}$, when the international human rights regime was first emerging, ${ }^{144}$ this influence is even more pronounced today as that regime has matured into a set of legitimacy-bestowing international instruments and institutions. Two intellectual camps have been most determinative in this regard, both heavily represented in the U.S. foreign policy establishment. They include groups frequently referred to as "realists" and "institutionalists."

Realists include those who, following either classical or neostructural versions of international relation's realism theory, ${ }^{145}$ understand state behavior as influenced by one of two realpolitik determinants: the raw power of a more powerful state or an objective expectation of material benefit, such as trade benefits, economic assistance, or debt reduction. Realists in the U.S. foreign policy establishment thus reject the usefulness of international institutions or norms, seeing them as mere window dressing for real power and interest. They seek instead to preserve the unconstrained prerogative of the United States, as a world superpower, to protect national interests and respond to foreign threats by all available means, including unilateral power wherever necessary.

Institutionalists, on the other hand, see greater instrumental utility in engaging actively with both international institutions and global normsincluding human rights norms. While they, too, believe that states act

144. See Carol anderson, Eyes off the Prize: The United Nations and the African

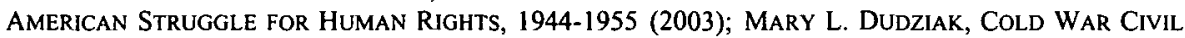
RIGHTS: RACE AND THE IMAGE OF AMERICAN DEMOCRACY 79-202 (2000) (documenting the determinative nature of diplomatic and foreign policy pressures in influencing federal response to the U.S. civil rights movement in the 1950 s and 1960s).

145. For the most influential classical accounts of realism, see HANS MORGENTHAU, POLITICS among Nations: The Struggle for Power and Peace (1955); Thomas Schelling, The Strategy OF CONFLICT (1960); and KenNETH WaLTZ, TheORY OF INTERnational Politics (1979). More recent "neorealist" scholarship has sought to refine these classical understandings by drawing upon concepts in game theory and law and economics. See JaCK Goldsmith \& ERIC POSNER, The Limits of INTERNATIONAL LAW (2005). 
exclusively in accordance with their instrumental interests, ${ }^{146}$ they see these interests as being increasingly interwoven with participation in international cooperative, peacebuilding, and dispute-resolution institutions. ${ }^{147}$ U.S. engagement with international institutions thus constitutes for institutionalists an important and instrumental foreign policy tool for promoting and defending U.S. interests abroad, while conferring key reputational benefits, ever more salient in global politics, particularly in the international human rights field. ${ }^{148}$

While realists dominated U.S. human rights policy during the Cold War, ${ }^{149}$ and remain highly influential in the foreign policy establishment today, institutionalists have gained increasing prominence over the last two decades with the dramatic proliferation of international institutions and rapid expansion of the international human rights architecture. Within this context, the push-pull dynamic over U.S. human rights policy as a foreign policy objective has shifted determinatively toward institutionalists. For this group, human rights treaty body engagement serves two primary strategic foreign policy goals today: first, renewal of U.S. moral leadership in multilateral settings and, second, promotion of human rights and democratic reforms in other countries. Both are directed to furthering national security and global public order objectives, independent of any domestic policy implication.

First, institutionalists appreciate that the international standing of U.S. diplomats and their ability to lead in international processes of global dispute resolution are compromised by the nation's failure to ratify core human rights treaties and engage in their supervisory procedures. This failure, which has left the nation increasingly in the company of rogue or failed states, ${ }^{150}$ renders it out of step with its democratic partners and subjects it to charges of hypocrisy by less democratic nations where the United States seeks human rights improvements or security safeguards. ${ }^{151}$ On a practical level, this impairs the United States's ability to accomplish its national security and other global security priorities within multilateral settings, at times making disagreement with the United States a "principled" human rights stand in itself

146. Harold Hongju Koh, Why Do Nations Obey International Law?, 106 YALE L.J. 2599, 2649 (1997) (book review) (referring to both as "instrumental interest theories").

147. See, e.g., Robert O. Keohane, After Hegemony: CoOperation and Discord IN the WORLD POLITICAL ECONOMY (1984).

148. Andrew T. Guzman, A Compliance-Based Theory of International Law, 90 CAL. L. REV. 1823 (2002) (suggesting a reputation-based model of state compliance with intemational law).

149. See generally Hartmann, supra note 52.

150. The United States stands alongside Somalia, a nation lacking a functional govemment, as the only of 194 U.N. member states not to have ratified the CRC. The United States stands among only eight not to have ratified the CEDAW.

151. See, e.g., Harold Hongju Koh, Why America Should Ratify the Women's Rights Treaty (CEDAW), 34 CASE W. RES. J. INT'L L. 263, 269 (2002) ('[F]rom my direct experience as America's chief human rights official, I can testify that our continuing failure to ratify CEDAW has reduced our global standing, damaged our diplomatic relations, and hindered our ability to lead in the international human rights community. ... In particular, our European and Latin American allies regularly question and criticize our isolation from this treaty framework both in public diplomatic settings and private diplomatic meetings."); Moravcsik, supra note 2, at 194 (citing Patricia Derian, Assistant Sec'y of State, Bureau of Human Rights and Humanitarian Affairs, Statement in U.S. Congress: International Human Rights Treaties (Nov. 1979), which affirmed to the Senate Foreign Relations Committee that "failure ... to ratify [ICCPR, ICESCR, CERD, and CAT] has a significant negative impact on the conduct of [U.S.] human rights policy," undermining its "credibility and effectiveness"). 
for nations. ${ }^{152}$ In this sense, ratification and engagement serve as tools through which the United States can reseat itself within the "international community," reassert its moral leadership role, and hence better promote its national security agenda in multilateral settings, where most international work gets done. For institutionalists, this has been a particular priority following the widely internationally condemned unilateral actions taken by the United States following the $9 / 11$ terrorist attacks.

The second factor, most commonly articulated by the U.S. State Department, involves recognition that full compliance by the United States with international human rights treaty body procedures increases the visibility and legitimacy of the procedures themselves, ratcheting up expectation levels for their regular and concerted use, and thereby prodding other states to take the procedures more seriously. Indeed, U.S. executive agencies recognize that human rights treaty bodies-by providing an international spotlight for gross abuses, giving voice to individuals and civil society groups seeking greater human rights protections and transparency at home, and providing legitimacy to domestic human rights and democracy movements-have initiated important conversations and processes in countries around the world, particularly in transitional states. ${ }^{153}$ They also recognize that while the United States's failure to ratify specific treaties has not likely caused other states to forego ratification, it may embolden some to turn ratification into an empty political act used as a rhetorical device to claim greater commitment to human rights than the United States without making corresponding changes in their policies and practices at home. ${ }^{154}$

In this sense, while the foreign policy establishment may remain skeptical, or at best agnostic, about the usefulness of engagement for the U.S. domestic human rights record, it nonetheless fully recognizes and values the importance of treaty body engagement for promoting human rights and democracy in less democratically stable states. ${ }^{155}$ By actively and constructively engaging with these procedures-through high-level government participation, comprehensive reporting, well-prepared and legally argued oral and written interventions, civil society participation, and a high degree of transparency ${ }^{156}$ - the United States thus seeks, through its example, to encourage other states to do the same. It is, in this sense, constitutive of the

152. This became increasingly apparent in a growing number of votes at the United Nations during 2006. The same collective rejection was expressed in international elections in which U.S. nominees failed to be elected to international bodies for the first time in history. See International Law Commission, 2006 Election of the International Law Commission, http://untreaty.un.org/ilc/ 2006election.htm (last visited Apr. 21, 2009).

153. See White House, National Security Strategy of the United States of america (2006) (stating that supporting human rights treaty bodies is an explicit part of the U.S. National Security Strategy), available at http://www.state.gov/documents/organization/64884.pdf; U.S. DEP'T OF STATE, supra note 5, at viii-ix (setting out ten principles to guide U.S. human rights policy around the world, in recognition that NGOs "are essential to the development and success of free societies and that they play a vital role in ensuring accountable, democratic government").

154. With respect to the frequency of treaty ratification as an empty political act, see generally Hathaway, supra note 21 .

155. It serves, in this sense, to help restore a balance between ratifying nations whose formal treaty commitments find analogues in domestic policy and practice and those that do not

156. See supra Section III.A (identifying characteristics of U.S. engagement) 
United States's already heavy human rights investments in its broader national security agenda, a key strategy for promoting good practices in other states and hence contributing to global security as a whole.

These two general "push" factors appear to be the dominant influences motivating U.S. engagement policy with international treaty bodies. They are, however, blunted at the margins by certain "pull away" or "realist" tendencies. These, led by foreign policy-focused national security entities such as the National Security Council and Department of Defense-with the legal buttress of the U.S. Justice Department ${ }^{158}$ - tend to be little concerned about most of what human rights tribunals do, and hence have less interest in U.S. engagements with them on the whole. They are more concerned with the implications of U.S. engagement with other international courts and tribunals, such as the International Criminal Court (ICC) or the International Court of Justice (ICJ), that more directly touch on state-to-state national security and international defense prerogatives. This follows from the fact that human rights tribunals do not tend to deal directly with interstate or transjurisdictional disputes that may involve threats to national security or other interests emanating from abroad ${ }^{159}$ - for which realists seek to maintain a supple and unconstrained response capability. Rather, they deal exclusively with U.S. conduct vis-à-vis persons subject to the United States's own jurisdiction. As such, the geopolitical calculations of engagement tend to be distinct from, and less sensitive than, those related to most other international tribunals.

Realist tendencies nonetheless recognize that too full an engagement with human rights treaty bodies might function in practice to constrain U.S. warmaking or defense functions, especially as exercised abroad. Foreign policy realists thus pull back in areas where this might occur. That is, while institutionalists, for the reasons noted above, tend to prevail on the question of engagement once treaty ratification has been effected, their realist counterparts police the boundaries of human rights supervision, "pulling back" against the institutionalists' "push forward" wherever human rights supervision may conceivably circumscribe U.S. national security discretion and war-related undertakings.

The United States has mediated these push-pull concerns by adopting an engagement policy that participates fully in human rights treaty body

157. In this respect, while some note that U.S. ratification has little effect on other states' decisions to ratify or not, see Moravcsik, supra note 2, at 192 (finding little empirical evidence to support common claim), the level and scope of U.S. participation in treaty body processes or lack thereof can be expected to have a notable effect on the scope of other states' participation, given the ratchet effect it has on community expectations.

158. The U.S. Department of Justice under the Bush administration played a central role in crafting legal arguments to resist international engagement and provide justification for "war on terror" policies that often put the U.S. at loggerheads with the rest of the world. In so doing, it has increasingly been at policy odds with the U.S. Department of State. See Neil Lewis, Justice Dept. Under Obama Is Preparing for Doctrinal Shift in Policies of Bush Years, N.Y. Times, Feb. 2, 2009, at Al4.

159. Interstate complaint mechanisms, though rarely used, are in fact established under most human rights treaties. The United States has recognized the competence of the Human Rights Committee to examine interstate complaints against it under the ICCPR. See 138 CONG. REC. S4781-01 (daily ed. Apr. 2, 1992). 
mechanisms, except to the extent they purport to address extraterritorial concerns or matters that overlap with international humanitarian law or the law of armed conflict. That is, the United States has adopted a foreign policy position that supports active U.S. engagement with human rights treaty bodies, in all but these two sensitive areas defined as beyond the jurisdictional competence of international human rights supervision. While these positions put the United States in an increasingly adversarial posture vis-à-vis human rights treaty bodies, given extraterritorial abuses committed in response to the $9 / 11$ terrorist attacks and the U.S. war against Iraq and Afghanistan, ${ }^{160}$ they may be seen as a core mediating technique between U.S. institutionalist and realist positions with respect to achieving its varied foreign policy objectives.

\section{B. Domestic Policy Interests: From Net Pull to Push, the Evolution of Domestic Social Struggles}

The above foreign policy considerations have dominated in determining current U.S. engagement modalities with human rights treaty bodies over the last decade. The prior question of whether the United States will in fact ratify a given treaty, and thus open itself to treaty body engagement, remains a decision in which domestic politics are distinctly paramount. The push-pull dynamic on U.S. decisionmakers at this level functions not between foreign policy institutionalists and realists, but between domestic groups we may term "insulationists" and "incorporationists." The former seek to insulate domestic law from the influence of international human rights constructions, finding a domestic environment free from human rights methodologies and migrations more amenable to achieving their substantive political policy preferences. They oppose U.S. ratification of human rights treaties and vigorously object to the use of human rights norms by domestic courts. Incorporationists, by contrast, find the mediating influence of international human rights law on domestic politics helpful to their domestic policy agenda, which generally favors broader individual rights interpretations, with fewer permissible restrictions. They thus seek to incorporate international human rights norms and human rights methodologies into domestic law and decisionmaking processes, through treaty ratification, local monitoring and interpretation initiatives, treaty body engagement, grassroots mobilization, judicial oversight, and direct implementing legislation at local, state, and federal levels.

This push-pull dynamic has played out in virtually every domestic social struggle since the international human rights regime first emerged sixty years ago. Thus, the civil rights era demands of incorporationists in the 1950s and 1960s for the federal government to ensure respect for international human rights guarantees of racial equality were quickly countered by insulationists' 
initiatives to launch "states' rights" movements, ${ }^{161}$ red-baiting campaigns against rights advocates (and internationalism generally), and the fateful Bricker Amendment, a concerted attempt to constitutionally insulate domestic law from all treaty-related modifications. ${ }^{162}$ These insulation initiatives, intersecting with Cold War politics, led to a series of actions and political compromises that ensured that human rights remained off the domestic policymaking agenda for the next quarter-century. Since the 1970s, this dynamic has played out with similar intensity over "family values," abortion, and personal lifestyle choice debates, with incorporationists seeking broad human rights statements from international treaty bodies to incorporate into domestic advocacy and litigation strategies and insulationists seeking to foreclose all reference by domestic legislatures and courts to international decisions or comparative rights jurisprudence. ${ }^{163}$

In this politicized struggle over the control of legal rights meaning, domestic policy insulationists-fewer in numbers, but better in organization, funding, and insider/beltway political contacts-have historically been dominant. The reasons for this, at least from the perspective of treaty ratification, are reviewed by Professor Moravcsik in his discussion of the "U.S. human rights paradox." They center on two factors: first, the extreme decentralization and fragmentation of U.S. political institutions, which makes them uniquely amenable to veto-group politics; and, second, a strong conservative minority that has consistently utilized veto players, most notably in the U.S. Senate, to achieve its insulationist agenda. ${ }^{164}$ Indeed, employing a culturally resonant rhetoric sounding in constitutional democracy, this minority has historically been successful in rallying partisan affiliates and mobilizing veto players to block ratification of human rights treaties, either by bottlenecking them in the Senate Foreign Relations Committee or by foreclosing their ability to achieve supermajority advice and consent in the full Senate.

The powerful political and financial lobby of these interest groups, and their unique control over veto players in the political process-particularly over Republican majorities in the Senate-explains the historic failure of the United States to ratify human rights treaties apace with similarly minded nations, those equally committed to domestic human rights guarantees. ${ }^{165} \mathrm{It}$ nonetheless fails as a reliable explanatory framework for predicting U.S. human rights engagements in the twenty-first century. Such an explanation

161. These movements, which included the founding of a "states' rights" political party, sought to insulate local segregationist and abusive policies from the illumination provided by federal constitutional, statutory and treaty law.

162. For an animating description of the process through which the proposed constitutional amendment (and a watered down version of it) failed, see ANDERSON, supra note 144, at 221-41.

163. See, e.g., H.R. Res. 97, 109th Cong. (2005) (seeking to preclude domestic courts from referring to "judgments, laws, or pronouncements of foreign institutions" in determining the meaning of U.S. laws); H.R. Res. 568, 108th Cong. (2004).

164. Moravcsik, supra note 2 , at $186-90,197$.

165. It also helps to explain why the United States, after ratifying the ICCPR, CERD, and CAT in 1992 and 1994, did not ratify the CRC and CEDAW between 1994 and 2006, when Republicans held majorities in the Senate and "family values" groups were actively lobbying beltway veto players against ratification. 
would have to account for three closely related facts: one, U.S. ratification of an increasingly broad spectrum of human rights treaties in the 1990s that failed, over time, to generate or sustain strong issue-specific oppositional lobbies (including the ICCPR, CERD, CAT, and child-protective labor rights treaties); two, active U.S. engagement in the international supervisory regimes corresponding to these treaties, including in areas of substantive overlap with nonratified treaties, such as the CRC, CEDAW, and ICESCR; and, three, the altered opportunity structure that both of the above factors create for domestic advocates-i.e., those pushing for greater engagement, and those pulling away from it-as they perpetually recreate and evolve their strategies to better achieve distinct substantive policy preferences in changing political environments.

That is, a fully explanatory description of U.S. human rights politics must account not only for the structural potential for mobilized political lobbies to block treaty ratification. ${ }^{166}$ It must account as well for the shifting incentive structure for them to do so over time and the relative receptivity of the population (and hence potential veto players) to traditional insulationist arguments. As these environmental factors change, so too does the importance of "extreme decentralization" as a structural condition favoring-rather than disfavoring-insulation. ${ }^{167}$ At the same time, insulationism, like incorporationism, has always been an instrumental strategy for its proponents, supported to create a domestic political environment most conducive to particular policy agendas. As soon as it ceases to bring comparative advantage, it will be discarded and replaced by a new set of strategies and supporting ideologies. This is precisely what we are beginning to see today.

The United States is thus faced in the twenty-first century with a new set of domestic pressures in its human rights engagement policy. It is no longer exclusively a push-pull dynamic between "liberal" and "conservative" interest groups, with the latter consistently prevailing--as they did from the $1950 \mathrm{~s}$ to the 1980s-through their unique ability to block ratification of human rights treaties, and hence, together with a particular brand of politically resonant rights absolutism, preempt human rights conversations from deepening domestically. Rather, with U.S. ratification of core human rights treaties in the $1990 \mathrm{~s}$, it is increasingly becoming a push-push dynamic in the twenty-first century. That is, liberal interest groups, true to their incorporationist heritage, continue to push for greater U.S. engagement with human rights treaties and treaty bodies as a means of bringing domestic law, policies and practice more fully into line with international human rights norms-norms they have spent decades constructing. ${ }^{168}$ Conservative interest groups, for their part, faced with a growing incorporationist reality, have increasingly realized that insulationism alone may not be helpful to their agendas, particularly as they

166. The mere existence of a vocal conservative minority and institutional amenability to veto politics as a treaty-blocking option does not, in itself, speak to the utility of insulationist strategies to the conservative political agenda.

167. See Moravcsik, supra note 2; supra text accompanying note 164 .

168. Notably, they have often helped construct these norms in the mold of strong U.S. constitutional rights protections. 
relate to lifestyle, personal choice, parenthal rights, and "family values" issues. Many such groups are thus urging the United States not to disengage with international human rights bodies, but rather to more fully engagealbeit with a distinct agenda. ${ }^{69}$ That is, they do not seek the domestication of presently recognized international norms, as do liberals, but rather-in a strategic reversal of process-the internationalization of socially conservative rights constructions more amenable to their domestic policy agenda, which may then be subject to incorporation at some later date. Where opportunities emerge, traditional insulationists are increasingly using partisan political connections to press the U.S. diplomatic (and legislative) corps to undertake this agenda on their behalf. ${ }^{170}$

Because this transition is so important for understanding current U.S. human rights politics, it is useful to highlight below the constitutive processes that led to it. The techniques the United States adopts to mediate between these dueling push-push pressures will be taken up more fully in Part V.

\section{Diminishing U.S. Receptivity to Insulationism}

Historically, insulationism has been employed by socially or politically conservative groups as a way to bypass the mobilizing influence of human rights law on those wishing to effect equality or dignity-based change in the U.S. social structure. Because such change is rhetorically consistent with the promise of the U.S. Constitution-indeed, with the country's national narrative $^{171}$ - it has been necessary to create an ideational structure that pits international human rights law against U.S. constitutional democracy, framing the former as undemocratic and even anti-American. This is possible through a rhetorical manipulation of international human rights law that equates it with absolutist, externally defined policy outcomes, intrinsically and automatically superior to domestic determinations. In fact, both sides of the political spectrum have tended to rely on rights-absolutist constructions to appeal to their respective constituencies, one side affirming that international treaty law requires the immediate modification of domestic law to strictly conform to international treaty body views and policy preferences, the other that international law constructions conflict with deliberative democracy at home. ${ }^{172}$

It is in fact precisely this rights-absolutism that is responsible for the contentiousness of human rights treaty law engagements as a matter of U.S. domestic politics and, specifically, the historic ability of veto politics to successfully block human rights treaty ratifications. That is, opponents have mobilized influential veto players by representing human rights law as a

169. See infra Subsection IV.B.3.

170. Id.

171. See Jack M. Balkin, Brown as Icon, in WHAT BROWN V. BOARD OF EDUCATION SHOULD HAVE SAID 3, 5 (Jack M. Balkin ed., 2001) (describing as the "Great Progressive Narrative" that widely held and often repeated story of deep resonance in American culture, which sees America's basic ideals of liberty and equality as promises for the future to be achieved eventually through historical struggle and acts of great political courage).

172. For judicial and legislative examples of the latter, see supra note 68. 
doctrine of foreign-determined meaning imposed on nonconsenting domestic populations. Nationalistic urgency is then tied to ratification-blocking campaigns by asserting that ratification will force the United States to adopt a set of externally defined policies that are morally or socially objectionable to a large segment of the population, particularly through the countermajoritarian intervention of "activist" courts. In the 1950s and 1960s, this tactic took the form of imagining U.N. bodies as socialist-inspired institutions that would force communities to desegregate their schools, eateries, pools, and public accommodations and lead to widespread miscegenation ${ }^{173}$-issues that could mobilize powerful domestic constituencies against human rights treaties in that era. By contrast, assertions are today made that adhesion to currently unratified treaties, like the $\mathrm{CRC}$ and CEDAW, will require immediate mandatory legalization of same-sex marriage, provision of abortion and contraception on demand, decriminalization of prostitution, the turning over of child-rearing to the state, and other measures that could not currently be achieved through national-level democratic processes alone. ${ }^{174}$

It is this caricatured vision of human rights treaty law-one permitting of no national discretion in the crafting of "appropriate" policies-that gives rise and animating force to "national sovereignty," "states' rights," and other "rights-cultural" objections. ${ }^{175}$ These objections, though plainly instrumental given the subsidiary structure of human rights law, have high political traction in the U.S. popular mindset and hence are effective mobilizing tools for capturing key veto players to block ratification when perceived as politically advantageous.

This blocking process reliably works, however, only to the extent that a politically influential minority can be convinced, or can convince core constituencies, of two consequences: one, that ratification will compel the immediate adoption of laws and policies determined by external (not domestic) decisionmakers; and, two, that such policies are socially or morally repugnant or otherwise contrary to group interests. Both propositions have become increasingly difficult to sustain over the last decade, as the U.S. ratification record reveals.

First, the idea that human rights treaty ratification will compel the United States blindly to adopt externally defined policies is today unsupportable. As a legal matter, the United States has removed all basis for

173. See, e.g., William Fleming, Danger to America: The Draft Covenant on Human Rights, 37 A.B.A. J. 739, 794-99 (1951) (claiming that the Draft Covenant on Human Rights is the "perfect embodiment of . . . unmitigated socialism"); Frank E. Holman, International Proposals Affecting SoCalled Human Rights, 14 LAW \& CONTEMP. PROBS. 479, 483 (1949) (claiming that the Universal Declaration of Human Rights will force the United States to allow interracial marriages).

174. See Phyllis Schlafly, Time To Unsign CEDAW, Feb. 14, 2007, http://www.eagleforum.org/column/2007/feb07/07-02-14.html; see also Juliet Eilperin, New Drive Afoot To Pass Equal Rights Amendment, WASH. POST, Mar. 28, 2007, at A1 (citing parallel arguments against the passage of the Equal Rights Amendment-from a claim in the 1970s that it would compel public unisex bathrooms and a female military draft-to those in 2007 that it, like CEDAW, would compel courts to approve same-sex marriage and deny Social Security benefits for housewives and widows).

175. It also gives rise to academic critiques of human rights advocacy. See, e.g., David Kennedy, The International Human Rights Movement: Part of the Problem?, 15 HARV. HUM. RTS. J. $101(2002)$. 
doubt over the issue by adopting the consistent practice of attaching non-selfexecution clauses to human rights treaties upon ratification. ${ }^{176}$ Such clauses stipulate that any change to domestic law required by international treaty commitments must be implemented through the ordinary legislative process, in which federal, state, and local voices may all be heard, not through direct judicial constructions unmediated by "deliberative democracy." 177 This policy, directly responsive to rights-absolutist constructions that sustain "states' rights" and "national sovereignty" rhetoric, effectively removes the key mobilizing rationale behind policy-driven opposition to ratification initiatives. ${ }^{178}$ At the same time, it has become increasingly clear, as a factual matter, that U.S. ratification of the ICCPR, CERD, CAT, ILO Convention 182 , and the two CRC optional protocols-and submission to the jurisdiction of their supervisory treaty bodies-has not forced the United States to adopt extremist policies that were not fully vetted by domestic political processes. There is no reason to believe that this will not likewise be true with U.S. ratification of additional treaties, such as the CRC, CEDAW, and the ICESCR.

Second, given broad social, cultural, and attitudinal changes in the United States over the last two decades, domestic policy changes claimed to be required by human rights treaty ratification are not sufficiently unpalatable to U.S. interest groups in the twenty-first century to sustain veto politics for all but a small number of content-specific treaties. Such treaties are generally those associated with women's and children's roles in the family and workforce, including parental rights and women's and girls' access to contraception, abortion, and "integral health services." These issues-like those on sexual orientation, marriage, prayer, and Israel-are those on which socially conservative minority groups continue to hold powerful domestic sway. ${ }^{179}$ This narrowing environment in which veto politics can effectively function follows from the changing interest politics and shifting political alliances that social struggle and norm internalization have brought with time. Indeed, as the principal social struggles turned in the last half-century from race and Cold War divisions to "moral values" and "lifestyle choice" issues, old social alliances broke down and the treaty-opposition agenda narrowed, becoming more issue specific and less capable of mobilizing influential players across broad social sectors. At the same time, many politically and financially influential domestic groups-such as the U.S. business and legal

176. In providing its advice and consent to the ICCPR in 1992, for example, the Senate declared that "the provisions of Article 1 through 27 of the Covenant are not self-executing." 138 CONG. REC. S4781, at S4784 (1992). The Senate stated that the declaration was meant "to clarify that the Covenant will not create a private cause of action in U.S. Courts." S. REP. No. 102-23, at 15 (1992).

177. In its decision in Medellin v. Texas, 128 S. Ct. 1346 (2008), the Supreme Court appeared to adopt a different, more expansive interpretation of non-self-execution that does not conform to the Senate's stated intent, see supra note 176, in attaching such clauses to human rights treaties. Medellin, $128 \mathrm{~S}$. Ct. at $1356 \mathrm{n} .2$.

178. This concern over direct judicial enforcement of human rights treaty law tends to be the principle objection of opponents of U.S. human rights incorporation. See, e.g., Jack Goldsmith, Should International Human Rights Law Trump U.S. Domestic Law?, I CHI. J. INT'L L. 327 (2000).

179. Significantly, this sway was magnified in the eight years of the Bush II presidency, given the special access such groups had to the White House and formal positions of power. 
communities - that once reliably opposed incorporation have today become, for a diversity of self-interested and non-self-interested motivations, active proponents of U.S. ratification of human rights treaties. ${ }^{180}$ The U.S. business community, for example, has taken energetic part in ILO and other treaty drafting processes (particularly where child labor protections are at issue), actively lobbying the Senate Foreign Relations Committee for speedy ratification and attaining it even under strong Senate Republican majorities. ${ }^{181}$

Given the nature of the U.S. political structure, these shifting alliances have led to a predictable outcome: with broad national support for human rights treaty ratification generally, targeted proratification lobbying by certain influential groups, and veto players mobilizable only with respect to limited "family value" subject matters, the United States proceeded to ratify the ICCPR, CERD, CAT, and a variety of labor and child rights treaties in the 1990 s and early 2000s. It will not be long before additional treaties are ratified, particularly where coordinated civil-society ratification campaigns intersect with Democratic control of the U.S. Senate, as will be the case in 2009 and 2010.

\section{Creeping Incorporation, Despite Insulationist Obstruction}

At the same time, it has become increasingly clear that strategies focused on insulation alone-most notably, ratification blocking and the inclusion of a standard package of reservations, understandings, and declarations with treaty ratification ${ }^{182}$ - are no longer reliable in insulating the U.S. domestic system from human rights methodologies and migrations. This has resulted from the many innovative and constantly adapting strategies undertaken by incorporationists over the years, designed to circumvent the blocking potential of traditional insulationist tactics. While these traditional tactics have focused on top-down insulation, mobilizing federal veto players through rhetorical appeals to states-rights and federalism-based safeguards on localized experimentation, the new incorporationist strategies seek in fact to operationalize these appeals: they start at the grassroots and incorporate

180. The American Bar Association (ABA) was a powerful and highly influential opponent of human rights treaties in the late forties and fifties. See, e.g., Fleming, supra note 173 (citing arguments of the ABA President). Today it actively supports ratification of CEDAW, CRC, ICESCR and the American Convention, albeit with a standard set of reservations, understandings, and declarations (RUDs).

181. This was true with both ILO Convention 182 and the two optional protocols to the CRC, each ratified under Republican Senate majorities with the support of the U.S. business community. See, e.g., Letter from the American Apparel Mfrs. Ass'n et al. to Senator Jesse Helms and the Senate Foreign Relations Comm. (Sept. 23, 1999), available at http://www.uscib.org/index.asp ?documentID $=1352$ (providing the reasons that the U.S. business community, including the U.S. Chamber of Commerce and Business Roundtable, supports U.S. ratification). The U.S. business community has also become an influential supporter of universal health insurance in the United States. See, e.g., Jonathan Cohn, What's the One Thing Big Business and the Left Have in Common?, N.Y. TIMES, Apr. 1, 2007, § 6 (Magazine), at 45-49.

182. For the package of RUDs under the CERD, ICCPR, and CAT, see 140 CONG. REC. S7634-35 (daily ed. June 24, 1994); 138 CONG. REC. S4781-84 (daily ed. Apr. 2, 1992); and 136 CONG. REC. S17,486-92 (daily ed. Oct. 27, 1990). Of course, not all RUDs are necessarily aimed at insulation; many are required by legitimate constitutional constraints and are fully consistent, in both letter and spirit, with intemational law. 
upwards. In this regard, one must underscore that while "extreme decentralization" or "political fragmentation" has been identified as a structural factor of the U.S. political system that favors top-down insulation, ${ }^{183}$ it is-just as critically-a structural factor of the U.S. political system that favors bottom-up incorporation. ${ }^{184}$ The ability of the two in our Madisonian democracy to "resist and frustrate the measures of the other" 185 has been one of the defining characteristics of U.S. human rights politics from the late twentieth to early twenty-first centuries. This can be seen in a wide variety of modern incorporationist tactics.

First, with ratification of certain domestically popular human rights treaties impeded at the federal level by veto politics, incorporationists have gone straight to their local and state governments seeking direct localized incorporation, with growing success rates. With respect to CEDAW and the $\mathrm{CRC}$, for example, governmental bodies in scores of U.S. states, territories, cities, and localities have adopted resolutions or instruments endorsing the conventions or adopting them on behalf of their jurisdictions. ${ }^{186}$ These initiatives have at times been accompanied by innovative community-based supervision and other follow-up procedures to monitor local level progress in achieving treaty-related commitments and to ensure implementation of locally relevant solutions to the problems identified. Projects in San Francisco, Berkeley, New York City, Portland, Milwaukee, Pennsylvania, and Massachusetts have been particularly noteworthy, although forms of localized human rights incorporation are apparent at the grassroots level throughout the country. ${ }^{187}$ City and state governments are, in response, increasingly taking a human rights-based approach to community problem solving, including with respect to the few treaties that vocal conservative minorities continue to be able to block at the federal level. ${ }^{188}$

183. See Moravcsik, supra note 2, at 186-90, 197.

184. In view of this in the judicial field, William Brennan famously called upon state courts to continue to expand strong individual rights protections under state constitutions, given federal judicial "backsliding" in the 1970s. William J. Brennan, Jr., State Constitutions and the Protection of Individual Rights, 90 HARV. L. REV. 489, 489-504 (1977).

185. The Federalist No. 46, at 263 (James Madison) (Clinton Rossiter ed., 1961) (discussing U.S. federal structure); $c f$. Moravcsik, supra note 2, at 197 ("The institutional odds against any fundamental change [in U.S. human rights policy] in Madison's republic are high.").

186. See, e.g., Chi. City Council, Resolution, Feb. 11, 2009 (on file with author) (resolving to "advance policies and practices [that] are in harmony with the principles of the Convention on the Rights of the Child in all city [sic] and organizations that address issues directly affecting the City's children."); Koh, supra note 151, at 274 ("Far from CEDAW imposing unwanted obligations on local governments, local governments are in fact responding to the demands of their citizens, who have become impatient at the lack of federal action to implement these universal norms into American law.").

187. See, e.g., Martha Davis, Upstairs, Downstairs: Subnational Incorporation of International Human Rights Law at the End of an Era, 77 FORDHAM L. REV. 411 (2008); Stacy Laira Lozner, Diffusion of Local Regulatory Innovations: The San Francisco CEDAW Ordinance and the New York City Human Rights Initiative, 104 COLUM. L. REV. 768 (2004).

188. This is particularly true with respect to CEDAW and the CRC. The United States has also not ratified the ICESCR and American Convention. The reasons, however, do not appear to be veto politics, but rather simply the lack of any organized domestic constituency pushing strongly for ratification of either. That is, while there is no vocal minority actively obstructing ratification, nor is there yet any strong domestic advocacy movement pushing for ratification. 
Second, even where federal ratification is attained, non-self-execution clauses have posed a prima facie, if often overstated, dilemma for domestic human rights advocates. These jurisdictional clauses bar domestic courts from entertaining private causes of action arising directly under treaty law, requiring instead that independent causes of action be identified under U.S. statutory, constitutional, or common law. Incorporationists have responded by increasingly pressing domestic courts to apply human rights treaty law not directly, but rather indirectly - used as a nonbinding interpretive aid or source of persuasive authority in discerning meaning under independent private causes of action. ${ }^{189}$ U.S. courts, with their long historical pedigree of reference to international law, foreign practice, and foreign court judgments, have often been willing to adopt this approach, particularly with respect to state and federal constitutional provisions that are direct analogues to treaty-based norms, such as due process and cruel and unusual treatment or punishment. ${ }^{190}$ State courts, the principal protagonists in cooperative judicial federalism, may be especially amenable to such human rights migrations in interpreting state constitutional guarantees. This is particularly true where such guarantees have been directly influenced in their drafting by international human rights law ${ }^{191}$ or where they include normative protection for rights-such as those to health, education, welfare, or human dignity - that have no direct federal constitutional parallels and thus for which comparative foreign law and human rights sources are particularly useful. ${ }^{192}$ Although insulationist resistance to this judicial methodology remains sharp, ${ }^{193}$ the movement toward greater U.S. judicial reliance on transjurisdictional human rights dialogues is unmistakable; it represents an area of growing U.S. human rights incorporation of ratified, and even unratified, treaty law. ${ }^{194}$

Third, as with non-self-execution clauses, incorporationists have not been deterred by declarations or understandings attached to human rights treaties upon ratification that purport to affirm that U.S. laws are fully in compliance with treaty norms, and hence require no modification. Rather, incorporationists have persistently used treaty body procedures-particularly periodic reporting and contentious complaints-to draw attention to perceived gaps and deficiencies in U.S. law, policies, and practices and to press

189. In the U.S. Supreme Court's 2006 Term, all nine Justices endorsed the view that treaty interpretations by international tribunals were entitled to "'respectful consideration"” by U.S. courts. Sanchez-Llamas v. Oregon, 548 U.S. 331, 351 (2006) (quoting Breard v. Greene, 523 U.S. 371, 378 (1998)).

190. See, e.g., Cleveland, supra note 69; Harold Hongju Koh, International Law as Part of Our Law, 98 AM. J. INT'L L. 43, 43-45 (2004); Jackson, supra note 69, at 110 ('[R]eferences to foreign and international sources occur episodically in constitutional decisions throughout the [Supreme] Court's history."); Gerald L. Neuman, The Uses of International Law in Constitutional Interpretation, 98 AM. J. INT'L L. 82, 83-84 (2004)

191. See, e.g., Vicki C. Jackson, Constitutional Dialogue and Human Dignity: States and Transnational Constitutional Discourse, 65 MONT. L. REV. 15, $21-27$ (2004) (describing the influence of Universal Declaration of Human Rights on the text of the Montana Constitution).

192. See, e.g., Martha F. Davis, The Spirit of Our Times: State Constitutions and International Human Rights, 30 N.Y.U. REV. L. \& SOC. CHANGE 359 (2006).

193. See congressional resolutions cited supra note 68 .

194. See generally Jackson, supra note 69 , at 110 n.7 (noting several U.S. Supreme Court opinions between 1949 and 1970 that refer to the Universal Declaration of Human Rights). 
government officials to respond to identified problems within a human rights framework. ${ }^{195}$ They have done so by working not only to attain strong issuespecific conclusions and recommendations from treaty bodies, but, most importantly, to then ensure that those conclusions and recommendations are effectively addressed through participatory processes at federal, state, and local levels. ${ }^{196}$ At the same time, "shadow report" procedures that accompany periodic reporting processes ${ }^{197}$ are now regularly used by incorporationists as a teaching and awareness-raising tactic, employed as a means to train local communities on how to use human rights methodologies and understandings to address problems of local concern and to frame dialogues with governmental entities. The grassroots analyses produced from shadow reporting exercises are then used not only for formal reporting purposes in Geneva, ${ }^{198}$ but, most importantly, for pressing local, state, and federal officials for meaningful, socially relevant reforms in domestic communities.

Finally, the continued success of federal veto politics in blocking certain treaties, like the CEDAW and CRC, which raise sensitive issues for socially conservative minorities has not stopped domestic advocates from using international treaty body supervision to engage those very same issues, albeit under other treaties. Pressed by civil society advocates, the U.N. Human Rights Committee, Torture Committee, and Racial Discrimination Committee thus regularly question U.S. representatives-who provide detailed responses - on the measures the United States has taken to give legal effect to rights related to women's reproductive health and safety, gender violence, children's rights abuses, indigenous land rights, and discrimination in housing, education, healthcare, and employment, as well as to the disparate impacts of a wide variety of U.S. policies on race, ethnicity, age, sex, religious, and sexual orientation grounds.

There are in fact virtually no substantive issues arising under the CEDAW, CRC, and ICESCR that cannot in some way be addressed under the ICCPR, CERD, and CAT supervisory procedures. The same is true of the contentious individual complaints procedure supervised by the Inter-American Commission on Human Rights, which allows complaints to be lodged against the United States with respect to the full spectrum of internationally recognized rights. Incorporationist strategies have thus altered in fundamental ways the incentive structure that has historically justified mobilizing veto players to block certain treaties. Today, that incentive structure has largely

195. See supra Part III.

196. Id.

197. "Shadow reports" are parallel reports to the official treaty body reports prepared by the U.S. government. They aim to highlight and correct misstatements or generalizations in official U.S. reports, fill in overlooked areas with accurate facts, details, and statistics, and generally present an alternative view for the expert U.N. committee to consider in assessing U.S. progress and setbacks in human rights enjoyment under the supervised treaty and in making recommendations for improvements.

198. The U.S. Human Rights Network has played an important role in coordinating the large numbers of domestic advocates who travel to Geneva to participate in the supervisory process, both by consolidating issue-specific and local shadow reports into a single accessible U.S. NGO report, in coordinating advocates in making timely, effective statements to the U.N. committees, and in presenting appropriate information that is easily accessible to committee experts as they question U.S. representatives. 
been reversed: given U.S. commitments under the ICCPR, CERD, CAT, ILO treaties, and the American Declaration, there is little functional reason to oppose - and growing functional reasons to support - U.S. ratification of the CEDAW, CRC, ICESCR, and the American Convention.

\section{Responding to Incorporation's Advances: Reappropriating Rights}

The above-described reality has fundamentally changed the political environment in which traditional opponents of treaty ratification pursue their own domestic policy agendas, complicating their efforts to cordon off the domestic legal system from international interpretations that might differ from their preferred views. Many appear to be realizing that old strategies focused on ratification blocking alone are insufficient and that a failure to reassess their strategies may mean missing out on critical agenda-advancing opportunities. Consequently, interest groups have appeared increasingly to focus critical energies on ensuring that new international agreements reflect their interests and agendas at the drafting stage.

The most notable of these shifts involves the increasingly active participation of traditionally insulationist NGOs in international human rights fora. Many such groups now have a regular and active lobby at U.N. meetings and conferences, especially those related to women, children, health, and family structure. A strong, but single example has been the drafting negotiations behind the new U.N. Convention on the Rights of Persons with Disabilities, in which the U.S.-based "pro-life" movement maintained a highly visible presence and sustained political lobby over the four-and-a-half years of the treaty's negotiation. It did so with the core aim of reshaping the international meaning of rights-based terms related to reproduction, family, child-rearing, and "life," using political affinities within the Bush administration to compel the U.S. government to pursue the movement's agenda in the negotiation process.

In fact, although the United States announced at the start of the treatydrafting process in 2003 that it did not intend to participate actively in the negotiating process, ${ }^{199}$ under sustained pressure from socially conservative activist groups it changed course at the penultimate session in early 2006 . The United States announced as the reason for its reentry its strong interest in shaping the terms of the new human rights treaty-principally out of its longterm interest in ensuring the strength and consistency of international law as a general matter, but also, specifically, to avoid the inclusion of any language that might be substantively objectionable to the United States. ${ }^{200}$ The actual textual amendments proposed by the U.S. delegation, however, spoke more forthrightly to its immediate motivations. These included: strengthened

199. See Boyd Statement, supra note 40 .

200. This official change of policy was declared and explained by the U.S. delegation in public information side meetings at the seventh session of the Ad Hoc Committee charged with negotiating the treaty text. This author served as U.N. representative of a U.S.-based disability organization in the treaty drafting process. 
language on the role of the family in dependent caregiving; the deletion of references to "health services," a term understood by anti-abortion groups as an international code-word for abortion services; and the insertion of "and worth" after each treaty reference to "inherent dignity," a proposal advanced by the Vatican to bring the human fetus within the protective scope of human rights law. It also included the addition of a new draft article-the first of its kind in international human rights law-guaranteeing a right not to be denied food or fluids when dependent on life support, a thinly disguised attempt to internationalize the Terri Schiavo case in human rights terms. ${ }^{201}$ While the United States failed to achieve sufficient support for removal of "health services," it did succeed in getting substantial textual revisions to the health and family provisions, the addition of "and worth," and inclusion of the essence of its food and hydration provision. ${ }^{202}$

On the basis of these successes, the conservative NGO movement has intimated support for U.S. ratification of the Disability Convention. At a minimum, it has signaled that the time for wholesale rejection of international human rights law has passed. In speaking of the new Disability Convention, a conservative commentator recently wrote in the Weekly Standard:

Can anything good come out of the United Nations? Actually, yes. . . The positive impact [of conservative NGO participation in the Disability Convention drafting negotiations] teaches a valuable lesson. Many conservative organizations eschew obtaining NGO status with the United Nations because they loathe internationalism, disdain the U.N., and expect America not to be bound by these agreements.

But such standoffishness is woefully shortsighted. Like it or not, many of the most important social and legal policies of the twenty-first century are going to be materially influenced by international protocols such as this one. These agreements are molded substantially behind the scenes by NGOs-most of which are currently leftist in their political outlooks and relativistic in their social orientation. This makes for a stacked deck. If conservatives hope to influence the moral values of the future, they are going to have to hold their collective noses and get into the game. ${ }^{203}$

We should increasingly expect to see this: a more active engagement by traditionally insulationist NGOs in the construction of normative meaning at the international level-accompanied by more vigorous pressure on sympathetic U.S. officials to engage human rights organs in pursuit of this norm-reappropriation agenda. ${ }^{204}$

201. This author monitored all U.N. member state proposals as they were made. While the U.S. drafting proposals had partisan undertones, the United States played a positive role overall in mediating diverse international interests within the negotiations. Its renewed participation in the drafting process in 2006 was welcomed by all govermments and civil society actors.

202. The much longer and detailed draft provision was, in a final compromise deal, significantly condensed and consolidated into a subprovision of the right-to-health article, which reads: "States Parties shall: ... Prevent discriminatory denial of health care or health services or food and fluids on the basis of disability." Disability Convention, supra note 40, ant. 25.

203. Wesley J. Smith, $A$ Worthwhile U.N. Initiative! $A$ Welcome Defense of the Disabled from an Unlikely Organization, WKLY. STANDARD, Jan. 29, 2007, at 15-16 (emphasis added).

204. As an example of U.S. officials carrying out socially conservative social movement agendas abroad, two Republican members of the U.S. House of Representatives went so far as to send a letter to the Special Rapporteur on the Rights of Women of the Inter-American Commission on Human Rights in early 2007, in anticipation of the Rapporteur's scheduled trip to Nicaragua to meet with women's groups and the government. In it, the Special Rapporteur was instructed not to discuss a legislative bill then before the Nicaraguan Congress that proposed adding life and health exceptions to 
V. MEDIATING TECHNIQUES FOR PROMOTING U.S. ENGAgEMENT: ASSERTING CLEAR JURISDICTIONAL LINES AND RECURRING (SELECTIVELY) TO SUBSIDIARITY DOCTRINE

What do these instrumental realignments mean for the United States and its future engagement with human rights treaty bodies? The U.S. position is often presented, inaccurately and unhelpfully, as monolithically opposed to human rights treaty body engagement. In fact, it is most useful to view U.S. human rights policy in fluid and responsive terms: as a careful mediation between distinct political pressures-from realist and institutionalist tendencies at the foreign policy level, liberal and conservative and/or incorporationist and insulationist persuasions at the domestic policy level, and "political process" versus "legal process" preferences more generally. The United States, in its policy positions, mediates these pressures, bowing more or less to one or the other at distinct political conjunctures and with shifting electoral politics. Yet, importantly, as its engagement practice reveals, it does so always within the parameters of a clearly articulated and jurisdictionally focused set of legal principles that frame and anchor the U.S. policy position.

These principles, drawn from the lettered texts and doctrines of international law, serve as essential mediating tools in the articulation of U.S. human rights policy. Indeed, as presently invoked, they appear to be advanced with a distinct policy aim: to set bright-line rules with respect to the scope of treaty body competence in precisely those areas that make conservative critics, at both domestic and foreign policy levels, most politically exercised. The resulting U.S. posture at once accommodates those concerns, particularly as articulated through federalism, sovereignty, and national security objections - the priority concerns of domestic policy insulationists and foreign policy realists-while opening a viable political space in which active U.S. engagement with human rights treaty bodies may feasibly be pursued.

Significantly, the United States justifies this policy response not through resort to any exceptionalist notion of its power or political culture, but rather through formal, repeated, and insistent resort to two of international law's most foundational building blocks: the doctrine of sovereignty and the principle of subsidiarity.

Both doctrines provide a sturdy foundation for constructively advancing U.S. human rights policy toward the future. Their strategic use as a mediating device in U.S. engagement policy nonetheless comes clearly into focus upon considering that the United States currently invokes them before treaty bodies exclusively in their negative components: as doctrines of noninterference and deference to domestic political processes. Largely absent from the discourse is a parallel focus on their more positive aspects of assistance and support in strengthening domestic processes of human rights enforcement.

Because this selective use is so important for understanding both the mediated nature of U.S. engagement and the possibilities for using U.S. reliance on international legal doctrines as a foundation for building a more 
robust domestic human rights agenda, the following two sections discuss the primary set of sovereignty and subsidiarity-based mediating techniques that presently define U.S. engagement policy. These techniques fall into three distinct categories: (1) a bright-line, doctrinal statement of the substantive and spatial boundaries of treaty body jurisdiction, with a view to preserving the flexibility of foreign policy responsiveness in times of war or threats to global public order; (2) a close attention to the technical-jurisdictional boundaries of "contentious" dispute mechanisms versus "promotional" ones, narrowing access to the former and preferring reliance on the latter; and (3) an aggressive insistence on the nonbinding nature of all international treaty body decisions and conclusions, aimed at underscoring the primacy of domestic political process.

These three positions are advanced in virtually all international treaty body engagements, frequently as a direct preface to legal briefs and oral arguments. The first draws heavily on the negative dimensions of the sovereignty doctrine, the latter two on the negative dimensions of subsidiarity. While domestic advocates often view these three positions as a manifestation of the United States's stubborn refusal to accede to the binding rules of international law, they are, in many respects, just the opposite: a mediating posture that relies on the formal rules of international law to allow the United States to engage with supervisory human rights bodies on the widest diversity of subject matters feasible at a given political conjuncture.

\section{A. Sovereignty-Based Mediating Techniques: Carving Out "No Go" Zones in Treaty Body Competence}

The first international law doctrine tactically recurred to in U.S. engagement policy is that of state sovereignty. For over 350 years, since the Peace of Westphalia, the sovereignty doctrine has functioned to divide spheres of internal control among sovereign states, recognizing a sovereign's right to possess full and effective control over its internal affairs, as a means of promoting and preserving global public order. ${ }^{205}$ Within this context, sovereignty has both a positive and a negative dimension.

The positive dimension of sovereignty is reflected in the duty of nationstates to protect the rights of individuals within their own territorial jurisdictions and to respect the right of other nations to protect their own. ${ }^{206} \mathrm{It}$ requires not only restraint in interfering in the affairs of other states, but also encompasses affirmative obligations to take appropriate measures within a nation's own jurisdiction to protect the rights of foreign nationals and, 
consistent with the doctrine of "popular sovereignty," to abide by the democratically expressed policy choices of its peoples. ${ }^{207}$

It is the corresponding negative dimension of the sovereignty doctrine, however, that is most frequently invoked by U.N. member states, including the United States. This dimension serves as a consent-based doctrine of noninterference in the internal affairs of a nation: international actors may not interfere in a nation's domestic matters beyond the self-defined limits of a nation's affirmative, freely given and unambiguous consent. ${ }^{208}$ It is primarily this negative aspect of the sovereignty doctrine that the United States recurs to in its treaty body engagements. Specifically, U.S. policy spotlights the absence of U.S. consent to international supervision in certain defined spheres, and hence the limits of treaty body jurisdiction over U.S. conduct in those carefully circumscribed areas (what I call "no go" zones).

This doctrinally based sovereignty posture serves a number of instrumental ends. Most importantly, it allows the United States to effectively manage countervailing policy interests between realists and institutionalists at the foreign policy level. ${ }^{209}$ As discussed, while institutionalists push for greater treaty body engagement generally, given the correlative benefits it confers for achieving broader U.S. foreign policy interests, realists pull away from it in precisely those areas where engagement may serve as a constraint on U.S. prerogative to respond by all means necessary to foreign threats, particularly in times of war and armed conflict. The United States responds to these conflicting foreign policy pressures, drawing on the negative dimensions of the sovereignty doctrine, by supporting a policy of "full" jurisdictional engagement with international human rights treaty bodies within their ratione materiae and ratione loci competence. The United States then defines these jurisdictional parameters, using positivist international law doctrines, as exclusive of alleged abuses arising in two discrete circumstances: in situations of armed conflict and in extraterritorial loci, both areas where foreign policy sensitivities have been strongest. It resorts to the full set of internationally accepted methods of treaty interpretation, consistent with the Vienna Convention on the Law of Treaties, to support this jurisdictional interpretation. ${ }^{210}$

While this posture has become the focal point of scholarly and advocacy critique of U.S. human rights policy since 2001-given official removals of

207. W. Michael Reisman, Sovereignty and Human Rights in Contemporary International Law, 84 AM. J. INT'L L. 866, 869 (1990); see also id. at 872 (noting that 'the word 'sovereignty' can no longer be used to shield the actual suppression of popular sovereignty from external rebuke and remedy" and international law's modern emphasis on protecting "the continuing capacity of a population freely to express and effect choices about the identities and policies of its governors").

208. The definitiveness of consent in international law, with the narrow exception of areas governed by international customary law, is established in the Vienna Convention on the Law of Treaties, supra note 38, pmbl., art. 2(1).

209. Murphy refers to a similar tension as the antinomy of exceptionalism versus sovereign equality. Murphy, supra note 12.

210. See, e.g., Third Periodic Report, supra note 86, Annex 1, at 109-11 (relying on ordinary meaning, travaux préparatoires, U.S. practice, context at conclusion, and views of eminent public jurists, identified expressly as proper means of interpretation under the Vienna Convention on the Law of Treaties). 
rights-abusive conduct to extraterritorial loci and other "war on terror" abuses ${ }^{211}$-it is useful to take a step back and view the U.S. position in larger perspective, outside of abusive applications, for what it represents at its core: a mediation tactic. Faced with powerful pressures to disengage entirely with international supervisory bodies, should competence be exercised over U.S. military interventions or "war on terror" subjects-as the United States has done with other international tribunals, such as the $\mathrm{ICC}^{212}$ or $\mathrm{ICJ}^{213}$-the U.S. decision to remain actively engaged in human rights treaty procedures while carving out limited subject-matter "no go" zones may be viewed, more positively, as a compromise strategy to conserve U.S. human rights engagement in all other areas of domestic human rights abuse. This is an enormous field, and U.S. willingness to engage with it should not be minimized. ${ }^{214}$

It is important to note, moreover, that the United States's position in this regard is not new. It represents a long-term policy on the part of the U.S. government, regularly raised in international fora wherever U.S. conduct in situations of war, war-related recovery, or conflict abroad has been challenged. ${ }^{215}$ Initially advanced in the 1950 s as a pragmatic concern in the ICCPR drafting process with respect to the U.S.-led post-World War II recovery process in Europe and Japan, ${ }^{216}$ this longstanding position in many ways today reflects U.S. self-awareness as the world's sole remaining military superpower in a world in which international law constitutes "an effective but limited . . . structure. ${ }^{, 217}$ In consequence of that awareness, and consistent with realist pressures, the United States has persistently rejected jurisdictional

211. See supra note 160. But cf. Exec. Order No. 13,491, 74 Fed. Reg. 4893 (Jan. 22, 2009) (revoking torture authorizations and closing Central Intelligence Agency detention facilities).

212. In May 2002, President George W. Bush renounced the United States's prior signature of the Rome Statute of the International Criminal Court, asserting in a letter to the U.N. Secretary-General that "the United States has no legal obligations arising from its signature on December 31, 2000." Letter from John R. Bolton, U.S. Under Sec'y of State for Arms Control and Int'l Security, to Kofi Annan, U.N. Sec'y-Gen. (May 6, 2002), available at http://2001-2009.state.gov/r/pa/prs/ps/2002/ 9968.htm; see also Swaine, supra note 38.

213. The United States withdrew from the ICJ's compulsory jurisdiction in 1986, following the Court's adverse decision against it in Military and Paramilitary Activities in and Against Nicaragua (Nicar. v. U.S.), 1986 I.C.J. 14 (June 27). On March 7, 2005, following another merits loss, it terminated the Court's treaty-specific jurisdiction over it with respect to alleged breaches of the Vienna Convention on Consular Relations. See Journal of the United Nations, No. 2005/48, at 13 (Mar. 12, 2005) (reporting the U.N. Secretary-General's receipt of U.S. withdrawal notification to Convention's Optional Protocol).

214. It covers areas such as discrimination, political participation, due process, health, housing, prison conditions, education, labor rights, and access to justice. The U.S. opening to international supervision with respect to these domestic areas represents a critical advance. This, of course, is not to say that advocates should not continue to challenge the legitimacy of "no go" zones, particularly unjustifiable uses of them to commit human rights abuse. It is only to say that U.S. human rights policy should not be judged exclusively on the basis of "no go" zones.

215. See, e.g., Coard v. United States, Case 10.951, Inter-Am. C.H.R., Report No. 109/99, OEA/Ser.L/V/II.106, doc. 6 rev., fT 38, 41 (1999).

216. The resulting language in Article 2 of the ICCPR ("within its territory and subject to its jurisdiction") remains at the center of the U.S. policy position on the extraterritorial scope of human rights treaty obligations. See Third Periodic Report, supra note 86, at 109-11 (emphasis added).

217. W. Michael Reisman, Unilateral Action and the Transformations of the World Constitutive Process: The Special Problem of Humanitarian Intervention, 11 EUR. J. INT'L L. 3, 9 (2000). 
recognition of treaty body authority in situations of extraterritorial and armed conflict. This posture enables it to maintain maximum flexibility to respond to threats to national security and global public order-including the leeway to engage in what has been termed "operational noncompliance" 218 - without having to justify its conduct before international expert bodies through resort to legitimate or permissible restrictions on rights, such as those required to protect the rights and security of others. ${ }^{219}$

Significantly, in rejecting treaty body supervision in these limited areas, the United States does not claim immunity from the binding rules of international human rights and humanitarian law, nor that human rights or humanitarian abuses do not occur within "no go" zones. Rather, its argument is a narrow jurisdictional one: treaty bodies, as a technical matter, lack jurisdiction over the United States in such areas, given the United States's historically based and persistently expressed position on the scope of its treaty undertakings. ${ }^{220}$ Under this view, human rights complaints in this sensitive foreign policy and rights-balancing area are valid, but best reserved to political mechanisms of control: media attention, political pressure, congressional oversight and investigation mechanisms, international censure, and diplomatic pressure. These controls are seen as best capable of advancing the shared community goal of global human rights protection-both in most effectively restoring fundamental rights protections as soon as any national or global threat diminishes ${ }^{221}$ and by removing a structured disincentive to

218. Jacob Katz Cogan, Noncompliance and the International Rule of Law, 31 YALE J. INT'L L. $189,191(2006)$ (" $[N]$ oncompliance that keeps a partially effective system, such as international law, operational by reconciling formal legal prescriptions with changing community policies or by bridging the enforcement gap created by inadequate community mechanisms of control." (citation omitted)).

219. Human rights law is in fact designed to allow for this sort of practical accommodation, expressly allowing for justified restrictions on the enjoyment of rights, both in the general interest and, specifically, in times of national emergency. Human rights bodies consistently, moreover-whether explicitly or implicitly-provide a higher margin of discretion to states in crafting such justified restrictions in national security situations. See, e.g., Ireland v. United Kingdom, 2 Eur. H.R. Rep. 25, 9495 (1978); "Lawless" Case, 2 Eur. Ct. H.R. (ser. A) at 23 (1961); "Lawless" Case, 3 Eur. Ct. H.R. (ser. A) at 27 (1961). The U.N. Special Rapporteur on Extrajudicial, Summary, or Arbitrary Executions, Philip Alston, has accordingly urged the United States to adopt this human rights-based approach: rather than argue that human rights law does not apply in situations of armed conflict and thereby resist supervision, the United States might more usefully argue that its actions represent "justified" conduct in times of war or armed conflict within the frame of human rights law. Press Release, Office of the High Comm'r for Human Rights, Special Rapporteur on Extrajudicial, Summary, or Arbitrary Executions, U.N. Doc. HR/07/51 (Mar. 28, 2007); see also Special Rapporteur on Extrajudicial, Summary, or Arbitrary Executions, Implementation of General Assembly Resolution 60/25I of 15 March 2006 Entitled "Human Rights Council", U.N. Doc. A/HRC/4/20 (Mar. 12, 2007). The United States has decided that it prefers not to take this course, at least not at present or as an exclusive option.

220. See Press Release, U.S. Mission to the U.N. in Geneva, Statement on Behalf of the U.S. Delegation to the U.N. Human Rights Committee (July 28, 2006), available at http://www.usmission.ch/Press2006/0728ICCPR.html ("We can understand the Committee's desire to have the Convention apply outside the territory of a State Party but we must accept the Convention the way it was written, not the way the Committee wishes it to be. Despite this clear limitation of its mandate, the Committee has made at least six separate recommendations that concern U.S. activities outside the territorial United States that are governed by the laws of war. We find these conclusions outside the scope of the Committee's mandate an unfortunate diversion of the Committee's attention." (emphasis added)).

221. For a supportive view of this approach in the domestic context in times of war, see William H. ReHNQUiST, All the LaWS BUT ONE: Civil RIGHTS IN WARTIME (1998), which discusses suspension of habeas corpus and other civil rights protections in times of war. 
responsive unilateral action in situations of humanitarian crisis or other threats to global public order to which the international community cannot or will not respond.

This is, however, the only area in which the United States should be expected to refuse supervision in its engagement policy. It is a bow to the power of foreign policy realists, enabling the United States to continue its otherwise substantively plenary engagement policy and thereby attend to other domestic and foreign policy pressures and agendas.

\section{B. Subsidiarity-Based Mediating Techniques: Emphasizing Doctrines of Deference to Domestic Political Process}

The United States likewise draws heavily, if selectively, on international human rights law's principle of subsidiarity in its treaty body engagement. This practice is directed not to balancing competing foreign policy agendas, but rather to maximally accommodating the conflicting agendas of foreign policy institutionalists and domestic policy insulationists. That is, the United States must reconcile the powerful push of institutionalists for more robust engagement with human rights treaty regimes and norms, with the equally powerful pull-back of domestic policy insulationists, who seek to insulate domestic decisionmaking processes from the influence of the same regimes and norms. To manage these countervailing pressures, the United States resorts to an important set of mediating techniques drawn from the substantive rules, procedural devices, and deference doctrines developed in international law to give effect to the subsidiarity principle.

The principle of subsidiarity is foundational to both the protective function of modern international human rights law and the institutional identity of human rights supervisory bodies. ${ }^{222}$ Triggered once a sovereign state undertakes supervised international human rights commitments, it operates as an essential flexibility device in governing the appropriate relationship between international, national, and subnational supervision in the shared project of protecting the human rights of all individuals within a state's jurisdiction.

222. That international systems of human rights protection are inherently subsidiary to domestic systems has long been recognized by, for example, the European Court of Human Rights, the Inter-American Court on Human Rights, and the Inter-American Commission of Human Rights. See, e.g., Z. v. United Kingdom, 200I-V Eur. Ct. H.R. I; Akdivar v. Turkey, 1996-IV Eur. Ct. H.R. 1192, para. 65; Eckle v. Germany, 1982 Eur. Ct. H.R. (ser. A) at 51, para. 61; Handyside v. United Kingdom, 1976 Eur. Ct. H.R. (ser. A) at 24, para. 28; Cesti Hurtado Case, 1999 Inter-Am. Ct. H.R. (ser. C) No. 44, If 47 (Jan. 26, 1999); Abella v. Argentina, Case 11.137, Inter-Am. C.H.R., Report No. 55/97, OEA/Ser.L/V/II.98, doc. 7 rev., ff 139-40 (1997); Bermúdez v. Honduras, Case 11.206, Inter-Am. C.H.R., Report No. 46/96, OEA/Ser.L/V/II.95, doc. 7 rev., If 31-32 (1996); Marzioni v. Argentina, Case 11.673, Inter-Am. C.H.R., Report No. 39/96, OEA/Ser.L/V/II.95, doc. 7 rev., Rf 48-49 (1996). This subsidiarity relationship is underscored in the Preamble to the American Convention on Human Rights, which justifies the Convention's international protection as "reinforcing or complementing the protection provided by the domestic law of the American states." The principle of subsidiarity was formally enshrined in the Charter of Fundamental Rights of the European Union in December 2000. Charter of Fundamental Rights of the European Union, Dec. 7, 2000, 2000 O.J. (C 364) 1, pmbl. \& art. 51 , reprinted in 40 I.L.M. 266 (2001). 
As such, the principle of subsidiarity has both a negative and a positive dimension. Designed to ensure the maximum flourishing of the human individual in his or her social context, ${ }^{223}$ these dual dimensions are reflected in the complementary duties of noninterference and assistance (or subsidium), each owed by all social actors and institutions to each other, at the local, national and international levels. ${ }^{224}$

The first of these duties, the duty of noninterference, requires that larger, more comprehensive organizations do not interfere in the freedom of smaller organizations to meet their own human dignity needs in ways that authentically accord with their own realities, prerogatives, and beliefs. "It requires that problems be solved where they occur, by those who understand them best, and by those who are most affected by them.,"225 This follows not only from the fact that local needs are best appreciated by local actors, but also from the fact that, in a world characterized by pluralism and difference, the value of human dignity can be instantiated in a diversity of ways, each of which may fully accord with the broad purposes to which human rights aim. As such, a respectful degree of latitude and deference must be given to smaller organizations to interpret and implement human rights free from external interference or control.

Yet, just as the subsidiarity principle does not tolerate preemption of smaller social or political units, neither does it support wholesale devolution

223. The principle of subsidiarity that underlies human rights law should not, in this way, be confused with the narrower, more rigid rule of the same name that has developed since 1993 in the European Union to govern the constitutional relationship between the Union and its member states. That rule, more akin to U.S. federalism, serves to divide legislative competences between overlapping sovereigns, establishing when EU member states must conform their laws to EU rules and directives. See Treaty of Amsterdam Amending the Treaty on European Union, the Treaties Establishing the European Communities and Certain Related Acts arts. 1, 2, 5, Oct. 2, 1997, 1997 O.J. (C 340) 1; see also Carozza, supra note 15, at 52 ("[I]t would truly impoverish our discourse . . . to limit subsidiarity to a technical European rule that does not grow up out of that ground.").

The similarities between EU subsidiarity and U.S. constitutional federalism have spawned a vast comparative literature. See, e.g., George A. Bermann, Taking Subsidiarity Seriously: Federalism in the European Community and the United States, 94 Colum. L. Rev. 331 (1994); Cary Coglianese \& Kalypso Nicolaïdis, Securing Subsidiarity: The Institutional Design of Federalism in the United States and Europe, in THE FEDERAL VISION: LegITIMACY AND LEVELS OF GOVERNANCE IN THE UNITED STATES AND THE EUROPEAN UNION 277 (Kalypso Nicolaïdis \& Robert Howse eds., 2001); Gerald L. Neuman, Subsidiarity, Harmonization, and Their Values: Convergence and Divergence in Europe and the United States, 2 ColuM J. EUR. L. 573 (1996); W. Gary Vause, The Subsidiarity Principle in European Union Law-American Federalism Compared, 27 CASE W. RES. J. INT'L L. 61 (1995).

224. Subsidiarity represents in this way the constitutive scaffolding around what may usefully be visualized as a series of nested circles, with the individual human person sitting at the center, surrounded concentrically by progressively larger social groupings of family, civic solidarity associations, local government, nation-state, and, ultimately, intergovernmental bodies and transnational social networks.

225. J.E. Linnan, Subsidiarity, Collegiality, Catholic Diversity, and Their Relevance to Apostolic Visitations, 49 JURIST 399, 403 (1989). The passage continues: "only when their efforts fail should the matter be placed before a higher authority." Id. Carozza provides the long history to the concept of subsidiarity, tracing its intellectual history from classical Greece, through medieval scholasticism, seventeenth-century secularist theory, the work of eighteenth-century titans like Montesquieu, Locke, and Tocqueville, nineteenth-century Catholic social theory, until finally transposed from social philosophy into positive law by Germany in its post-World War II drive to undo the massive centralization of national socialism and to devolve power to the Länder. See Carozza, supra note 15. 
to them. ${ }^{226}$ Accordingly, whenever smaller social or political groupings cannot ensure the protection of human dignity without assistance, larger groupings have a "positive" responsibility to intervene-e.g., by "directing, watching, urging, restraining, as occasion requires and necessity demands" 227 - to assist them in fulfilling the objectives of the common good. The role of the subsidiarity principle, then, is to act as a flexible mediator, policing the boundary between "noninterference" and "assistance" to maximize the space in which effective protection for human dignity can be ensured at levels closest to affected individuals.

U.S. engagement policy nonetheless tends to invoke the formalized tools of only the negative half of subsidiarity's project: the "noninterference" principle. This partial emphasis, designed to reap the foreign policy benefits of engagement while attending to insulationist democracy-based objections to it, can be seen in four specific mediating tactics characteristically employed in U.S. engagement practice. It bears emphasis that while insulationist objections to human rights regimes tend to be framed in terms of U.S. sovereignty, the United States responds at the international level by insisting on the negative dimensions of subsidiarity. ${ }^{228}$ The procedural devices and doctrines it calls upon to do so fall into two distinct mediating categories, each considered below.

\section{Preferring "Political" to "Judicial" Controls in Human Rights Supervision and Interpretation}

The first set of subsidiarity-based mediating techniques employed by the United States serve to accommodate the tension between engagement as a foreign policy objective and domestic-level resistance to that engagement by those who view it as a threat to constitutional democracy. Such domestic resistance, often rooted in simple partisan political preferences, generally manifests itself in two classic arguments. The first involves traditional federalism and states' rights claims. ${ }^{229}$ The second departs from the perceived "undemocratic" nature of treaty bodies, in the sense that their members are not elected by nor directly accountable to U.S. citizens and relatedly are called upon to interpret treaties that reflect global majoritarian mores, not necessarily

226. See, e.g., Robert K. Vischer, Subsidiarity as a Principle of Governance: Beyond Devolution, 35 IND. L. REV. 103 (2001) (arguing that the "compassionate conservatism" platform of the Republican party purports to enact the lessons of Catholic teachings on subsidiarity, but in so doing advocates wholesale devolution to local authorities, neglecting subsidiarity's core focus on assistance from higher authorities).

227. Carozza, supra note 15, at 42 (quoting Pope Pius XI, Quadragesimo Anno (1931), reprinted in 3 THE PAPAL ENCYCLICALS, 1903-1939, at 415 (Claudia Carlen ed., 1981)).

228. There is, in this sense, a close and important affinity between the positive dimensions of sovereignty and the negative dimensions of subsidiarity.

229. See, e.g., Curtis A. Bradley, The Treaty Power and American Federalism, 97 MicH. L. REV. 390, 461 (1998) (asserting that treaty power is inconsistent with the principle that the national government's powers are limited and enumerated and that states have rights to legislate independently in certain spheres, concluding that government must therefore "make a choice": human rights treaties or American federalism). 
U.S. ones. ${ }^{230}$ This countermajoritarian critique, paralleling similar critiques at the domestic level with respect to the role of the U.S. judiciary in interpreting broadly worded constitutional rights, is amplified where international tribunals are concerned, particularly given rhetorical assertions that they will compel the United States to adopt foreign rights constructions that conflict with democratically determined domestic understandings in sensitive, politically contested areas. This follows not only from the fact that treatybased human rights norms tend to be drafted at a high level of generality, open to widely diverse interpretations by different social and cultural mediators, ${ }^{231}$ but also from common objections that international "experts" or "judges" have no necessary connection to the United States and are elected principally by foreign sovereigns that may have interests or agendas averse, or even hostile, to those of the United States.

Significantly, both the "states' rights" and "democratic deficit" objections are voiced most vehemently in one area of particular insulationist concern: the possibility of direct judicial enforcement of human rights treaty law. ${ }^{232}$ Insulationists object to such enforcement both by U.S. federal courts ${ }^{233}$ and by supranational human rights treaty bodies exercising adjudicatory or quasi-adjudicatory powers.

The United States answers these objections through the regular use of three specific procedural devices drawn from the principle of subsidiarity, each designed to preserve the primacy of political control mechanisms. They operate by limiting the jurisdictional competence of judicial or quasiadjudicatory bodies over raw human rights complaints - those unmediated by domestic political processes.

The first involves the regular attachment of non-self-execution declarations to human rights treaties upon ratification. ${ }^{234}$ Widely employed by democracies around the world to ensure democratic deliberation around the meaning of broadly worded treaty norms, ${ }^{235}$ such declarations assert that

230. See, e.g., Roger P. Alford, Misusing Sources To Interpret the Constitution, 98 AM. J. INT'L L. 57, 59 (2004) (discussing his view of "international countermajoritarian difficulty"); Curtis A. Bradley, International Delegations, the Structural Constitution, and Non-Self-Execution, 55 STAN. L. REv. 1557, 1558 (2003) ("By transferring legal authority from U.S. actors to international actorsactors that are physically and culturally more distant from, and not directly responsible to, the U.S. electorate-these delegations may entail a dilution of domestic political accountability."); $c f$. John $\mathbf{O}$. McGinnis \& Ilya Somin, Should International Law Be Part of Our Law?, 59 STAN. L. REV. 1175, 1177 (2007) (limiting their critique to "raw international law," i.e., that which has not been endorsed by the domestic political process).

231. See, e.g., Goldsmith, supra note 178, at 338-39 ("In and among pluralistic democratic societies, there is a reasonable scope for disagreement about what broadly worded human rights norms require. When the human rights community demands that the United States make international human rights treaties a part of domestic law in a way that circumvents political control, it evinces an intolerance for a pluralism of values and conditions, and a disrespect for local democratic processes.").

232. See supra note 178 and accompanying text.

233. Goldsmith, supra note 178 , at 332 ("Domestic incorporation of the ICCPR . . . would constitute a massive, largely standardless delegation to federal courts to rethink the content and scope of nearly every aspect of domestic human rights law.").

234. See supra text accompanying notes 176-177.

235. Many democratic nations, including Australia, Canada, India, Mexico, and the United Kingdom, likewise recognize the non-self-execution doctrine. See, e.g., R.J. MacDonald, The Relationship Between International Law and Domestic Law in Canada, in CANADIAN PERSPECTIVES ON 
ratified treaty norms do not create private causes of action for direct enforcement by the domestic judiciary. ${ }^{236}$ Rather, to be judicially cognizable, they must first be given locally relevant content in domestically enforceable implementing legislation. This tactic bows directly to institutionalists and indirectly to incorporationists, but, in a concession to insulationists, insists that any incorporation be done by domestic legislatures or other political processes, not courts.

The second subsidiarity-based mediating tactic extends the same principle upward, from the domestic judiciary to the international treaty body system. It takes advantage of the fact that international treaty law generally makes judicial or quasi-judicial complaints mechanisms optional for states parties. ${ }^{237}$ In an effort to mediate competing institutionalist and insulationist pressures, the United States thus affirmatively accepts the jurisdiction of human rights treaty bodies for purposes of active and regular engagement, but only with respect to nonadjudicatory functions. Where given a choice, the United States reliably submits only to periodic reporting and other promotional functions that focus on "constructive dialogue" with international supervisory bodies, not rights "adjudication.," ${ }^{238}$ U.S. compliance with treaty obligations can thereby be discussed and debated in general ways, without an international adjudication that a specific policy or practice has violated the rights of distinct individuals and hence requires a specific remedial response, independent of domestic appreciation of the matter.

Finally, a third set of subsidiarity-based procedural devices is used in the few instances in which the United States is in fact mandatorily subject to international adjudicatory or case-based claims processes as a requirement of membership in a given intergovernmental organization. ${ }^{239}$ In such circumstances, the United States relies heavily on the subsidiarity-based jurisdictional rules that limit treaty body competence over contentious cases, such as the exhaustion of domestic remedies requirement, the "fourth instance formula," and strict ratione materiae, personae, loci and temporis limitations. ${ }^{240}$ These procedural devices, recognized in all international adjudicatory fora, are designed to give effect to the principle that human rights treaty bodies should never arrogate to themselves functions that can more immediately and effectively be undertaken at more local levels. U.S. engagement practice is correspondingly characterized by an emphasis on the extensive opportunities the litigant is or was afforded to address the issue through domestic legal and political processes and the ultra vires nature of

INTERNATIONAL LAW AND ORganization 88, 120-21 (R.J. Macdonald, Gerald L. Morris \& Douglas M. Johnston eds., 1974).

236. See supra note 176.

237. See supra note 105 and accompanying text.

238. See supra Section III.B.

239. The OAS and ILO have such compulsory membership requirements. See supra note 108 and accompanying text.

240. See supra note 124 and accompanying text. 
international jurisdiction where domestic processes provide full due process of law and effective redress to the alleged victim. ${ }^{241}$

\section{Retaining Full Remedial and Policymaking Discretion}

The United States employs a fourth mediating technique likewise derived from subsidiarity's negative dimension. This technique draws not on procedural devices designed to limit the exercise of adjudicatory competence, as do the former three, but rather on a subsidiarity-based doctrine of substantive deference applicable once competence is in fact asserted. Premised on the understanding that local actors are in the best position to appreciate the complexity of circumstances on the ground and, correspondingly, to understand what measures may be most effective for internalizing human rights values in distinct contexts, that doctrine mandates that a certain margin of discretion be given to competent authorities in the determination of rights abuse and in the crafting of appropriate responsive measures to it. ${ }^{242}$ This subsidiarity-based deference doctrine is given regular effect in treaty body practice: both through the standard of review used to assess state compliance with treaty undertakings and, more broadly, through the general recognition that treaty body conclusions are recommendatory in nature, providing states ample leeway to tailor responses appropriately to local conditions and constraints.

This fourth subsidiarity-based mediation tactic is articulated in U.S. engagement practice through regular U.S. assertions that all treaty body conclusions and recommendations, although welcome and appropriately taken into broader political account, are nonbinding and have no independent domestic legal force. ${ }^{243}$ Such nonbindingness is asserted with equal degrees of force with respect to the final recommendations issued by treaty bodies under contentious individual complaints procedures and those derivative of constructive dialogue and periodic reporting. By doing so, the United States seeks to underscore its full retention of plenary discretion to adopt its policies the way it chooses, notwithstanding U.S. submission to and engagement with international supervisory procedures.

In making this assertion, the United States does not affirm anything that is new to international law: the nonbinding nature of human rights treaty body recommendations is, as a matter of international human rights law, largely uncontroversial, ${ }^{244}$ as is the ability of states parties to adopt measures of their

241. These arguments are consistently made by the U.S. delegation in contentious proceedings before the Inter-American Commission on Human Rights. The author, a specialist in the regional system, is an active observer of Commission proceedings.

242. For a discussion of this doctrine as it has developed in the European system, see HowARD Charles Yourow, The Margin of Appreciation Doctrine IN the DyNamics of European Human RIGHTS JURISPRUDENCE (1996).

243. See supra Sections III.A and III.B.

244. Quasi-judicial human rights treaty bodies are empowered to issue "recommendations" only, as distinguished from supranational courts that issue "final judgments." See, e.g., American Convention, supra note 80, art. 50.3 ("Commission may make such proposals and recommendations as it sees fit."); id. art. 67 ("The judgment of the Court shall be final and not subject to appeal."). 
sovereign choosing in giving effect to treaty obligations. ${ }^{245}$ Rather, the United States appears to use this policy to speak directly to domestic constituencies, underscoring to insulationists that mere engagement with treaty body regimes will not force the United States to adopt policies that have not been fully mediated through the democratic process. This important mediating tactic nevertheless puts increasing strain on U.S. relationships with international tribunals. It also invites charges of paradox and double standards from domestic and international observers alike, who often read U.S. assertions of the nonbindingness of the views and recommendations of treaty bodies as an assertion of the nonbindingness of the treaty commitments themselves. ${ }^{246}$ The U.S. government labors to clarify this distinction at the international level, consistently affirming its full acceptance of all treaty obligations duly undertaken. Consistent with interest management, it works less hard to make the distinction clear at the domestic level.

\section{Mediation Through Jurisdictional Aggressiveness}

Each of the aforementioned mediating techniques, whether based in the doctrinal principles of sovereignty or subsidiarity, shares a common defining feature: an insistence on the United States's unflinching fidelity to both the formal rules of international law and the jurisdictional parameters of treaty body competence. This doctrinally anchored, legal-jurisdictional approach may most profitably be understood as a mediating technique in itself.

First, and most directly, aggressive U.S emphasis on international law doctrine and jurisdiction creates a firm anchor from which insulationist minorities can be politically appeased within the formal letter of U.S. human rights treaty commitments. This allows the United States to attend to domestic oppositional pressures while simultaneously confuting charges of exceptionalism, which can be distracting to institutionalists in the foreign policy arena. On the other hand, and most consequentially from a domestic policy standpoint, by changing the relevant vocabulary of resistance, it may serve to diffuse and transcend the rhetoric that has historically given rise to rights-cultural exceptionalist demands at home. By caricaturing human rights law in absolutist terms as contrary to and in direct conflict with U.S. constitutionalism, democracy, and sovereignty, that rhetoric has served as the primary basis for mobilizing domestic resistance to human rights treaty ratification and engagement. ${ }^{247}$

245. See, e.g., Certain Attributes of the Inter-American Commission on Human Rights, Advisory Opinion OC-13/93, 1993 Inter-Am. Ct. H.R. (ser. A) No. 13, \29 (authority of Commission to find violation does not confer "authority to rule as to how a legal norm is adopted in the internal order," which "is the function of the competent organs of the State").

246. See infra note 257 and accompanying text.

247. While rarer to find in the U.S. State Department, which consistently takes a more multilateralist and international law-based approach, this "rights cultural" rhetoric continues to be used by some attorneys in the U.S. Department of Justice as a rationale for why the United States should not ratify human rights treaties. For a recent published example, see Tracey R. Justesen \& Troy R. Justesen, An Analysis of the Development and Adoption of the United Nations Convention Recognizing the Rights of Individuals with Disabilities: Why the United States Refuses To Sign This UN Convention, HuM. RTS. BRIEF, Winter 2007, at 36, 39-4l. For a counter-perspective, see Tara J. Melish, The UN Disability 
The jurisdictional aggressiveness of the U.S. human rights policy may thus most profitably be understood as a mediating strategy designed to transcend this rhetorical and absolutist view of human rights law, and to bring it back in line with the actual foundations of human rights law. U.S. practice is thus to insist before human rights treaty bodies that the United States will not accept human rights law on absolutist terms (under either liberal or conservative constructions). Rather, the United States asserts it will accept human rights law and treaty body engagements only under terms that allow it: (1) to engage in legitimate self defense where national security is threatened; (2) to be the primary and final interpreter of how international law commitments will be translated into domestic laws and policies; and (3) to ensure that those laws and policies are determined in the first instance by the political branches rather than the courts. These positions do not contradict, but rather are fully consistent with, international human rights law. ${ }^{248}$

What sets modern U.S. human rights policy apart from other states, then, is not its insistence on these well-established legal principles-which other states equally expect to be respected in their relationship with treaty bodiesbut rather its forthrightness and hyper-legalized defense of them in international contexts. ${ }^{249}$ This jurisdictional aggressiveness is often popularly misconstrued as a rejection of human rights law itself, rather than simply a rejection of absolutist constructions of that law. U.S. exceptionalism in this respect may more often be a question of tone and political sensitivity than actual content.

It is here, however, that the mediating nature of the U.S. position is clearest and most consequential from a domestic policy standpoint. While the aggressiveness of U.S. insistence on the primacy of domestic law and the limits of treaty body jurisdiction operates, in many ways, as a liability, it is also a goal: a rhetorical tactic to appease domestic opponents of human rights engagements by making clear that, in actively engaging with human rights treaty bodies, the United States has not surrendered any of its sovereignty, constitutional commitment to a federal form of government, or ability to engage in national defense. It demonstrates that the United States has staked out a firm, legally based position from which it can safely and reliably defend democratic institutions against perceived overreaching by international treaty bodies. With these assurances in place, opponents may be willing to relinquish their "rights cultural" arguments that human rights law conflicts with American constitutional democracy and federal form of government. It may thus open the door to a more sustainable human rights policy at the domestic level over the long term. ${ }^{250}$

Convention: Historic Process, Strong Prospects, and Why the U.S. Should Ratify, Hum. RTS. BRIEF, Winter 2007, at 37,46 .

248. See supra notes 217,240 and accompanying text.

249. That is, the United States is not exceptional in accepting treaty commitments only to the point of political feasibility. It is exceptional only in its forthright and aggressive defense of that policy in international and domestic fora, a defensiveness attributable both to the United States's own hyperlegalized culture and, relatedly, to the fierceness of domestic politics on the underlying issues.

250. It may in fact only be at the domestic level that this door opens, as it is only there that U.S. policy is based on subsidiarity, rather than sovereignty objections. 
Whether this happens, however, will depend on whether U.S. incorporationists see the political opening and take advantage of it.

\section{WHERE FROM HERE?: STRATEGIC INSIGHTS FROM AN INTEREST- MEDIATION PERSPECTIVE ON U.S. HUMAN RIGHTS POLICY}

This Article has thus far sought to offer a new narrative for the "U.S. human rights paradox." That narrative is one which sees U.S. human rights policy not as a static given, structurally or culturally predetermined by "exceptional" features of American democracy (as dominant accounts would have it). Rather, consistent with constitutive legal process theories, it views U.S. human rights policy as a careful and evolving mediation exercise between a variety of instrumentally oriented and ever-adapting interest-group pressures, both at the domestic and foreign policy levels. In its engagement policy, the United States endeavors to maximally accommodate each of these competing interests, consistent with a core set of mediating techniques drawn from foundational international law doctrines.

This interest-management perspective provides a more realistic and empirically plausible account of U.S. human rights engagement policy, I argue, than can dominant accounts sounding in U.S. exceptionalism. Indeed, only an interest-management perspective can explain both the significant expansion that has occurred in U.S. treaty body engagement policy since the 1990 s and the otherwise counterintuitive fact that this expansion not only continued, but accelerated, under conservative Republican control of both the executive branch and Senate in the 2000s, particularly after $9 / 11$. By focusing too heavily and exclusively on conservative minority politics, exceptionalist narratives discount the potential for both of these events.

Yet just as important as a narrative's ability to explain the past or present is its capacity to offer useful insights for the future. In this regard, an interestmediation perspective offers a number of strategic insights for thinking about where U.S. human rights engagement policy is headed. The following three sections consider a number of these insights, particularly as they affect the shape U.S. engagement policy is likely to take over the foreseeable future and how political actors might consider shifting their strategies to gain greater influence over the contours and direction of that policy.

\section{A. The Shape of U.S. Engagement Policy Toward the Future}

Viewed from an interest-management perspective, the shape and growth patterns of U.S. human rights engagement policy over the last two decades follow two key empirical trends. The first involves the expanding influence of foreign policy institutionalists in pushing for greater U.S. treaty body engagement, pulled back by realists only in limited subject-matter "no go" zones. The second involves the gradual diffusion of interests in domestic constituencies opposed to human rights engagement, with a corresponding 
narrowing of issues on which veto politics can effectively operate to block new treaty ratifications.

The net effect of these two trends has been not only U.S. adherence to a growing number of human rights treaties, but also an ever-expanding engagement policy with the treaty bodies charged with their supervision. That engagement policy has nevertheless to date been pursued principally, if not wholly, as a foreign policy objective. This outward-looking orientation is explainable by three mutually reinforcing interest group pressures: the determinative push of institutionalists to engage for the foreign policy benefits it confers, the pull-back insistence by insulationists that raw treaty norms be subject to local democratic deliberation before domestic incorporation, and, perhaps most decisively, the general absence of incorporationist demands for an effective domestic machinery designed to ensure that such democratic deliberation in fact takes place.

Given these underlying interest-group pressures, U.S. human rights engagement policy should then be expected to incorporate the following set of postures over the coming years. Each reflects the continuing application of the sovereignty and subsidiarity-based mediation techniques discussed in Part V to strike a workable and principled balance between competing interests and demands at both the domestic and foreign policy levels.

- The United States will continue to ratify internationally popular human rights treaties, accelerating the process where coordinated domestic lobbying campaigns converge with Democratic majorities in the Senate. Such treaty ratifications will likely consist of the Disability Convention and CEDAW, as first priorities; the American Convention on Human Rights and the CRC, as second priorities; and, finally, the ICESCR. ${ }^{251}$

- These treaties will continue to be accompanied by non-self-execution clauses and other declarations and understandings designed to protect the primacy of domestic political processes in the determination of the scope and contours of domestic human rights protections.

- The United States will continue to participate actively in periodic reporting processes at the U.N. level, as well as through other promotional mechanisms envisioned in U.N., ILO, and OAS law. In so doing, it will take a leading international role in identifying ways to make the process more efficient and less cumbersome for government actors, especially as its reporting obligations continue to grow with the ratification of new treaties.

- The United States will continue to decline to accept the contentious jurisdiction of U.N. treaty bodies.

251. The United States is unlikely to ratify the Migrant Workers Convention, a treaty that, unlike other core U.N. human rights conventions, has not received a high level of support from the international community. 
- All individual contentious complaints of human rights abuse against the United States will instead be processed by the Inter-American Commission on Human Rights, in which the United States will continue to actively and constructively engage. This follows largely from the country's greater familiarity with the system's rules and actors and ability to influence its direction and growth.

- The United States will ratify the American Convention with a view to seating a U.S.-nominated judge on the Inter-American Court of Human Rights. This will be undertaken to better influence the direction of InterAmerican jurisprudence, increasingly important to the United States as more contentious U.S. cases are brought before the Inter-American Commission on Human Rights.

- The United States will not, however, accept the Inter-American Court's jurisdiction over U.S. cases. This policy will continue well into the foreseeable future, at least until the United States has a greater degree of confidence in the court's self-imposed jurisdictional limits and, most decisively, has established a politically based institutional setup for determining the content and scope of effective remedial measures to be taken at the domestic level. ${ }^{252}$

- The United States will continue to resist international supervisory jurisdiction over extraterritorial abuses and those committed in armed conflict, even as it takes measures to prevent such abuses or to respond to them once they occur.

Significantly, given its basis in interest management, U.S. human rights policy should be expected to embrace the above engagement postures irrespective of party control of the White House. Indeed, whether the White House occupant is a liberal Democrat or a conservative Republican, she or he will face the same powerful set of competing interest-group pressures at both the foreign and domestic policy levels, and will need to find a principled yet flexible way to balance and accommodate them in a single policy posture. ${ }^{253}$ In this complex interest-management process, the mediating techniques derived from the principles of subsidiarity and sovereignty should be expected to continue to play a dominant role. This is both because of their firm doctrinal (and hence ideologically neutral) basis in international law and because of their inherent flexibility in responding to new sets of evolving pressures and demands.

252. As a political matter, the United States is also unlikely to accept the contentious jurisdiction of the Court while Canada similarly declines to do so.

253. In an interview given aboard Air Force One, President Obama responded to a question about the release of Guantanamo detainees by asserting that "there is still going to be some balancing that has to be done and some competing interests that are going to have to be addressed." Reassurance on the Economy, and Addressing Afghanistan, N.Y. TiMES, Mar. 8, 2009, at Al. 
It is not, then, stasis that should be expected in U.S. human rights engagement policy, but rather continually evolving and responsive interactions between a wide variety of domestic and international actors, each with vastly different, often conflicting interests. The three predictable constants will be an active attention to the foreign-policy benefits of engagement, a continuing emphasis on the primacy of domestic-level democratic decisionmaking processes, and adherence to a core set of doctrinally anchored mediating techniques designed to effectively mediate the two. The operative question is how incorporationists will fit their own interests into this mediated posture.

\section{B. The Democratic Dangers of Exceptionalist Narrative}

Notably, although incorporationist interests are least represented in U.S. human rights engagement policy, domestic policy incorporationists tend to be the primary promoters of a structurally oriented exceptionalist narrative to the U.S. human rights paradox. Recognition of this fact is important. Indeed, it serves to highlight the deep irony that can result from too heavy a focus by scholars and advocates on the fixedness of the "U.S. human rights paradox," whether that fixedness is attributed to U.S. rights culture, U.S. global hegemony, or "the deep structural reality of American political life." ${ }^{254}$ That irony lies in the fact that civil society, pressed with the constant assertion that the United States does not or will not engage domestically on human rights matters, may stop seeking engagement. In a political democracy, when any group ceases to persistently pursue constructive policy engagement, its interests cannot be expected to be represented in mediated political outcomes.

This political reality is, in fact, directly reflected in today's U.S. human rights engagement policy. As an interest-mediation perspective reveals, that policy has been determined at the intersection of pressures from foreign policy institutionalists, foreign policy realists, and domestic policy insulationists. Notably absent in the equation are domestic policy incorporationists. Although these vital social protagonists have been vigorously active at the local level, working with grassroots communities and effecting local change through a variety of innovative initiatives aimed at local government and general consciousness raising, incorporationists are the first to underscore that they have been least effective in mobilizing their broad base of constituents to engage national policymakers and beltway politics on human rights engagement issues.

Domestic policy incorporationists find themselves in this situation today. Indeed, reflecting a careful accommodation of institutionalist, realist, and insulationist interests, U.S. policy is today directed not to effecting domestic self-reflection, civic discussion, and constructive change within the internal legal order, but rather to demonstrating to other nations the United States's

254. Moravcsik, supra note 2, at 197 (predicting structurally determined stasis in U.S. human rights commitments, and thanking Michael Ignatieff "for posing the question of structure and contingency more sharply"). 
strong commitment to human rights, to international law, and to participation in international institutions.

Within this context, an interest-mediation perspective serves as a civic reminder that U.S. policymaking is neither politically predetermined nor hegemonically undertaken in a political vacuum; it is determined by domestic actors with agency, creativity, and constantly adapting political strategies that interact with each other and their environment as part of a constitutive, contested, constantly evolving process. ${ }^{255}$ To the extent any interest group wishes to exert greater influence over U.S. human rights policy, it must, then, creatively reengage that process. Such reengagement will require an honest assessment of the strategies employed to date and a careful attention to how such strategies impact the equilibria achieved by U.S. mediating techniques.

\section{Rethinking Incorporationist Strategy}

An interest-management perspective on U.S. human rights policy thus powerfully underscores the need to rethink incorporationist strategy. Most importantly, by emphasizing a disaggregated analysis of interest-group pressures and the importance of mediating techniques in striking a principled balance between them, it helps to reveal why U.S. incorporationists have had so little success in having their interests actively accommodated in U.S. human rights policy. That explanation resides not only in incorporationists' relative lack of an organized national engagement strategy but, perhaps even more importantly, in the very nature of the advocacy strategies chosen in pursuit of their incorporationist agenda. Those strategies have tended to be based not on an instrumental embrace of U.S. mediating techniques, but rather on an often aggressive rejection of their very legal validity.

U.S. incorporationist arguments have, in this respect, tended to take three dominant forms: (1) a rejection of "no go" zones; (2) an aggressive denunciation of RUDs, and particularly of the attachment of non-selfexecution declarations to human rights treaties; ${ }^{256}$ and (3) an emphatic insistence on the legal bindingness of international treaty body recommendations. ${ }^{257}$

As this Article has sought to demonstrate, U.S. engagement policy has been based precisely on use of each of these denounced positions-the carving out of "no go" zones, the attachment of non-self-execution

255. See generally W. Michael Reisman, Necessary and Proper: Executive Competence To Interpret Treaties, 15 YALE J. INT'L L. 316, 323-30 (1990) (noting that law is never static; it changes as parties continually shape behavior in accordance with law, in reliance on it, and in the context of multiple factors that shape and limit options).

256. Incorporationists regularly argue that such declarations are inconsistent with the object and purpose of human rights treaties, and thus invalid. See Vienna Convention on the Law of Treaties, supra note 38, art. 19(c). They thus urge removal of RUDs from ratified treaties and the ratification of new treaties without RUDs, particularly non-self-execution clauses.

257. Although the incorporationist community includes a wide range of perspectives, it is the author's experience that these three strategies overwhelmingly dominate incorporationist advocacy discussions on the question of national level engagement policy. These may be distinguished from those targeting purely local initiatives aimed at city or state recognition of human rights treaties. See supra note 186 and accompanying text. 
declarations, and an insistence on the non-bindingness of treaty body recommendations - as a way to promote active U.S. engagement with human rights treaty procedures. In defending these positions, the United States has reliably and reliedly drawn from well-established international law doctrines. Within this context, incorporationist arguments that the United States breaches its international law and treaty commitments by adopting these policies are easily sidelined and dismissed by critics. ${ }^{258}$ By failing to take into account both the strong legal basis for U.S. mediation techniques and the legitimate and important competing values that underlie them, U.S. incorporationists end up speaking a language indiscernible to U.S. policymakers and hence one in which they are unable to effectively communicate their own legitimate policy concerns. The result of this communicative disconnect has been a regular sidelining of incorporationist interests from U.S. engagement policy.

A more productive approach would be not to reject the doctrinally based mediation arguments pursued by the United States in its engagement policy, but rather to find ways to actively embrace them. Indeed, if incorporationist interests are to be maximally taken into account, an interest-mediation perspective suggests that they must be framed to resonate within the doctrinal, jurisdictionally focused policy posture the United States has staked out. Incorporationist strategy would thus profitably look for points of interest convergence or complementarity with the underlying values and priorities of insulationists, institutionalists, and realists, fitting incorporationist narrative into the underlying doctrines that give life to current mediating techniques.

Fortunately, through the complementary duality of their positive and negative dimensions, both the principle of subsidiarity and the doctrine of sovereignty allow for precisely this type of reappropriation. The fact that the United States has to date drawn only on the negative dimensions of the two doctrines reveals the ample and productive terrain upon which incorporationists may strive to build the positive dimensions. Consistent with an interest-management approach, the key will be to find a way to embrace the positive aspects of these doctrines while not rejecting their equally important negative ones.

The challenge for incorporationists toward the future, then, is to visualize how subsidiarity's deference and noninterference doctrines can in fact be used to support and strengthen their own policy positions. Specifically, this will mean rethinking traditional incorporationist objections to classic subsidiarity tools like the non-self-execution doctrine and the nonbindingness of treaty body recommendations, shifting perspective to embrace them as democracy enhancing and deliberation forcing tools-ones which do not block human rights incorporation, but rather actively aid the process of internalizing human rights norms in locally relevant ways.

At the same time, rather than rejecting "no go" zones as a breach of U.S 
treaty obligations, incorporationists might accept the legitimacy of sovereignty-based restrictions on those commitments (where legitimately demonstrated through historical assertion), but then seek to build the positive dimensions of sovereignty. This would mean constructing institutions through which the United States would need to regularly justify its actions to the U.S. population. Through these regular transparency and accountability mechanisms at the domestic level, in which human rights principles would form the framework of analysis and justification, realist insistence on "no go" zones may eventually dissipate. At that point, the United States may decide, in the exercise of its sovereignty, to affirmatively consent to regular treaty body review in those traditional sensitive areas of foreign policy concern.

The broadest and most important area for incorporationist work is, however, at the domestic institutional level. Building the positive dimension of the principle of subsidiarity is paramount in this project. In so doing, incorporationists may in fact seek to appropriate the longstanding arguments invoked by traditional insulationists to shield the U.S. policy environment from the influence of human rights norms and regimes. That is, embracing insulationist arguments that the broad values reflected in human rights treaty commitments must be given locally relevant meaning through democratic deliberation and debate, incorporationists would insist on the construction of a permanent national human rights infrastructure to facilitate regularized domestic debate on the meaning of human rights norms.

This is in fact precisely what the subsidiarity principle is designed to do: to ensure that the heavy lifting of human rights interpretation and implementation occurs at the domestic level, as close as possible to the affected individual. Consistent with this principle, international processes are designed first and foremost to require that monitoring and supervisory processes are established and routinized at the domestic level to resolve human rights complaints locally and to ensure that these are operating effectively and reliably. ${ }^{259}$ International bodies are structured to intervene only when domestic institutions prove ineffective in resolving human rights issues, and then with the primary objective of strengthening local processes through constantly innovating forms of facilitative assistance, or subsidium.

International law's principle of subsidiarity thus provides a particularly useful tool for accommodating the competing interests of domestic policy insulationists and incorporationists. Through its dual and complementary dimensions, it allows the contested struggle over the meaning of rights and their application to concrete, real world situations to take place within domestic control mechanisms, yet ensures that that struggle is aided by the methodological framework and general subsidium of monitoring and implementation mechanisms at the local, state, and federal levels.

259. See, e.g., CESCR, General Comment 1, Report on the Third Session, Annex III, at 87-89, U.N. Doc. E/1989/22, E/C.12/1989/5 (1989) (identifying objectives of periodic reporting, including stimulating and regularizing domestic monitoring, enforcement, and self-appraisal processes, with the broadest civil society participation possible). 
In so doing, the principle of subsidiarity provides an important middle way through the polarizing tensions and cross-talk that currently dominate U.S. discourse on domestic human rights incorporation. This is particularly true with respect to the unhelpful tendency to set "sovereignty and federalism" against "internationalism and human rights." 260 These dueling postures, through their tendency to minimize the important constitutional values and democratic insights offered by the opposing position, tend toward communicative deadlock and heel-digging. ${ }^{261}$ The principle of subsidiarity, by contrast, merges the core democratic insights of both positions. ${ }^{262}$ It values the procedural facilitation of international bodies and national monitoring, while respecting the primacy of localized process in determining appropriate means toward common ends. That is, it sees as its objective the authentic instantiation of human rights values in locally relevant, contingent, and meaningful ways, by local actors--not as cookie-cutter transplants determined and imposed by international experts, as is frequently claimed by those who resist human rights treaty incorporation on sovereignty, federalism or majoritarian grounds. ${ }^{263}$

In sum, until such time as a subsidiarity-based national human rights infrastructure is in fact established through which broad and regularized democratic deliberation on the meaning of rights protections can locally take place, the United States should not be permitted to claim legitimate free resort to the noninterference dimensions of that doctrine. The United States's heavy reliance on subsidiarity's negative dimension as the basis of its engagement policy may, in this way, effectively be turned from an insulationist's shield into an incorporationist's sword.

260. This discourse, which extends over an enormous literature, is in many ways succinctly encapsulated in the popular-media exchange between Peter Spiro, Jack Goldsmith, and Curtis Bradley in Foreign Affairs, in which "sovereignty" and "internationalism" are antagonized. See Peter J. Spiro, The New Sovereigntists: American Exceptionalism and Its False Prophets, FOREIGN AFF., Nov.-Dec. 2000, at 9,9 (describing sovereigntists as "insulationist" and "anti-international[]"); Curtis A. Bradley \& Jack L. Goldsmith, Letter to the Editor, My Prerogative, FoREIGN AFF., Mar.-Apr. 2001, at 188, 188-89 (rejecting Spiro's "unalloyed internationalism" as ignoring the importance of state consent); Peter J. Spiro, Postscript, What Happened to the "New Sovereigntism"?, ForeIGN AFF., July 28, 2004, http://www.foreignaffairs.com/articles/64224/peter-j-spiro/what-happened-to-the-new-sovereigntism (predicting that the United States will finally be forced to "bend to international norms" after the Iraq war debacle); see also Bradley, supra note 229, at 461 (concluding that the U.S. government must "make a choice": human rights treaties or American federalism).

261. See generally Bradley \& Goldsmith, supra note 258.

262. The constitutive relationship between democracy, subsidiarity, and human rights has been initially explored in Dinah Shelton, Subsidiarity, Democracy and Human Rights, in BroadeNING THE FroNTIERS OF HUMAN RIGHTS: ESSAYS IN HONOUR OF ASBJORN EIDE 43 (Donna Gomien ed., 1993).

263. See, e.g., Jack Goldsmith, Should International Human Rights Law Trump U.S. Domestic Law?, 1 CHI. J. INT'L L. 327, 338-39 (2000). As Professor Carozza has underscored, "A subsidiarityoriented understanding of human rights and international law does not care to ask whether 'state sovereignty' must either resist or give way to international harmonization and intervention but, instead, whether the good that human rights aim at realizing can be accomplished at the local level, and if not, what assistance is necessary from a more comprehensive association to enable the smaller unit to realize its role." Carozza, supra note 15 , at 66. 


\section{HONORING SUBSIDIARITY DOCTRINE IN FULL: FROM INTERNATIONAL DEFENSE TO DOMESTIC CHALLENGE}

From a democracy standpoint, the most notable aspect of U.S. treaty body engagement policy today is indeed precisely its lack of any explicit goal of strengthening domestic human rights protection. To the contrary, the U.S. position has been that it already has strong domestic rights protections and that, beyond certain modifications determined to be necessary before ratification, it does not need to make additional internal changes in its laws and policies. ${ }^{264}$ Accordingly, even as the United States recognizes before international bodies that it is not perfect, that it has gaps to fill, and that human rights fulfillment is evolutionary, ${ }^{265}$ there is currently no institutional mechanism in place to systematically gather and process information from domestic actors on how the United States could improve its human rights protections. Likewise, while the United States prepares reports for submission to treaty bodies with a high degree of comprehension and detail, complying strictly with the technical aspects of its reporting requirements, it lacks any formal institutional mechanism to systematically receive the inputs of civil society into that process, to circulate outputs, to debrief the nation on its findings, or to encourage national reflection on how identified deficiencies might be remedied.

It is here that the central puzzle of U.S. human rights policy is located: how can such overt lack of institutional attention to facilitating domestic deliberative human rights processes be reconciled with the nation's formal insistence, as part of its treaty body engagement policy, on the secondary or subsidiary role of international treaty bodies and the primacy of domestic processes in the interpretation and protection of international human rights treaty norms? As I have sought to argue, the disconnect lies in the United States's selective and partial use of the tools of international human rights law's subsidiarity principle to mediate the conflicting pressures faced from dominant interest groups.

The problem is that the structural integrity of human rights law cannot endure subsidiarity's expedient fracture into constituent halves; it is constituted irreversibly of both the noninterference principle and that of intervention or assistance, each of which serves as a structural check on the other in the service of human dignity. Indeed, just as subsidiarity's negative dimension guards against drift into centralized bureaucracy or authoritarianism, so too does its positive dimension stand as a bulwark against collapse into simple devolution or pure unchecked discretion. By invoking only subsidiarity's negative side and, then, only vis-à-vis the U.S. relationship with international treaty bodies-not within the U.S. body politic itself-the United States upsets first principles of international human rights law, reimagining it as a simple exercise in local devolution. 
This partial recognition accounts for why supervisory treaty body concern is so often raised in relation to U.S. reliance on certain doctrinal tools emanating from subsidiarity's negative dimension (such as the non-selfexecution doctrine), despite such tools' solid foundation in international human rights law and broad parallel use by other nations. ${ }^{266}$ Indeed, that concern arises not in relation to the tools themselves, which, in conjunction with subsidiarity-based monitoring mechanisms, are fully sanctioned by international law. Rather, it relates to their regular employ in the absence of effectively functioning domestic monitoring and supervisory mechanisms that reflect subsidiarity's affirmative dimension. Thus, for instance, while both the United States and Canada apply the non-self-execution doctrine in implementing human rights treaties, international concern tends to be expressed with respect to the former only. This is because Canada employs the doctrine not in isolation, but in symmetry with an integrated system of national, provincial, and local human rights institutions. ${ }^{267}$ These institutions are mandated to serve in a subsidiarity capacity-internalizing and domesticating human rights values in locally relevant, democratically sanctioned, and indigenized ways, as close as possible to the individual, yet within a supportive national structure. ${ }^{268}$

A fuller recognition of the comprehensive nature of subsidiarity thus illuminates the central U.S. human rights challenge for the future: how to give substance to the affirmative aspects of subsidiarity in national human rights policy, while continuing to honor and respect the negative aspects. Indeed, this appears to be the path most capable of effectively accommodating the key vital tensions in domestic-level U.S. human rights policy.

The question is: how do we structure this? International human rights law, in function of its basis in subsidiarity doctrine, tends to offer an institutional outline, even while recognizing the wide variety of institutional arrangements states adopt to govern themselves. ${ }^{269}$ At the national level, two general levels of institutional supervisory arrangements are called for: one for national implementation of human rights treaty commitments, the other for national monitoring of those commitments. Both should be established in the United States as a matter of priority. ${ }^{270}$

The following two Sections consider each of these national-level institutional arrangements as they might profitably be established in the United States. Each of these arrangements is nevertheless fully replicable at

266. See supra note 235 .

267. For an excellent discussion, see Koren L. Bell, Note, From Laggard to Leader: Canadian Lessons on a Role for U.S. States in Making and Implementing Human Rights Treaties, 5 YALE HuM. RTS. \& DEV. L.J. 255 (2002).

268. See id.

269. See, e.g., Disability Convention, supra note 40 , art. 33 (recognizing need of states parties to establish national implementation mechanisms "in accordance with their system of organization" and national monitoring mechanisms "in accordance with their legal and administrative systems").

270. Drawing expressly on the proposals in this Article, as well as the recommendations of a Blueprint Advisory Group, a formal proposal to establish both national mechanisms was submitted to the Obama administration in October 2008. See CATHERINE POWELL, AM. CONSTITUTION SOC'Y FOR Law \& Politics, Human Rights at Home: A Domestic Policy Blueprint for the New ADMINISTRATION (2008), available at http://www.acslaw.org/files/C\%20Powell\%20Blueprint.pdf. 
"lower" levels of political organization-by states, counties, cities, and towns. Indeed, such institutional layering of supervisory authority is core to subsidiarity's premise, ensuring that decisionmaking and monitoring occurs as close as possible to the affected individual.

\section{A. National Office on Human Rights Implementation and Interagency Coordination Body}

The first national institutional arrangement required by an effective subsidiarity-based regime is an executive branch "focal point" on implementation. ${ }^{271}$ Ideally in the form of a National Office on Human Rights Implementation, such a focal point would be dedicated to taking care that the nation's international human rights treaty undertakings are appropriately implemented in the domestic jurisdiction. ${ }^{272}$ As the national face for human rights implementation efforts, the focal point should be based in the Executive Office of the President and led by a person of recognized competence and expertise in the field of human rights. That individual, through the National Office, would be responsible for overseeing national efforts on human rights matters.

Importantly, as an orchestrating body, its purpose would not be to take over the administrative functions of other agencies, nor to be responsible for implementing programs or policies, outside those regarding transparency, capacity-building, human rights training, and small grants programs for innovative local human rights initiatives. Rather, consistent with subsidiarity, it would be dedicated to taking care that the nation's human rights commitments were being appropriately implemented in the domestic jurisdiction, through each of the nation's many competent departments and agencies. To this end, it would be assisted at the federal level by a coordination mechanism composed of a senior-level representative from each of the major agencies and departments of government. ${ }^{273}$ Each member would be personally responsible for overseeing, coordinating and reporting on human rights mainstreaming efforts in her department, as well as responding to agency-related complaints of human rights abuse. The National Office on Human Rights would act as a backstop on these efforts, providing coordination, a mechanism for the sharing of best and worst practices, encouragement, and advice. To ensure this essential orchestrating role, the

271. There is an increasing emphasis in international law and development theory on ensuring government focal points. Such focal points generally take the shape of a dedicated office within government or other policy-coordinating body. See, e.g., Disability Convention, supra note 40, ant. 33(1) ("States Parties ... shall designate one or more focal points within government for matters relating to the implementation of the present Convention ....").

272. The U.S. Constitution invests the President with the power and duty to "take Care that the Laws be faithfully executed." U.S. CoNST. art. II, $\S 3$. This undertaking includes enforcement of treaties, which form part of the "supreme Law of the Land." Id. art. VI.

273. See Disability Convention, supra note 40, art. 33(1) ("States Parties . . . shall give due consideration to the establishment or designation of a coordination mechanism within government to facilitate related action in different sectors and at different levels."). 
coordination mechanism should ideally be chaired by the national focal point on human rights matters.

While the United States lacks any executive branch focal point for domestic-level human rights treaty implementation, it has formally established a coordination mechanism. Envisioned by President Clinton's 1998 Executive Order 13,107, and reorganized under President Bush's 2001 National Security Presidential Directive, ${ }^{274}$ that mechanism must be revitalized and given life through new infusions of personnel, resources, and specific human rights mainstreaming mandates, with appropriate corresponding tools of transparency and sanction where deficiencies are identified in agency or department conduct.

It is essential, however, that such a revitalized coordination mechanism be accompanied by a National Office on Human Rights Implementation. Without a centralized, permanent, and dedicated focal point to orchestrate the human rights mainstreaming work of agency and department heads, the coordination mechanism alone will not be maximally effective. This has in fact been the experience of the current Policy Coordination Committee (PCC) on Democracy, Human Rights, and International Operations, which has not functioned other than in an ad hoc fashion. This experience owes in large part to the absence of a dedicated executive focal point that has human rights treaty implementation as its exclusive mandate and area of expertise. Rather, the PCC has been headed by the Assistant to the President for National Security Affairs, for which domestic level human rights treaty implementation may be neither a priority nor interest.

A National Office on Human Rights Implementation would thus work with a coordination mechanism to ensure that each of the critical functions expressed in Executive Order 13,107 are carried out by the appropriate authority or authorities, including the following:

- responding to inquiries, requests for information, and complaints about violations of human rights obligations that fall within each authority's areas of responsibility;

- coordinating the preparation of treaty compliance reports to the United Nations, the OAS, and other international organizations;

- coordinating responses to contentious complaints lodged with the same organizations;

- overseeing a review of all proposed legislation to ensure its conformity with international human rights obligations;

- ensuring that plans for public outreach and education on human rights provisions in treaty-based and domestic law are broadly undertaken; and 
- ensuring that all nontrivial complaints or allegations of inconsistency with or breach of international human rights obligations are reviewed to determine whether any modifications to U.S. practice or laws are in order. $^{275}$

In addition to these competences, the National Office on Human Rights Implementation would likewise have the important mandate to report to Congress and to the nation annually on national human rights progress and to make recommendations on new legislation or policies that might periodically be required on the basis of information received. In this way, Congress would be regularly informed of human rights implementation measures taken throughout the nation and could supplement efforts where gaps in coverage were identified or new forms of spending were required.

The National Office would also, however, play an important facilitation role with respect to the human rights implementation initiatives undertaken by state and local authorities. It could collect information, share best practices, provide publicity, shine a national spotlight on abusive situations, and promote the scaling up of the nation's most successful local experiments with human rights implementation. The Office would act as a centralizing repository for information generated from a variety of programs, agencies, and private sector sources on national human rights achievement, problem areas, and setbacks, and could be held to political account for failures to supervise or intervene where systemic or gross abuses were uncovered.

In short, the National Office on Human Rights Implementation would serve as the nation's focal point for ensuring that federal, state, local, and private entities were adequately supported and incentivized to implement effective and appropriate human rights policies for themselves, as close as possible to affected individuals. In this way, its mandate would be to help obviate the need for individuals to seek human rights protections and enforcement at international or even national levels. Rather, consistent with the positive dimensions of subsidiarity, it would function to ensure those protections were provided effectively at the immediate site of abuse.

\section{B. United States Commission on Human Rights}

Yet, an implementation mechanism alone is not enough to ensure an effective national system of subsidiarity-based protection for human rights. An executive focal point must be accompanied by a fully institutionalized national-level monitoring framework to ensure that all individuals have the ability to participate in national-level scrutiny and public oversight of U.S. human rights implementation commitments. ${ }^{276}$ Such a body, ideally in the

275. Exec. Order No. 13,107, supra note 54, §§ 2-4.

276. See, e.g., Disability Convention, supra note 40, art. 33.2 ("States Parties shall . . maintain, strengthen, designate or establish within the State Party, a framework, including one or more independent mechanisms, as appropriate, to promote, protect and monitor implementation of the present Convention. When designating or establishing such a mechanism, States Parties shall take into account 
form of a United States Commission on Human Rights, would serve as an independent check on implementation failures, providing a forum through which individuals could report abuses and seek political or quasi-judicial address at the domestic level, before needing to recur to international treaty bodies.

To be maximally effective, it should be instituted and financed by government, but functionally independent of the political branches, consistent with the Paris Principles. ${ }^{277}$ Most countries honor this function by creating a national human rights commission or ombudsperson's office, bodies that can be further replicated within subnational political units, as close to the individual as necessary. ${ }^{278}$

Many U.S. states and cities do in fact have bodies called "human rights commissions" or "human relations commissions." ${ }^{279}$ Few, however, interpret their mandate as extending beyond investigating complaints of discrimination. ${ }^{280}$ A U.S. Commission on Human Rights would serve to encourage states and localities to broaden their own mandates to encompass the full field of rights recognized in the Universal Declaration of Human Rights and in the treaties ratified by the United States. A subsidiarity-based relationship would then be engaged in which the national body would serve to support the human rights protection and promotion activities of more local commissions, ensuring that protection efforts are provided throughout the nation's diverse communities.

Within this subsidiarity orientation, the U.S. Human Rights Commission would have a broad promotional and protective mandate. ${ }^{281}$ It would be able to issue relevant reports and guidelines on rights-respecting behavior by distinct social actors. These would include nonbinding guidelines or guiding principles on appropriate conduct in prisons, police stations, administrative agencies, and other fora in which human rights abuses frequently occur, as well as the power and responsibility to make regular (nonbinding) recommendations to all relevant stakeholders, including particularly Congress, executive agencies and departments, and the legislatures of the many states. Such recommendations would be offered in a constructive spirit of

the principles relating to the status and functioning of national institutions for protection and promotion of human rights.").

277. National Institutions for the Promotion and Protection of Human Rights ("The Paris Principles"), G.A. Res. 48/134, U.N. Doc. A/Res/48/134 (Mar. 4, 1994) [hereinafter Paris Principles].

278. The International Coordinating Committee of National Human Rights Institutions counts over one hundred National Human Rights Institutions worldwide. Ad Hoc Comm. on a Comprehensive and Integral Int'l Convention on the Prot. and Promotion of the Rights and Dignity of Persons with Disabilities, National Institutional Frameworks and Human Rights of Persons with Disabilities, at 2 n.4, U.N. Doc. A/AC.265/2006/CRP.5 (Aug. 14, 2006).

279. There reportedly are only three states-Alabama, Arkansas, and Mississippi-that do not have any form of a state or local human rights or human relations commission. See Kenneth L. Saunders \& Hyo Eun (April) Bang, A Historical Perspective on U.S. Human Rights Commissions 13 (Harvard Univ. John F. Kennedy Sch. of Gov't, Executive Session on Human Rights Comm'ns and Criminal Justice, Paper No. 3, 2007), available at http://www.hrccj.org/pdfs/history_of_hrc.pdf.

280. The U.S. Commission on Civil Rights has a similarly limited mandate.

281. Paris Principles, supra note 277, Annex, Part A, para. 2 ("A national institution shall be given as broad a mandate as possible, which shall be clearly set forth in a constitutional or legislative text, specifying its composition and its sphere of competence."). 
cooperation, indicating areas of concern and offering assistance in identifying the most effective measures of response in consultation with affected citizens and local or national authorities.

A national human rights commission would also receive complaints from individuals about alleged human rights violations, initiate investigations, offer mediation services, arrive at findings, and issue recommendations to the parties or to relevant local authorities. ${ }^{282}$ It would be competent to hold nationwide thematic hearings on distinct human rights issues, especially where common themes emerged from state and local hearings, and engage in independent monitoring of national human rights conditions through a variety of means, including investigations, inquiries, and surveys. In this respect, it might gather statistics from local and state human rights commissions on the numbers and types of issues and complaints they were addressing, and ensure the broad availability of human rights documents and materials. It could thus serve as an important conduit for receiving and processing the results of localized discussions, policies, and experiments around the nation, with a view to discussing and sharing them among a national audience.

In this respect, a U.S. Commission on Human Rights would be selfconsciously based on the principle of subsidiarity, ensuring that its interventions were always aimed at supporting local decisionmaking and implementation processes. Its work would be directed to supporting localism, states' rights, and the vital experimentation they foster, while also serving in a capacity to illuminate problematic areas where national policy intervention may be necessary in function of subsidiarity's positive assistive aspect.

Finally, a U.S. monitoring body would engage in regular human rights education and training programs. Such programs would be directed both to a national audience and to human rights education in particular contexts, such as schools, prisons, and the varying layers of local, state, and federal bureaucracies. It would assist local human rights commissions and private actors as well in facilitating their own human rights education or training campaigns. The Paris Principles in fact explicitly affirm that NHRIs "shall, inter alia, have the following responsibilities":

To assist in the formulation of programs for the teaching of, and research into, human rights and to take part in their execution in schools, universities and professional circles;

To publicize human rights and efforts to combat all forms of discrimination ... by increasing public awareness, especially through information and education and by making use of all press organs. ${ }^{283}$

In this way, a U.S. Human Rights Commission would ensure that individuals throughout the United States both knew their rights and knew how those rights could be protected. Most importantly, however, it would ensure that effective rights protections were afforded at the local level, at the

282. Cf. id. Part D (listing additional principles conceming the status of commissions with quasi-jurisdictional competence).

283. Id. $\ 3,3(\mathrm{f})-3(\mathrm{~g})$ (emphasis added). 
immediate site of abuse, without having to resort to international subsidiaritybased fora of human rights protection for additional assistance.

\section{CONCLUSION: INSTITUTIONALIZING SUBSIDIARITY}

In his statement before the 1993 World Conference on Human Rights, U.S. Secretary of State Warren Christopher affirmed that "[i]n the battle for democracy and human rights, words matter, but what we do matters much more." 284 This continues to be the slogan of the U.S. State Department in its engagement policy with international human rights treaty bodies. That is, the United States engages such bodies in a procedurally exacting, substantively responsive, and high-level way, with the aim of setting an example for other states in deepening their own sovereign engagements with human rights treaty body supervision.

Yet what the United States in fact does in its engagement policy constitutes only half of what it seeks to encourage other states to do. The United States does not wish to encourage other states to use treaty ratification primarily as a foreign policy tool, formally preparing and presenting reports, answering questions, and then leaving the process in Geneva, away from the critical reflection of domestic constituencies. Such a process would serve no useful domestic-level purpose, either in terms of strengthening democratic institutions or enhancing human dignity. To the contrary, the United States aims to use its influence to encourage the world's governments to bring those international processes and commitments home, to discuss them with civil society, to monitor its own human rights progress, and to work to correct areas of deficiency through local innovation, transparency, and corrective experimentation. That is, in its foreign policy engagements, the United States aims to ensure that international supervision truly serves its intended subsidiary purpose: to accompany and impel forward domestic processes of human rights monitoring, supervision, and remediation at national, state, and local levels.

In this respect, if the United States genuinely wishes to set a positive, constructive example for other states, it must-as Secretary Christopher underscored-not only talk-the-talk, but walk-the-walk, demonstrating through self-directed action its commitment to domestic human rights processes. This cannot include engagement with the mere formalisms of international treaty obligations, using them to shield domestic processes from the influence of treaty body engagement. Rather, it must include engagement with the substance and spirit of them. This means institutionalizing domestic processes for using treaty body engagement as the impetus for a regular conversation and self-analysis of how well we are in fact standing up to human rights commitments, as we understand them in our complex and diverse communities and in the concrete contexts in which we live. It means monitoring national-level statistics and collecting regular information from the states with respect to each recognized right, regularly listening to citizens 
about the ways in which they feel their rights are or are not being addressed, actively considering their proposals for effective solutions, and systematically analyzing complaints of abuse and what remedies are in place to address them. Within this process, the inputs of international actors and comparative national experience can be highly instructive, even as they are never determinative for the precise contours of U.S. policy. That is, human rights engagement is not only or even principally about having a conversation at the international level; it is about starting and sustaining a domestic conversation, one that begins at the smallest and most local of places and works its way up to town, state, and federal authorities, within a national facilitative structure.

A U.S. treaty body engagement policy structured in this way-with the focus on domestic processes and responsive accountability to local needswould go a long way toward transforming U.S. human rights policy from a noted example of paradox for the rest of the world, to a genuine model of how human rights law and international treaty body engagement can be used, through subsidiarity principles, to deepen democratic processes, strengthen civil society participation, and internalize human rights protections in locally relevant, factually responsive, and genuinely meaningful ways. 